\title{
RELAÇÕES DE PREÇO NO MERCADO DE ALGODÃO EM PLUMA E DESENVOLVIMENTO DO MERCADO FUTURO DE ALGODÃO NO BRASIL
}

\section{THEREZA CHRISTINA PIPPA ROCHELLE}

Engenheiro Agrônomo

Orientador: Prof. Dr. JOAQUIM BENTO DE SOUZA FERREIRA F'

Tese apresentada à Escola Superior de Agricultura "Luiz de Queiroz", Universidade de São Paulo, para obtenção do título de Doutor em Ciências, Área de Concentração: Economia Aplicada.

PIRACICABA

Estado de São Paulo - Brasil

Outubro - 2000 
Dados Internacionais de Catalogação na Publicaçāo (CIP) DIVISĀO DE BIBLIOTECA E DOCUMENTAÇĀO - Campus "Luiz de Queiroz"/USP

\section{Rochelle, Thereza Christina Pippa}

Relaçōes de preço no mercado de algodão em pluma e desenvolvimento do mercado futuro de algodão no Brasil / Thereza Christina Pippa Rochelle. - - Piracicaba, 2000.

$163 \mathrm{p}$.

Tese (doutorado) - Escola Superior de Agricultura Luiz de Queiroz, 2000.

Bibliografia.

1. Algodão 2. Análise de regressão 3. Economia agrícola 4. Mercado futuro 5. Preço agricola I. Tímulo

CDD 338.13351

Termitua a copia total ou parcial deste documento, desde que citada a foute - 0 autor 
Aos meus pais, com carinho e gratidão, ofereço.

Para Alexandro, com amor, dedico. 


\section{Agradecimentos}

Ao Professor Doutor Joaquim Bento de Souza Ferreira Filho, pela orientação primorosa e constante incentivo durante a elaboração deste estudo.

Ao corpo docente do Departamento de Economia, Administração e Sociologia da Escola Superior de Agricultura "Luiz de Queiroz" (DEAS/ESALQ), pelos preciosos ensinamentos adquiridos durante o Curso de Doutorado.

Ao Professor Dr. Geraldo Sant'Ana de Camargo Barros, à Professora Dra. Mírian Rumenos Piedade Bacchi e ao Professor Dr. Pedro V. Marques, pela participação e valiosas sugestões em etapas anteriores à finalização desta pesquisa, as quais muito contribuíram para o aperfeiçoamento da mesma.

Ao Centro de Estudos Avançados em Economia Aplicada da Fundação de Estudos Agrários "Luiz de Queiroz" (CEPEA/FEALQ), à Companhia de Nacional de Abastecimento (CONAB), à Secretaria da Receita Federal - Coordenação de Estatísticas Econômico-Tributárias Divisão de Estatísticas do Comércio Exterior (SRF - COEST/DIVEX) e ao Banco Central do Brasil, pela atenção e presteza no fornecimento de dados utilizados nesta pesquisa.

Aos Senhores Fernando F. Lyra Porto e Henrique Fracalanza, pela gentileza e solicitude em esclarecer aspectos operacionais do mercado físico de algodão em pluma, que muito auxiliaram na condução deste estudo. 
Aos funcionários do DEAS, em especial à Srta. Maria Aparecida Maieli Travalini, pela atenção e cooperação durante todo o Curso de Doutorado.

À CAPES, pela Bolsa de Estudos concedida durante o Curso de Doutorado.

Aos colegas do Curso de Doutorado, principalmente ao amigo Eduardo Luís L. de Sousa, e a todas as demais pessoas que, direta ou indiretamente, contribuíram para a realização deste trabalho. 


\section{SUMÁRIO}

LISTA DE FIGURAS........................................ ix

LISTA DE TABELAS....................................... xi

RESUMO..................................................... xiii

SUMMARY ............................................... xvi

1 INTRODUÇÃO E JUSTIFICATIVA......................... 1

$1.1 \mathrm{O}$ problema e sua importância......................... 3

1.2 Objetivos................................................ 6

1.3 Hipóteses.................................................. 7

2 PANORAMA DO MERCADO MUNDIAL DE ALGODÃO EM PLUMA...................................... 8

3 O MERCADO BRASILEIRO DE ALGODÃO EM PLUMA.................................................... 12

3.1 Produção de algodão em pluma no Brasil.......... 12

3.2 Aspectos relevantes da comercialização de algodão no Brasil............................................. 16

3.3 As importações brasileiras de algodão em pluma..........................................................

$3.4 \mathrm{O}$ destino das importações brasileiras de algodão em pluma.................................................... 33

4 OS MERCADOS FUTUROS.............................. $\quad 36$

4.1 A evolução dos mercados futuros no mundo........ 36 
4.2 A evolução dos mercados futuros no Brasil......... 40

4.3 O mercado futuro de algodão em pluma............. $\quad 49$

5 REVISĀO DE LITERATURA................................. 54

6 CONSIDERAÇŌES TEÓRICAS............................ 60

7 MÉTODOS.................................................... 66

7.1 Estimação da razão ótima de hedge................... 66

7.2 Testes de raiz unitária.................................... 71

7.3 Análise da relação entre as importações financiadas de algodão em pluma e a arbitragem das taxas de juros nos mercados interno e externo... $\quad 80$

7.4 Análise de co-integração entre os preços do algodão em pluma nos mercados interno e externo.... 84 8 RESULTADOS E DISCUSSĀO............................. 91

8.1 Resultados das estimações da razão ótima de hedge............................................................ 91

8.1.1 Resultados dos testes de raiz unitária nas sêries de preços................................................ 91

8.1.2 Resultados dos testes para verificar a hipótese de mercado futuro eficiente............................... 95

8.1.3 Resultados das estimativas das razões ótimas de hedge.

8.2 Resultados da análise da relação entre as importações financiadas de algodão em pluma e a arbitragem das taxa de juros nos mercados interno e externo

8.3 Resultados da análise de co-integração entre os preços do algodão em pluma nos mercados interno e

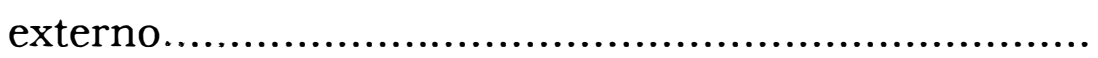


8.3.1 Resultados da determinação da ordem de integração das séries de preços............................. 118

8.3.2 Resultados da estimativa da relação de equilíbrio de longo prazo...................................... 121

8.3.3 Resultados da estimativa do MCE.................... 124

9 CONCLUSŌES................................................ 128

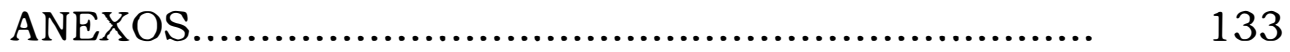

REFERÊNCIAS BIBLIOGRÁFICAS......................... 143

APÊNDICES................................................ 151 


\section{LISTA DE FIGURAS}

Página

1 Evolução mensal dos índices Cotlook A e B, do preço futuro do algodão em pluma na NYCE e do preço do algodão em pluma no Brasil - 1985 a 1999..

2 Área plantada, produção e produtividade da cultura de algodão no Brasil - 1990 a 2000..............

3 Fluxo genérico da produção de têxteis no Brasil....

4 Valor CIF e peso líquido das importações brasileiras de algodão em pluma - 1992 a 1999 ........

5 Valor CIF das importações brasileiras de algodão em pluma, segundo a forma de pagamento - 1992 a 1999

6 Evolução das taxas de juros nos mercados interno e externo e do índice de taxa real de câmbio - 1993 a 1999

7 Percentual das importações brasileiras de algodão em pluma destinado a cada região, segundo o porto de entrada - 1992 a 1999

8 Volume anual de contratos futuros negociados na

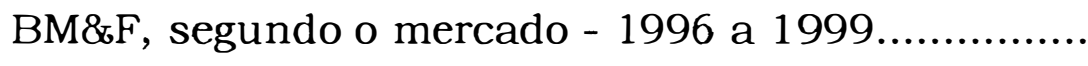

9 Volume anual de contratos futuros agropecuários negociados na BM\&F - 1996 a 1999...................... 
10 Evolução da participação percentual de cada produto no total de agropecuários negociados na BM\&F - 1996 a 1999............................................

11 Volume de contratos futuros de algodão em pluma negociados na BM\&F - Novembro/1996 a Dezembro/ 1999.................................................

12 Evolução diária do Indicador ESALQ/BM\&F, preços futuros da BM\&F e NYCE e taxa de câmbio (R\$/US\$) - 22/nov/ 1996 a 15/dez/1999................

13 Médias semanais do Indipluma ESALQ/BM\&F e dos preços futuros na BM\&F - Jan./1997 a Dez./ 1999.....................................................

14 Médias semanais do Indipluma ESALQ/BM\&F e dos preços futuros na NYCE - Jan./1997 a Dez./ 1999.........................................................

15 Valor CIF das importações brasileiras financiadas de algodão em pluma e diferença entre as taxas de juros nos mercados interno e externo $\left(d_{1}\right)$ - Janeiro/ 1996 a Dezembro/1999

16 Valor CIF das importações brasileiras financiadas de algodão em pluma e diferença entre as taxas reais de juros nos mercados interno e externo $\left(\mathrm{d}_{2}\right)$ - Janeiro/1996 a Dezembro/1999........ 


\section{LISTA DE TABELAS}

Página

1 Importações brasileiras de algodão em pluma,

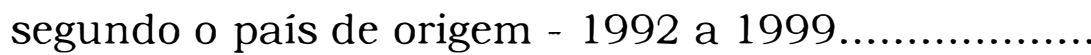

2 Resultados do AIC e SC para as séries de preços a serem utilizadas na estimação da razão ótima de hedge para o contrato futuro da BM $\& \mathrm{~F} . . . . . . . . . . . . . . .$.

3 Resultados do AIC e SC para as séries de preços a serem utilizadas na estimação da razão ótima de hedge para o contrato futuro da NYCE...................

4 Resultados da identificação dos elementos deterministicos e testes de raiz unitária nas séries de preços à vista (Indipluma ESALQ/BM\&F) e futuros da BM\&F e NYCE em nivel................................ 5 Resultados dos testes de raiz unitária para as séries de preços à vista (Indipluma ESALQ/BM\&F) e futuros da BM\&F e NYCE na primeira diferença....... 6 Resultados da verificação da hipótese de mercado futuro eficiente para os preços futuros da BM\&F e

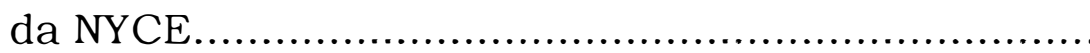

7 Resultados das estimativas das razões ótimas de hedge para os contratos futuros de algodão em pluma da BM\&F e da NYCE........................... 
8 Resultados das estimativas das razões ótimas de hedge para os contratos futuros de algodão em pluma da BM\&F e NYCE, excluindo-se o ano de 1999

9 Resultados dos testes de raiz unitária com mudança estrutural para as séries dos diferencias $d_{1}$ 108 10 Resultados da identificação dos elementos determinísticos e testes de raiz unitária nas séries dos diferencias $d_{2}$ 108

11 Resultados da identificação dos elementos determinísticos e testes de raiz unitária para as séries das importações financiadas de algodão em pluma.

12 Resultados da identificação dos elementos determinísticos e testes de raiz unitária nas séries de preço do algodão em pluma nos mercados interno e externo.

13 Resultados dos testes de raiz unitária para as séries de preço do algodão em pluma (na primeira diferença) nos mercados interno e externo

14 Resultado da estimativa da relação de longo prazo entre o preço do algodão em pluma no Brasil e o Cotlook A.

15 Resultado do teste para verificar a estacionariedade dos resíduos estimados na relação

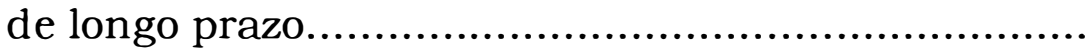

16 Resultado da estimativa do MCE para as variáveis preço do algodão em pluma no Brasil e Cotlook A Index. 


\title{
RELAÇÕES DE PREÇO NO MERCADO DE ALGODÃO EM PLUMA E DESENVOLVIMENTO DO MERCADO FUTURO DE ALGODÃO NO BRASIL
}

\author{
Aluna: THEREZA CHRISTINA PIPPA ROCHELLE \\ Orientador: Prof. Dr. JOAQUIM BENTO DE SOUZA FERREIRA F
}

\section{RESUMO}

O presente estudo foi elaborado com a finalidade de analisar dois fatores que afetam o potencial de desenvolvimento do mercado futuro de algodão no Brasil: a) a utilização do contrato futuro de algodão em pluma da New York Cotton Exchange (NYCE) para hedging de preço do algodão em pluma brasileiro e b) a possibilidade de as importações financiadas dessa fibra estarem vinculadas à arbitragem das taxas de juros nos mercados interno e externo. Adicionalmente, foi conduzida uma análise para verificar a integração entre os mercados doméstico e internacional de algodão, após o processo de abertura comercial no Brasil.

Para comparar os contratos futuros de algodão em pluma da Bolsa de Mercadorias \& Futuros (BM\&F) e da NYCE como instrumentos de administração de risco de preço, procedeu-se à estimação da razão ótima e ao cálculo da efetividade do hedge. Utilizando preços referentes 
ao periodo de janeiro de 1997 a dezembro de 1999, a estimativa da razão ótima de hedge para o contrato futuro da BM\&F resultou em $40,42 \%$, sendo a efetividade da operação igual a $22,5 \%$. Para o contrato futuro da NYCE, o coeficiente estimado apresentou-se não significativo.

Esses resultados mostram que o contrato futuro de algodão em pluma da BM\&F tem sido um instrumento efetivo de administração de risco de preço para o produto brasileiro, ainda que a efetividade da operação não seja elevada. O mesmo não pode ser afirmado em relação ao contrato futuro da NYCE. Nesse contexto, existe um potencial ainda não efetivado para o desenvolvimento do mercado futuro de algodão no Brasil.

Foram realizadas análises de regressão entre as importações financiadas de algodão em pluma e o diferencial das taxas de juros interna e externa, a fim de verificar a existência de uma relação entre essas variáveis. Em todos os modelos estimados, o coeficiente da variável independente defasada (diferencial entre as taxas de juros) apresentou-se estatisticamente não significativo.

Possivelmente, tais resultados refletem a inexistência de uma relação entre essas variáveis ou a existência de uma relação que não pôde ser identificada através dos métodos econométricos empregados neste estudo. Essa segunda possibilidade deve-se ao comportamento das taxas de juros e importações financiadas, condicionado por muitas outras variáveis econômicas e pelas características operacionais das transações que as envolvem.

Apesar dos resultados obtidos, parece razoável afirmar que enquanto persistirem as condições favoráveis de taxas de juros e prazos de pagamento oferecidos no mercado internacional, deverá haver algodão sendo importado. A possibilidade de obter vantagens ou ganhos financeiros com as importações financiadas pode estar fazendo com que 
os importadores não considerem importante o risco de preço e a necessidade de hedge para a matéria-prima adquirida externamente. Tal situação estaria afetando negativamente o potencial de desenvolvimento do mercado futuro de algodão no Brasil.

Contudo, a produção nacional de algodão tem crescido acentuadamente, em função da reestruturação produtiva dos últimos anos. A auto-suficiência do mercado doméstico afeta favoravelmente o desenvolvimento do mercado futuro de algodão em pluma no Brasil, visto que o contrato da $B M \& F$ tem sido efetivo na redução do risco de preço para o produto brasileiro.

A análise de co-integração entre os mercados doméstico e internacional de algodão em pluma mostrou que os mesmos constituemse mercados integrados, indicando que seus preços evoluem conjuntamente no longo prazo. No curto prazo, a estimativa do Modelo de Correção de Erro parece indicar um certo descolamento contemporâneo dos preços nesses mercados. As variações do preço externo para o interno são transmitidas cinco e dez meses após uma dada perturbação. Entretanto, investigações mais profundas são necessárias para confirmar esses resultados.

Embora a conjuntura atual esteja dificultando o desenvolvimento do mercado futuro de algodão no Brasil, a reestruturação do sistema produtivo brasileiro e a internacionalização dos mercados futuros de commodities agropecuárias da BM\&F podem propiciar condições para $\mathrm{o}$ surgimento de novas demandas no sistema de comercialização nacional e internacional, fazendo com que o potencial desse mercado seja efetivado. 


\title{
PRICES RELATIONSHIP IN COTTON MARKET AND THE DEVELOPMENT OF THE COTTON FUTURES MARKET IN BRAZIL
}

\author{
Author: THEREZA CHRISTINA PIPPA ROCHELLE \\ Adviser: Prof. Dr. JOAQUIM BENTO DE SOUZA FERREIRA FILHO
}

\section{SUMMARY}

The present study was developed to analyze two factors affecting the potential for developing the cotton futures market in Brazil: a) the use of the New York Cotton Exchange (NYCE) futures contract for hedging the Brazilian cotton and b) the linkage between the Brazilian cotton financed imports and the interest rates arbitrage between domestic and international markets. Moreover, a co-integration analysis was conducted to identify the relationship between domestic and international cotton markets after the Brazilian economic liberalization process.

The optimal hedge ratios and hedging effectiveness were estimated in order to compare the Commodities \& Futures Exchange (BM\&F) and the NYCE futures contract as hedging instruments. Cotton cash and futures prices from january/1997 to december/1999 were used in the hedge ratios estimating. The optimal hedge ratio for the BM\&F cotton futures contract resulted in $40,42 \%$ and its hedging effectiveness was 
$22,5 \%$. The estimated hedge ratio for the NYCE cotton futures contract was not statistically significant.

These results show that the BM\&F cotton futures contract has been an efficient mechanism to manage the Brazilian cotton price risk although its low hedging effectiveness. The same can not be said about the NYCE cotton futures contract. In this context, there is a potential for developing the cotton futures market in Brazil.

Regression analysis were performed to verify the linkage between the Brazilian cotton financed imports and the interest rates arbitrage between domestic and international markets. The coefficients of the lagged independent variable (difference between domestic and international interest rates) showed not statistically significant in all estimated models.

Possibly, these results reflect the absence of a relationship between those variables or a relationship that could not be detected through the econometric methods used in this study. The second possibility is due to cotton financed imports and the interest rates behavior. It hangs on other economic variables and aspects related to the operational characteristics of the transactions, which evolve them.

Nevertheless these results, it seems reasonable to say that if the favorable interest rates and payment conditions offered in the international market remain the same there shall be cotton imports. The possibility of obtaining advantages or financial gains through financed imports can lead the importers to consider price risk and hedging for the imported cotton not important. This situation could be impairing the development of the cotton futures market in Brazil.

However, the domestic cotton production has increased due to the structural changes in the productive sector in the last few years. The self-sufficiency of the domestic market is propitious to the development 
of the cotton futures market in Brazil because the BM\&F futures contract has been effective in reducing price risk for the Brazilian product.

The co-integration analysis between the domestic and international cotton markets shows that they are integrated and their prices move together in the long run. In the short run, the Error Correction Model seems to indicate that prices in those markets are not contemporaneously linked. Changes in the international prices are transmitted only five and ten months after a given disturb. However, deeper investigations are necessary to confirm these results.

Although the actual national scenario is not favorable to the development of the cotton futures market in Brazil, the new productive structure for the Brazilian cotton and the BM\&F agricultural futures markets internationalization can provide conditions for new demand in the national and international trade system leading to the development of this market. 


\section{INTRODUÇÃO E JUSTIFICATIVA}

O curso da política agrícola brasileira tem sofrido grandes transformações nas últimas décadas. O crédito agrícola farto e subsidiado concedido durante a década de 70 deu lugar ao Programa de Garantia de Preço Minimo (PGPM), que predominou na década de 80 . Através de instrumentos como Aquisições do Governo Federal (AGF) e Empréstimos do Governo Federal (EGF), o governo intervinha diretamente nos mercados agricolas, participando ativamente da comercialização.

Com esse comportamento, o Estado teria dificultado durante muito tempo o desenvolvimento dos mercados futuros agropecuários no Brasil. A garantia de preços mínimos e as intervenções do governo na comercialização agrícola influenciam a livre formação e movimentação de preços. Essas ações alteram constantemente as características do mercado e dificultam a possibilidade de sucesso de um contrato futuro.

A crise fiscal do Estado evidenciou a exaustão desse tipo de política pelo seu elevado custo administrativo e eficácia duvidosa. Assim, a partir da década de 90, o escopo da PGPM tornou-se mais restrito e foram criados novos instrumentos de comercialização agrícola, como o Prêmio de Escoamento do Produto (PEP) e a Cédula de Produto Rural (CPR).

O controle da inflação, a partir de meados da década de noventa, tem proporcionado um ambiente favorável ao desenvolvimento dos 
mercados futuros agropecuários, cujas negociações no Brasil começaram em 1917, com a fundação da primeira Bolsa de commodities agrícolas, a Bolsa de Mercadorias de São Paulo (BMSP).

Durante as décadas de 1970 e 1980 foram lançados diversos contratos futuros de produtos agropecuários, mas somente em 1986, com o início das operações na Bolsa Mercantil \& de Futuros, é que ocorreu o grande salto da indústria de futuros no Brasil. Essa Bolsa inseriu-se entre as principais do mundo, impulsionada pela negociação de contratos futuros de dólar. Em 1991, fundiu-se à BMSP, dando origem à Bolsa de Mercadorias \& Futuros (BM\&F), onde são negociados atualmente os futuros de ativos financeiros e de commodities agrícolas. Em junho de 1997, ocorreu uma nova fusão entre a BM\&F e a Bolsa Brasileira de Futuros (BBF), sediada no Rio de Janeiro.

Hoje em dia, são transacionados na $B M \& F$ os contratos futuros de açúcar, álcool anidro, algodão, boi gordo, café, milho e soja. Embora lentamente, a $B M \& F$ vem avançando numa área em que outras Bolsas do Brasil e da América Latina fracassaram e, para isso, vem investindo pesadamente em recursos materiais e humanos (Spinola, 1997).

Ainda que a partir de valores iniciais modestos, o volume anual de contratos agrícolas negociados vem crescendo ano a ano: 45\% em 1995, 115\% em 1996, 6\% em 97, 34\% em 1998 e 44,2\% em 1999. Os contratos cujas negociações mais cresceram nos anos de 1997 e 1998 foram os de açúcar, café e algodão (Notícias BM\&F Brasil, 1999). No ano de 1999, a evolução positiva do volume de futuros agropecuários negociados deveu-se, fundamentalmente, aos contratos de açúcar, café e boi gordo. A recente regulamentação dos investimentos estrangeiros em contratos futuros de produtos agropecuários pelo Banco Central poderá ajudar a alavancar esse mercado. 
Nāo obstante, a liquidez dos futuros agropecuários ainda é muito pequena, face às possibilidades operacionais concretas desse mercado. Os enormes esforços empreendidos pela $B M \& F$ na implementaçāo de programas para estimular a utilizaçāo dos contratos futuros na agricultura nāo têm logrado o sucesso desejado, pois o potencial dos mercados futuros agropecuários ainda nāo foi efetivado.

$O$ fato é que as respostas para esse problema dependem de um amplo programa de pesquisa nessa área, ainda pouco desenvolvida no Brasil. Por essa razāo, é de fundamental importância estudar os fatores que afetam o potencial de desenvolvimento do mercado futuro de commodities agropecuárias no país.

No presente estudo, pretende-se proceder a análise de dois fatores que afetam o potencial de desenvolvimento do mercado futuro de algodāo no Brasil: a utilizaçāo do contrato futuro de algodāo em pluma da New York Cotton Exchange (NYCE) para hedging de preço do algodāo brasileiro e a possibilidade de as importações financiadas de algodāo em pluma estarem vinculadas à arbitragem das taxas de juros nos mercados doméstico e internacional.

A escolha desse produto é bastante oportuna, uma vez que a $B M \& F$ relançou, em 1996, o contrato futuro cambial de algodāo em pluma, num momento em que o setor cotonícola brasileiro passa por importantes transformações estruturais, decorrentes tanto da incipiente desregulamentaçāo dos mercados agrícolas quanto da liberalizaçāo comercial intensificada durante a década de noventa.

\subsection{0 problema e sua importância}

A partir da segunda metade da década de 1980, os mercados futuros e de opções cresceram internacionalmente de forma notável, 
verificando-se a criação de novas Bolsas em todo o mundo e esforços para a introdução de novos contratos por parte das já existentes. A história tem mostrado que muitos desses contratos sobrevivem, enquanto outros permanecem ativos apenas por um curto periodo de tempo.

A tendência à liberalização das economias tem levado muitos paises a tentar desenvolver seus mercados futuros. Bollman et al. (1998) afirmam que para o sucesso de um contrato futuro, um setor ou a economia em geral precisa experimentar algumas transformaçōes significativas ou alteraçōes estruturais tal como liberalização do mercado financeiro ou a mudança para uma economia de mercado.

Como parte de uma transformação econômica ou mudança estrutural, as firmas têm que ajustar seu sistema de estabelecimento de preços e estratégias de mercado, de forma a adotar mais prontamente as negociaçōes futuras como centrais em suas estratégias de gerenciamento de risco e preço. Sem essa mudança em uma indústria ou economia é questionável se um setor irá adotar os contratos futuros para gerenciar risco e preço em substituição às práticas específicas preexistentes no setor.

Algumas mudanças na economia brasileira, ocorridas nesta década, alteraram profundamente o cenário para a cotonicultura nacional: a) a abertura comercial, intensificada a partir de 1990, tem submetido o algodão nacional à forte competição com o produto importado e vem induzindo a transformaçōes no sistema produtivo, que começa a adotar um novo modelo de expansão, baseado em um padrão mais empresarial para a atividade; b) a intervenção mais ativa do governo na comercialização do algodão em pluma, impedindo que o preço da mercadoria varie livremente, de acordo com as condiçōes de oferta e demanda do mercado; c) a retomada dos fluxos internacionais 
de capital em direção ao Brasil, tem levado à expansão das importaçōes, em especial das financiadas e d) a valorização cambial, particularmente após a implantação do Plano Real, favoreceu as importaçōes ${ }^{1}$.

Nesse contexto, a análise do potencial de utilização do contrato futuro de algodão em pluma, relançado pela $B M \& F$, como instrumento de administração de risco para os diversos segmentos da cadeia produtiva assume especial relevância, porque essas transformaçōes econômicas e setoriais podem afetar as necessidades concretas de utilização desse contrato.

Considerando-se que o desenvolvimento bem sucedido de um mercado futuro está associado à sua liquidez, quanto maior a necessidade do contrato, maior o seu potencial de desenvolvimento. Assim, os fatores que afetam a utilização do contrato futuro de algodão em pluma da BM\&F constituem-se o aspecto chave da análise do potencial de desenvolvimento do mercado futuro de algodão no Brasil.

Deste modo , a possibilidade de utilizar o contrato futuro de uma Bolsa com maior liquidez como a $\mathrm{NYCE}$, para realizar o hedging de preço do algodão brasileiro pode afetar o potencial de desenvolvimento do mercado futuro dessa commodity no Brasil.

Espera-se que possa existir uma maior correlação entre os preços à vista e futuro do algodão no Brasil relativamente à correlação entre o preço à vista do algodão no Brasil e o preço futuro na NYCE no curto prazo. Isso implicaria na maior efetividade do contrato futuro da $B M \& F$ como instrumento de administração de risco de preço para o algodão brasileiro relativamente ao contrato da NYCE.

Além disso, a possibilidade de as importaçōes financiadas de algodão em pluma estarem vinculadas à arbitragem entre as taxas de

\footnotetext{
1 Em meados de Janeiro de 1999, o Brasil abandonou a âncora cambial e adotou o regime de taxas de câmbio flutuantes, implicando numa forte desvalorização de sua moeda.
} 
juros interna e externa poderia estar afetando o potencial de desenvolvimento do mercado futuro de algodão no Brasil porque reduz a demanda por hedging no mercado interno.

$\mathrm{O}$ retorno financeiro obtido pelos importadores devido ao diferencial entre as taxas de juros interna e externa e prazos dilatados de pagamento no mercado internacional podem estar restringindo a necessidade de hedging da matéria-prima, pois, nessas condições, o hedge de preço do algodão importado não estaria preocupando esses agentes. E, ainda que estivessem interessados nessa operação, a origem do produto (nacional ou importado) pode implicar em necessidades diferentes quanto à administração do risco de preço.

\subsection{Objetivos}

O objetivo do presente estudo é analisar como alguns fatores, decorrentes de novas condições econômicas e setoriais, afetam o potencial de desenvolvimento do mercado futuro de algodão no Brasil. Constituem-se objetivos especificos deste estudo:

a) verificar se o contrato futuro de algodão em pluma da NYCE é um mecanismo mais efetivo de administração do risco de preço do algodão no Brasil, comparativamente ao contrato futuro da BM\&F;

b) analisar a evolução das importaçōes financiadas de algodão em pluma, a fim de verificar se as mesmas estão vinculadas à arbitragem das taxas de juros interna e externa.

Adicionalmente, pretende-se analisar a integração dos mercados doméstico e internacional de algodão em pluma, a fim de verificar se esses preços têm evoluído conjuntamente no longo prazo. A relação entre os preços no longo prazo é uma condição necessária, mas não suficiente para os propósitos de hedging (Arbex \& Carvalho, 1999). 
Assim, a análise da relação dos preços do algodão em pluma nos mercados doméstico e internacional torna-se relevante na medida em que a estrutura de formação de preço no mercado interno pode afetar a administração do risco pelos agentes.

\subsection{Hipóteses}

O desenvolvimento do presente estudo está baseado nas seguintes hipóteses:

- o contrato futuro da BM\&F seria um instrumento mais efetivo para administração do risco de preço do algodão brasileiro em relação ao contrato da NYCE;

- as importações financiadas de algodão em pluma podem estar vinculadas à arbitragem das taxas de juros interna e externa;

- os preços do algodão em pluma nos mercados doméstico e internacional evoluiriam conjuntamente no longo prazo, indicando uma relação entre essas variáveis. 


\section{PANORAMA DO MERCADO MUNDIAL DE ALGODẢO EM PLUMA}

A produção mundial de algodão em pluma na safra 99/00 foi de 19 milhões de toneladas, sendo os principais produtores China, Estados Unidos, Índia, Paquistão e Uzbequistão. Entre 1991/92 e 1999/00, o total produzido no mundo esteve entre 16 e 20 milhões de toneladas de algodão em pluma por ano. Os Estados Unidos e a China alternaram, durante a década de 1990, a posição de maior produtor mundial dessa fibra.

Com relação ao consumo, os quatro principais paises produtores também ocupam as posições de maiores consumidores mundiais. $\mathrm{Na}$ China, o consumo excede a produção e o país aparece, em alguns anos da década de noventa, como grande importador de algodão em pluma no mercado internacional. Já os Estados Unidos consomem mais da metade de sua produção e exportam o excedente, figurando, juntamente com a República do Uzbequistão, como maior exportador mundial dessa fibra. Os países francófonos da África ${ }^{2}$ também são importantes exportadores de algodão no cenário mundial, destacando-se Benin e Togo, pela qualidade superior da fibra produzida.

As importações de algodão em pluma no mercado internacional mantiveram-se em torno de 6 milhões de toneladas no periodo 1991/92 a 1999/00. Dentre os principais importadores durante a década de

2 Benin, Burkina, Camarões, República Centro Africana, Chade, Costa do Marfim, Mali, Niger, Senegal e Togo. 
noventa estão a União Européia, os países do Sudeste Asiático ${ }^{3}$, China e Brasil. Os estoques mundiais de algodão em pluma situaram-se entre 7,5 e 10 milhões de toneladas durante a década de 90, exceto nas safras 1993/94 e 1994/95, quando os valores foram reduzidos para 6 e 6,5 milhões de toneladas, respectivamente.

As principais referências de preço no mercado internacional de algodão em pluma são o mercado de Liverpool, representado pelas cotações dos Índices Cotlook $A$ e $B$ e o mercado norte-americano, representado pelos preços futuros da New York Cotton Exchange (NYCE).

O Cotlook A Index e o Cotlook B Index são publicados diariamente pela Outlook Limited, um serviço de informação sobre o nivel de competitividade dos preços do algodão ofertado no mercado internacional, sediado no Reino Unido.

O Cotlook $A$ Index é uma média dos 5 menores preços do algodão em pluma ofertado pelas tradings internacionais, considerando-se as 14 principais origens ofertantes do produto de maior qualidade. O Cotlook $B$ Index é a média dos 3 menores preços ofertados pelas tradings internacionais, considerando-se as 8 principais origens ofertantes do produto de menor qualidade. Esses indices são baseados nos tipos de algodão equivalentes aos conceitos de qualidade de Liverpool, entregues ao preço CIF em portos do Norte da Europa, incluindo-se o lucro e a comissão do agente.

As cotações básicas dos Índices Cotlook $A$ e $B$, excluindo-se os custos do frete posto nos portos do Norte da Europa e acrescentando-se o custo do frete até os Estados Unidos, constituem o preço básico para efeito dos programas de subsidio naquele país. Já as cotações de mercado realizadas pelo United States Department of Agriculture

\footnotetext{
${ }^{3}$ Indonésia, Malásia, Filipinas, Cingapura, Tailândia e Vietnā.
} 
(USDA) indicam a média dos preços pagos aos produtores norteamericanos. Essas duas cotações estão refletidas nos preços futuros da NYCE, que também constituem-se referências do preço do algodão em pluma no mercado internacional.

A Figura 1 mostra a evolução mensal do preço do algodão em pluma no mercado brasileiro, dos Índices Cotlook $A$ e $B$ no mercado internacional e do preço futuro do algodão em pluma na $\mathrm{NYCE}$, durante o periodo de janeiro de 1985 a dezembro de 1999. Os preços no mercado brasileiro referem-se à cotação da pluma no atacado em São Paulo, levantados pela Companhia Nacional de Abastecimento (CONAB). Os preços da $\mathrm{CONAB}$, os Índices Cotlook $A$ e $B$ e o preço futuro do algodão em pluma na NYCE estão em centavos de dólar por libra peso. 


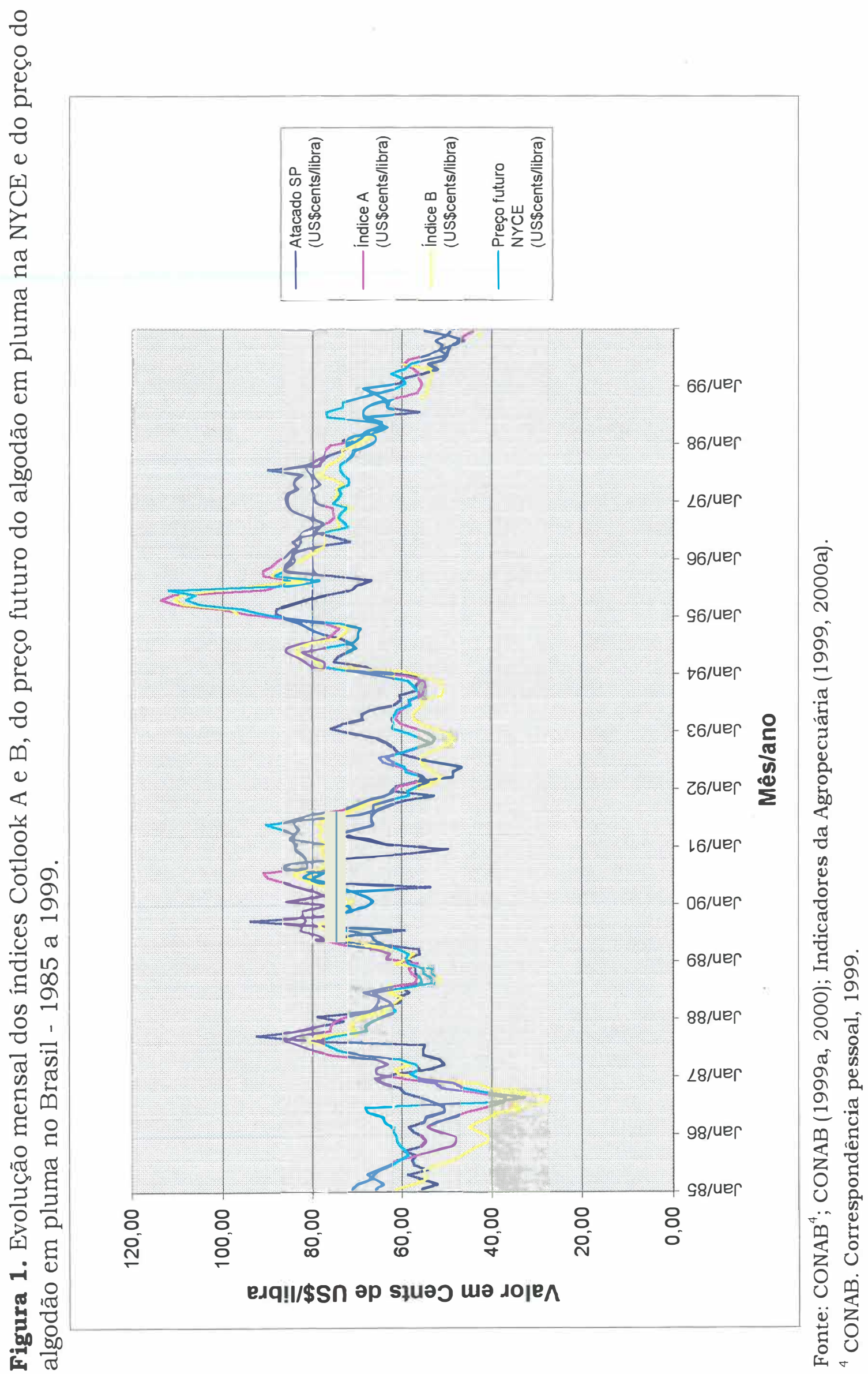




\section{O MERCADO BRASILEIRO DE ALGODÃO EM PLUMA}

\subsection{Produção de algodão em pluma no Brasil}

O papel desempenhado pelo algodão brasileiro no mercado mundial tem sofrido grandes transformações nos últimos 30 anos. A seqüência de políticas comerciais adotadas nesse periodo visou o abastecimento interno e o Brasil acabou passando da condição de exportador para importador dessa fibra. A crise instalada no setor algodoeiro desde a década de 70 foi agravada pela abrupta queda da tarifa de importação de algodão em pluma, que passou de $55 \%$ para zero com o processo de abertura comercial iniciado em 1988 e intensificado a partir de 1990.

A área plantada com algodão no Brasil tem sofrido drástica redução desde 1990, ano em que foram cultivados $1.963,8$ mil hectares. Na safra 1999/00, a área plantada reduziu-se para 805,6 mil hectares, ou seja, menos da metade da extensão cultivada no início da década (Figura 2). 
Figura 2. Área plantada, produção e produtividade da cultura de algodão no Brasil - 1990 a 2000.

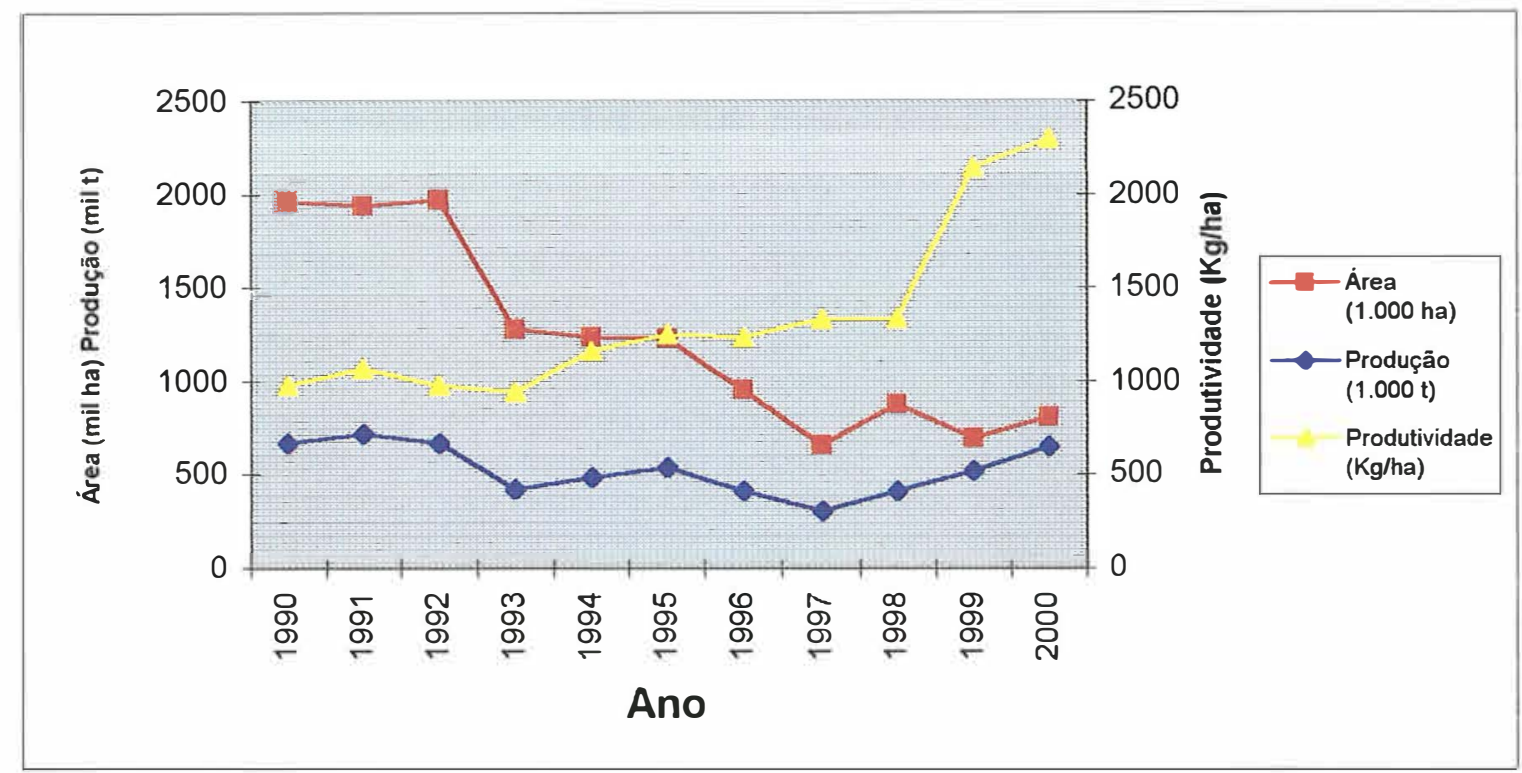

Fonte: BM\&F (1997, 2000a); Indicadores da Agropecuária (2000b).

Apesar de a produtividade ao longo da década ${ }^{5}$ ter aumentado, a produção brasileira de algodão em pluma, que foi de 665,7 mil toneladas em 1990, reduziu-se para 520,1 mil toneladas em 1998/99, indicando uma queda de aproximadamente $22 \%$ na quantidade produzida durante o período. Em 1999/00, a safra brasileira aumentou para 647,5 mil toneladas de algodão-em pluma (Figura 2). A redução da produção nacional entre 1990 e 1998/99 e a aparente recuperação a partir de então ocorreu de forma diferenciada entre os estados brasileiros.

A crise na cotonicultura nordestina, que já vinha ocorrendo desde meados da década de 80 , foi agravada pela abertura comercial e a produção de algodão nos estados do Nordeste reduziu-se sobremaneira nos anos noventa. Os estados do Norte e Nordeste produziram 113,9 mil

5 Durante a década de noventa, houve aumento na produção por área plantada no Brasil, que passou de 978 t/ha de algodão em caroço em 1990 para 2.296 t/ha em 1999/00. Entretanto, esse acréscimo de produtividade foi díspar entre os estados brasileiros. 
toneladas em 1991, mas na safra 1998/99, a produção atingiu apenas 37,3 mil toneladas, indicando uma queda de $67,3 \%$ na quantidade produzida, relativamente ao início da década.

Entretanto, deve-se ressaltar a recente expansão da cotonicultura para a região oeste da Bahia, a qual tem se mostrado bastante competitiva. O perfil da produção naquela região é compatível com aquele encontrado nos Estados Unidos e Argentina (Gonçalves, 1997). Segundo dados da CONAB, a produção de algodão na Bahia aumentou de 14,8 mil toneladas em 1998/99 para 41,2 mil toneladas em 1999/00.

A produção de algodão em pluma nos estados de São Paulo e Paraná, regiōes tradicionais de cultivo, também foi decrescente entre 1991 e 1999/00. No estado de São Paulo, a produção passou de 123,6 mil toneladas em 1991 para 48,6 mil toneladas na safra 1999/00, indicando uma redução de $60,7 \%$ na quantidade produzida. No Paraná, a produção caiu de 344,2 mil toneladas para 39,8 mil toneladas no mesmo período, ou seja, em 1999/00 a quantidade produzida passou a ser 88,4\% menor do que em 1991. Essa drástica redução da produção reflete a crise enfrentada pela cotonicultura nos estados de São Paulo e Paraná, que respondiam por aproximadamente $65 \%$ da produção nacional de algodão em pluma em 1991 e, na safra 1999/00, participaram com apenas $13,7 \%$.

Contrastando com as demais regiōes, nos estados de Mato Grosso, Mato Grosso do Sul e Goiás, a produção aumentou paulatinamente no período 1990 a 1997/98 e, na safra 1998/99, houve um salto na produção dos três estados. Esse acréscimo acelerado na produção pode ser explicado, pelo menos em parte, pelos excelentes 
resultados financeiros obtidos pelos produtores nas safras 1996/97 e $1997 / 98^{6}$.

Em Mato Grosso, a produção passou de 20,4 mil toneladas de algodão em pluma no ano de 1990 para 34,8 mil toneladas em 1997/98, saltando então para 226,4 mil toneladas em 1998/99 e para 311 mil toneladas em 1999/00. A quantidade de algodão em pluma produzida naquele estado aumentou quase nove vezes entre as safras 1997/98 e 1999/00 e mais de quinze vezes entre o início e o final da década. Atualmente, o Mato Grosso é responsável por quase metade da produção nacional dessa fibra.

Em Mato Grosso do Sul, a produção de 24,5 mil toneladas de algodão em pluma em 1990 aumentou para 41,7 mil toneladas em 1999/00. Já o estado de Goiás, que produziu 29,1 mil toneladas de algodão em pluma em 1990, atingiu o total de 69,4 mil toneladas em 1997/98 e 77,2 mil toneladas em 1999/00. Entre 1990 e 1999/00, a produção em Goiás aumentou aproximadamente 2,7 vezes.

$\mathrm{O}$ aumento da produção naqueles estados mostra que eles vêm se configurando como a nova fronteira cotonícola do Brasil. O sistema de produção adotado pelas propriedades instaladas nas regiões do Brasil Central difere bastante do modelo de expansão da cotonicultura nas regiões tradicionais de cultivo - estados de São Paulo e Paraná. Nos estados do Centro-Oeste, as áreas cultivadas com algodão são grandes propriedades, as quais utilizam tecnologia intensiva em capital. São extensões de terra com intensa mecanização, especialmente na colheita, muitas vezes integradas a algodoeiras próprias, quando não a fiações, que atuam diretamente no mercado de pluma ou fio (Gonçalves, 1997).

\footnotetext{
${ }^{6}$ Garantido, pelo menos no MT (principal estado produtor), pelo Programa de Incentivo à Cultura do Algodão (PROALMAT).
} 
Essa reestruturação produtiva, baseada em um padrão mais empresarial para a atividade aliada à incipiente recuperação da produção nacional apontam para a função cada vez mais importante dos mecanismos de mercado em substituição às políticas públicas tradicionais. As novas demandas em termos de inovações no sistema de comercialização poderão criar condições ao desenvolvimento bem sucedido do mercado futuro de algodão no Brasil.

\subsection{Aspectos relevantes da comercialização de algodão no Brasil}

A atual reestruturação do setor, tendo o Centro-Oeste como a nova fronteira de produção cotonícola, traz consigo inovações no sistema de comercialização do algodão. A Figura 3 mostra um fluxograma da produção têxtil no Brasil, com base no qual são feitas algumas considerações genéricas à respeito da estrutura de mercado em cada segmento e das transações entre eles.

No caso brasileiro, a produção de têxteis de algodão envolve sete etapas fundamentais: cotonicultura, algodoeira, fiação, tecelagem, tinturaria e acabamento, indústria de vestuário e distribuição varejista (Figura 3). O processo tem início nas propriedades rurais, as quais produzem o algodão em caroço, transformado em pluma nas algodoeiras, em fio de algodão de diversas especificações na fiação, em tecido cru na tecelagem, que é estampado na tinturaria e acabamento e transforma-se em roupas e outros produtos na indústria de confecções (Urban et al., 1995).

Nas regiões tradicionais de cultivo, os produtores vendem o algodão em caroço às algodoeiras, que beneficiam e classificam o produto e comercializam os fardos de algodão em pluma com as indústrias de fiação. 
Figura 3. Fluxo Genérico da Produçāo de Têxteis no Brasil.

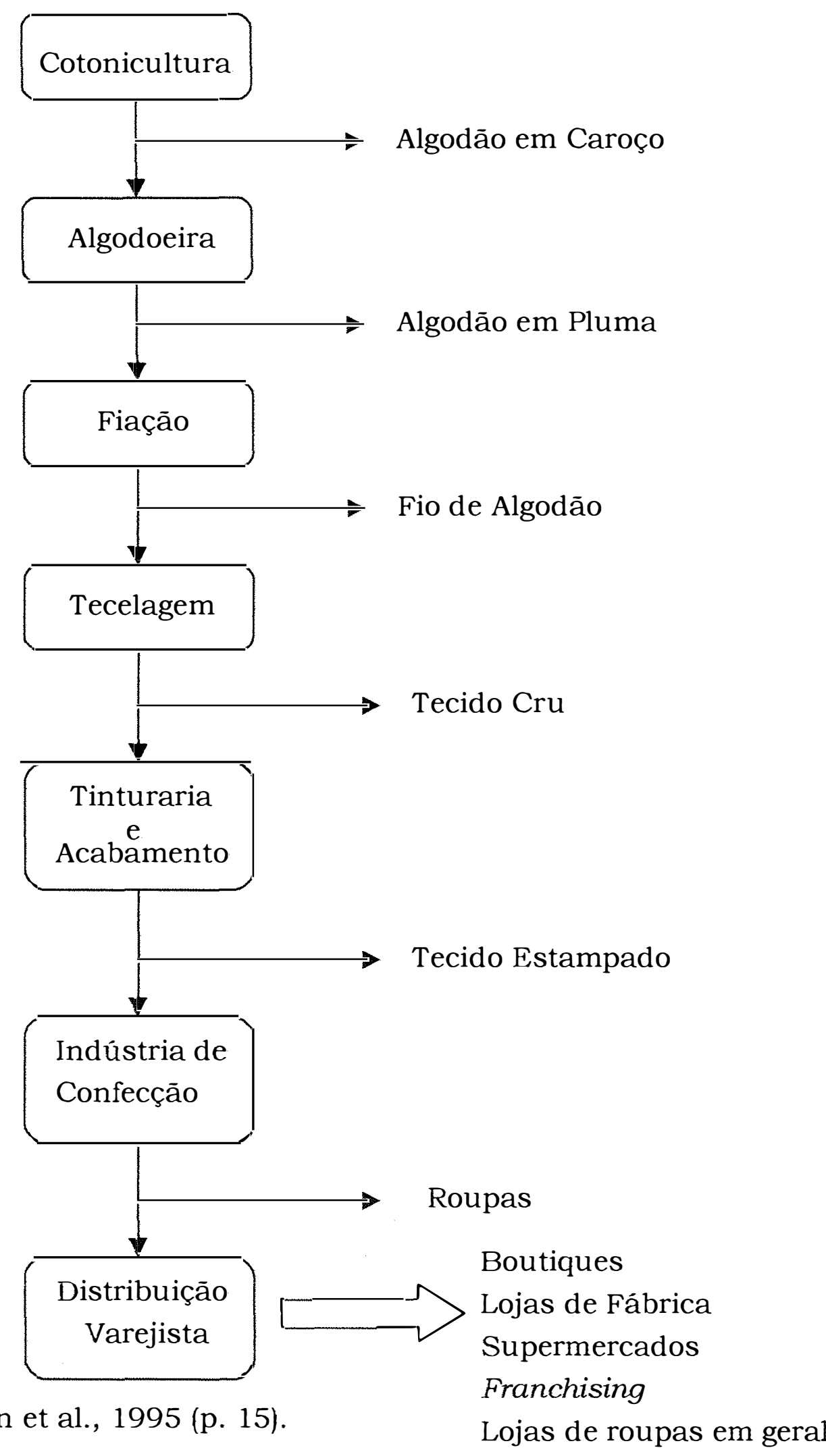


O mercado de algodão em caroço exibe sazonalidade, dado o pico de oferta e preços reduzidos na safra e menores volumes negociados a preços elevados na entressafra. Tal situação decorre da falta de flexibilidade para venda da produção na colheita, já que muitos produtores, principalmente pequenos e médios, têm dividas a saldar e/ou não têm recursos para pagar o beneficiamento e/ou armazenamento do produto.

O "maquinista", que é o comprador de algodão em caroço ligado à algodoeira, atua com maior poder de barganha que o cotonicultor no sistema tradicional de comercialização, uma vez que o algodão em pluma é armazenável por longos periodos, mas o algodão em caroço pode estragar com rapidez. Normalmente, o preço recebido pelo produtor é referenciado ao tipo 6, com ágios e deságios por qualidade.

Contudo, esse padrão de comercialização vem se alterando recentemente com o cultivo de extensas áreas por um número reduzido de produtores no Centro-Oeste. Da mesma forma que nas principais nações produtoras do mundo, os cotonicultores passaram a pagar pelos serviços de beneficiamento, comercializando o caroço, o línter e atuando diretamente no mercado de algodão em pluma7.

A crise nas regiões tradicionais de cultivo levou à erradicação de muitas algodoeiras. As exceções constituem-se poucas empresas de maior porte, as quais têm se ajustado à reestruturação do setor produtivo, deslocando-se para as regiões do Brasil Central, a fim de beneficiar o algodão produzido pela cotonicultura empresarial.

\footnotetext{
7 No que tange à transação do algodão em pluma entre a algodoeira e a fiação, existem ágios e deságios, de acordo com o padrão do fardo resultante do tipo de algodão em caroço utilizado e da capacidade da algodoeira "limpar" o produto no beneficiamento (Urban et al., 1995).
} 
Assim, as alterações no sistema de comercialização do algodão têm sido no sentido de os produtores comercializarem a pluma e os beneficiadores deixarem o papel de intermediários e passarem a prestadores de serviços. Portanto, observa-se uma tendência de os produtores venderem o algodão em pluma diretamente às fiações.

Outra importante inovação nos segmentos produtivo e de comercialização do algodão nos estados do Centro-Oeste tem sido a verticalização da estrutura produtiva, com o surgimento de propriedades associadas a algodoeiras próprias. Além disso, algumas evidências encontradas em pesquisa realizada por Ferreira Filho et al. (1998), sugerem a existência de um mercado à termo bem estabelecido nas novas regiōes cotonícolas, onde os produtores buscam garantir antecipadamente a venda de uma parte de sua safra para cobrir as despesas de custeio. Esse novo modelo poderá criar novas demandas em termos de estratégias de redução do risco de preços através de instrumentos de mercado.

No segmento da indústria têxtil, a principal tendência observada é a redução do número de empresas e conseqüente concentração do setor. Durante a década de noventa, a abertura comercial expôs todo o conjunto da produção têxtil brasileira à competição com os produtos importados, não obstante a cotonicultura ter sofrido os impactos mais fortes desse processo. Para ajustar-se à nova realidade do mercado, houve um pujante processo de renovação do parque de máquinas e equipamentos no setor industrial.

Entretanto, tal comportamento não ocorreu de forma generalizada e resultou numa profunda heterogeneidade das empresas quanto ao porte, tecnologia e gerência administrativa das indústrias têxteis. Atualmente, o setor é formado, de um lado, por poucas firmas líderes de maior porte as quais mostram-se competitivas no mercado internacional 
e, de outro, por muitas empresas de menor porte, as quais alimentam o processo de concentração, ainda em curso dentro do segmento industrial (Jayo \& Nunes, 1998).

A estrutura de mercado da produção têxtil concentra-se conforme caminha para o produto final. As fiações apresentam, geralmente, algum tipo de integração a jusante, em função do tipo de tecnologia empregada (em regime contínuo e de forma interligada) e elevada escala minima de produção (Gorini \& Siqueira, 1997). Dessa forma, as empresas de fiação, tecelagem e confecção são capazes de atuar com maior poder de mercado em duas transações dentro do processo: com os cotonicultores e com os consumidores (Urban et al., 1995).

É importante salientar que essa conformação afeta o potencial de desenvolvimento do mercado futuro de algodão no Brasil porque o poder de mercado do segmento industrial altera a estrutura de formação dos preços do algodão em pluma, dificultando o funcionamento dos mercados futuros.

\subsection{As importações brasileiras de algodão em pluma}

Desde o início do processo de abertura comercial no Brasil, as importações de algodão em pluma aumentaram acentuadamente, objetivando garantir o abastecimento interno dessa fibra. Considerandose cada país isoladamente, o Brasil inclui-se entre as maiores nações importadoras de algodāo em pluma do mundo, adquirindo cerca de um terço de suas necessidades atuais de consumo.

Em 1990, quando foram abolidas as tarifas para a importaçāo de algodão em pluma no país, as aquisições brasileiras no mercado internacional corresponderam a $2 \%$ do total das importações mundiais. Entretanto, a cada ano da década de noventa, esse percentual oscilou 
entre $4 \%$ e 6,5\%, exceto em 1992/93 e 1996/97, quando o Brasil importou, respectivamente, cerca de $8,5 \%$ e $7,5 \%$ do total mundial.

Nesse contexto, a administração do risco de preço no mercado de algodão em pluma no Brasil adquiriu uma importância que não tinha até então, quando o país era relativamente fechado ao comércio exterior. A redução das barreiras tarifárias deu origem a pressões sobre a produção e a estrutura da cotonicultura nacional.

Em 1992, o valor das importações brasileiras de algodão em pluma foi US\$218,48 milhões, enquanto em 1999 esse valor correspondeu a US\$393 milhões. O aumento foi de aproximadamente $80 \%$ nos gastos com a aquisição do produto importado (Figura 4). As importações brasileiras dessa fibra responderam por cerca de $33 \%$ do déficit no saldo da balança comercial do país em 1999, o qual foi US\$ 1.206 milhões.

A isenção tarifária das importações de algodão em pluma, a partir de 1990, antecedeu um período de queda nas cotações internacionais, a qual persistiu até 1992. Naquele ano, os baixos preços no mercado externo e a redução da produção nacional favoreceram as importações, as quais triplicaram e atingiram volumes recordes em 1993. Em 1994 e 1995, as aquisições brasileiras no mercado internacional mantiveram-se em patamares elevados (Figura 4), apesar do aumento nas cotações externas, após novembro de 1993.

A queda na produção nacional aliada à redução dos preços no mercado externo levou à internalização de 470 milhões de toneladas de algodão em pluma nos anos de 1996 e 1997. A partir de 1998, a produção brasileira começou a se recuperar e, apesar dos preços internacionais decrescentes, houve contração do volume importado naquele ano e no seguinte (Figura 4). 
Figura 4. Valor CIF e peso líquido das importações brasileiras de algodão em pluma - 1992 a 1999.

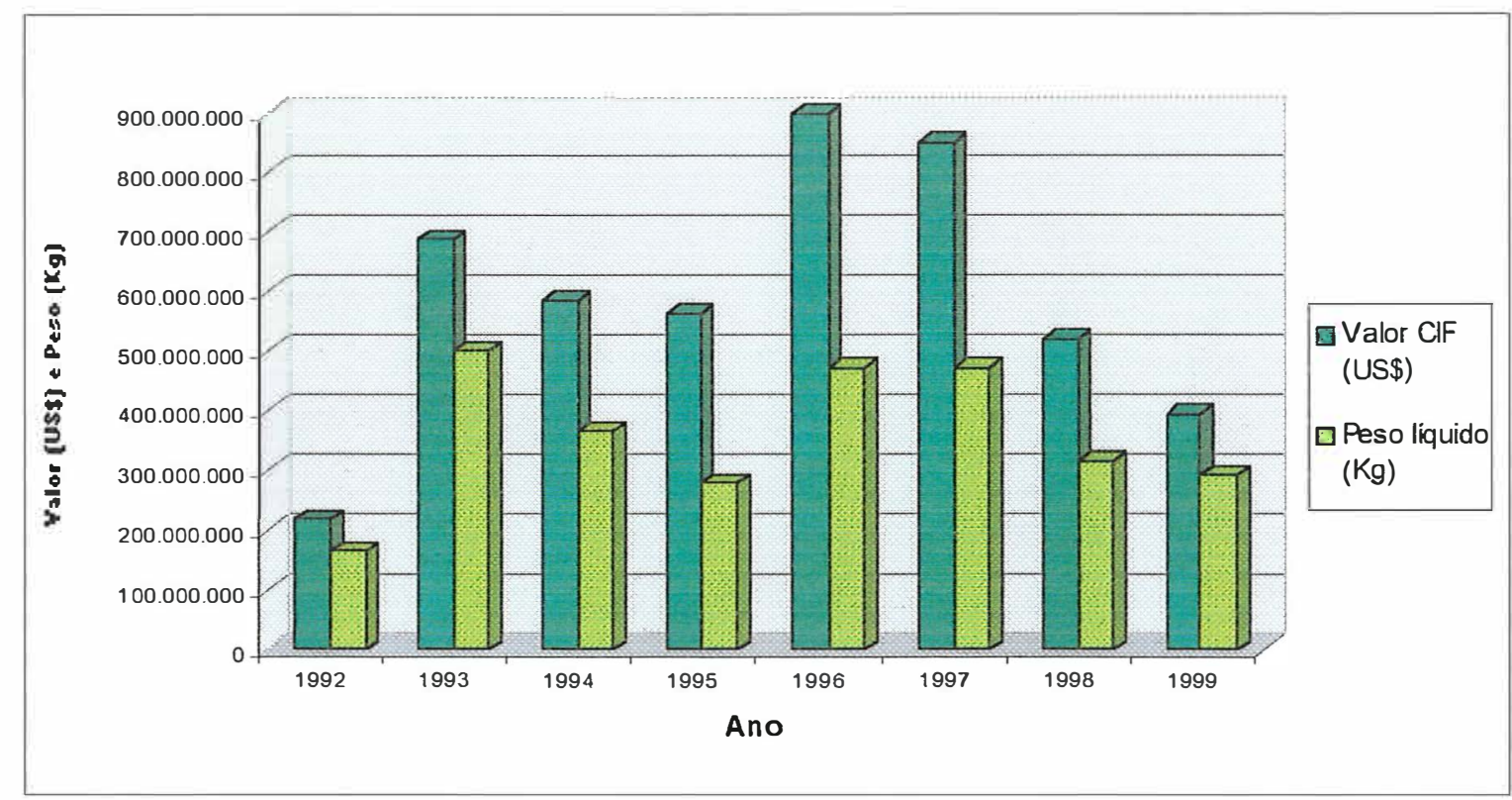

Fonte: Secretaria da Receita Federal (SRF), Coordenação de Estatísticas EconômicoTributárias - Divisão de Estatísticas do Comércio Exterior ${ }^{8}$ (COEST/DIVEX).

Em 1999, parte da redução na quantidade de algodão importada deve estar relacionada à desvalorização cambial, ocorrida em meados de janeiro daquele ano, a qual tornou mais caro o produto importado. Além disso, havia a incerteza dos importadores quanto aos desdobramentos do regime de taxas de câmbio flutuantes, adotado desde então.

Diversos fatores contribuiram para o aumento das importações brasileiras de algodão em pluma durante a década de noventa. De acordo com Rezende et al. (1997), incluem-se a) a abertura comercial, intensificada a partir de 1990; b) a valorização cambial, particularmente após a implantação do Plano Real até meados de janeiro de 1999; c) a baixa participação do custo de transporte relativamente ao preço do algodão e d) a retomada dos fluxos internacionais de capital em direção

\footnotetext{
${ }^{8}$ SRF, COEST/DIVEX. Correspondência pessoal, 1999 e 2000.
} 
ao Brasil, que levou à expansão das importaçōes, em especial das financiadas.

O processo de abertura comercial no Brasil começou no final da década de oitenta, quando houve uma abrupta redução na tarifa de importação de algodão em pluma. A alíquota vigente em 1986 era 55\%, passou para 10\% em 1988 e, a partir de 1990, as barreiras tarifárias à importação do algodão em pluma foram zeradas. Assim, o mercado brasileiro esteve aberto tanto ao produto originário dos países do MERCOSUL, constituído em 1991, como de terceiros países.

Entretanto, a partir de 1995, com o estabelecimento da Tarifa Externa Comum (TEC) pelos países do MERCOSUL, o algodão em pluma foi incluído na lista de exceçōes à TEC. Desde então, a alíquota de importação para a pluma de algodão evoluiu de 1\% em 1995, para 3\% e $6 \%$ durante o ano de 1997, permanecendo nesse último patamar em 1998. Nos anos de 1999 e 2000, as importaçōes de algodão em pluma deverão ser tarifadas em $8 \%$ e, a partir de 2001 , em $6 \%$.

Internamente, a política macroeconômica conduzida pelo governo após a implantação do Plano Real levou à uma persistente apreciação cambial, revertida somente pela adoção do regime de taxas de câmbio flutuantes, após a crise ocorrida em janeiro de 1999. Sem dúvida, as taxas de câmbio prevalecentes entre julho de 1994 e dezembro de 1998 favoreceram as importaçōes de algodão em pluma pelo Brasil.

Além disso, o fato de o custo de transporte representar um percentual pequeno do preço do algodão, faz com que as mudanças nas políticas cambial e/ou comercial dos países exerçam impactos mais fortes sobre o setor cotonícola comparativamente a outros, cujo custo de transporte internacional funciona como uma "barreira natural" de proteção ao produto doméstico (Rezende et al., 1997). 
Quanto à retomada dos fluxos comerciais em direção ao Brasil, a mesma ocorreu a partir de meados da década de noventa. Desde a adoção do Plano Real, a variação cambial tornou-se mais previsivel, reduzindo o risco associado à captação de recursos externos. Essa situação modificou-se a partir de medos de janeiro de 1999, quando foi adotado o regime de taxas de câmbio flutuantes no país.

A captação de recursos externos, a qual correspondeu a US\$11,6 bilhões em 1991, saltou para US\$ 54,2 bilhões em 1995 e para US\$ 106,09 bilhões em 1999. Entretanto, esses dados registrados pelo Banco Central do Brasil no balanço de pagamentos, não incluem os financiamentos com prazos inferiores a 360 dias, os quais fazem parte da conta de capitais de curto prazo.

O financiamento das importações insere-se tanto na captação de recursos externos, quando o prazo de financiamento é superior a 360 dias, como na conta de capitais de curto prazo, quando o prazo de financiamento é inferior a esse periodo. Essas operações de financiamento são importantes porque possibilitam o acesso dos importadores a taxas de juros substancialmente inferiores àquelas vigentes no mercado interno. Além disso, somadas aos prazos de pagamento bastante dilatados oferecidos no mercado internacional, essas taxas de juros permitem obter ganhos financeiros através de operações de arbitragem entre os mercados interno e externo.

As importações brasileiras de algodão em pluma, segundo o país de origem, podem ser observadas na Tabela 1. Nota-se pela referida Tabela que o Paraguai foi o principal exportador de algodão em pluma para o Brasil entre 1992 e 1995. 
Tabela 1. Importaçōes brasileiras de algodão em pluma, segundo o país de origem - 1992 a 1999.

\begin{tabular}{|c|c|c|c|}
\hline Ano & Pais de Origem & Văor CIF (US\$) & 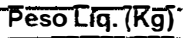 \\
\hline 1992 & Paraguai & 713.518 .982 & 85.251 .565 \\
\hline 1992 & URSS & 66.279 .478 & 52.583 .959 \\
\hline 1992 & Argentina & 21.537 .597 & 17.599 .502 \\
\hline 1992 & Grécia & 4.244.277 & 303.057 \\
\hline 1992 & Paquistāo & 3.229 .193 & 2.530 .553 \\
\hline 1992 & Outros & 9.672 .094 & 6.843 .837 \\
\hline "1952 & Total & 218.481 .621 & 785.172 .473 \\
\hline 7993 & Paraguai & -755.768 .989 & 110.081 .692 \\
\hline 1993 & EUA & 78.955 .267 & 56.941 .177 \\
\hline 1993 & Grécia & 74.022 .463 & 47.824 .187 \\
\hline 1993 & Federação da Rússia & 63.603 .419 & 49.077 .670 \\
\hline 1993 & Mali & 62.820 .451 & 46.914 .168 \\
\hline 1993 & Outros & 251.609 .667 & 198.344 .676 \\
\hline 1993 & Total & 585.780 .256 & 509.183 .570 \\
\hline-7994 & Paraguai & 128.781 .952 & 76.384 .742 \\
\hline 1994 & Federação da Rússia & 123.984 .546 & 76.912 .479 \\
\hline 1994 & Argentina & 103.485 .484 & 62.499 .590 \\
\hline 1994 & EUA & 92.447 .220 & 64.447 .652 \\
\hline 1994 & Rep. Do Uzbequistão & 39.517 .777 & 23.272 .322 \\
\hline 1994 & Outros & 96.463 .016 & 62.012 .943 \\
\hline 7994 & Total & 584.679 .995 & 365.520 .128 \\
\hline 7995 & Paraguai & 155.896 .606 & 74.612 .345 \\
\hline 1995 & Rep. Do Uzbequistão & 115.639 .048 & 56.834 .323 \\
\hline 1995 & EUA & 83.302 .671 & 42.652 .301 \\
\hline 1995 & Argentina & 72.445 .270 & 36.172 .698 \\
\hline 1995 & Benin & 44.865 .744 & 23.083 .207 \\
\hline 1995 & Outros & 90.940 .230 & 45.671 .470 \\
\hline -1995 & Tơtal- & 563.086 .56 & 279.026 .344 \\
\hline 7996 & Argentina & 233.633 .151 & 128.352 .328 \\
\hline 1996 & Rep. Do Uzbequistão & 464.599 .582 & 88.608 .614 \\
\hline 1996 & Paraguai & 162.449 .395 & 85.259 .549 \\
\hline 1996 & EUA & 92.373 .606 & 44.688 .007 \\
\hline 1996 & Benin & 37.275 .671 & 18.779 .915 \\
\hline 1996 & Outros & 206.195 .052 & 105.453 .694 \\
\hline 7996 & Total' & 896.526 .457 & 477.742.107- \\
\hline 7997 & Argentina & 269.860 .923 & $752.661 .711^{-}$ \\
\hline 1997 & Rep. Do Uzbequistão & 105.130 .616 & 60.835 .093 \\
\hline 1997 & EUA & 103.571 .088 & 55.796 .640 \\
\hline 1997 & Benin & 91.520 .380 & 48.230 .120 \\
\hline 1997 & Paraguai & 82.884 .118 & 44.033 .480 \\
\hline 1997 & Outros & 195.949 .580 & 109.200 .019 \\
\hline 1997 & Total & 848.916 .705 & 470.757 .063 \\
\hline 1998 & Argentına & 737.946 .605 & 89.475 .526 \\
\hline 1998 & Benin & 87.425 .862 & 48.416.109 \\
\hline 1998 & Paraguai & 74.326 .210 & 47.526 .634 \\
\hline 1998 & Rep. Do Uzbequistão & 58.653 .692 & 38.219 .638 \\
\hline 1998 & EUA & 58.138 .550 & 33.099 .532 \\
\hline 1998 & Outros & 103.241 .007 & 59.660 .569 \\
\hline-7998 & Total & 519.731 .926 & 316.368 .008 \\
\hline 1999 & Argentina & -122.873 .597 & 704.765 .470 \\
\hline 1999 & Paraguai & 07.295 .947 & 49.091 .021 \\
\hline 1999 & Benin & 59.451 .360 & 39.995 .698 \\
\hline 1999 & Rep. Do Uzbequistão & 31.947 .580 & 23.265 .914 \\
\hline 1999 & Togo & 24.664 .744 & 16.851 .365 \\
\hline 1999 & Outros & 83.947 .196 & 56.874 .672 \\
\hline 7999 & Total & 360.180 .424 & 290.244 .140 \\
\hline
\end{tabular}

Fonte: SRF, COEST/DIVEX (citado na página 22). 
A partir de 1996, a Argentina assumiu a primeira posição no suprimento dessa fibra para o mercado brasileiro. Durante a década de 1990, a Federação da Rússia, a República do Uzbequistão, os Estados Unidos e Benin estiveram entre as cinco principais origens das importações brasileiras de algodão em pluma. Destaca-se também a importância dos países do MERCOSUL no abastecimento interno.

No mercado internacional de algodão em pluma predominam grandes trading companies, que operam com elevada capacidade de financiamento e são capazes de oferecer taxas de juros substancialmente inferiores às praticadas no mercado interno e prazos de pagamento bastante longos (acima de 360 dias), enquanto no mercado doméstico, as vendas são realizadas à vista. A presença oligopolística dessas empresas no cenário internacional faz com que o algodão transacionado nesse mercado não possa ser relacionado a nacionalidades (Gonçalves, 1997).

A Figura 5 mostra o valor das importações brasileiras de algodão em pluma durante o periodo 1992 a 1999, segundo a forma de pagamento. De 1992 até 1994, predominaram os financiamentos com prazo de pagamento de até 180 dias. Essa modalidade de pagamento representou, nos anos de 1992, 1993 e 1994, respectivamente 78\%, $86 \%$ e $77 \%$ do valor das importações financiadas de algodão em pluma.

Nos anos de 1995 e 1996, a maior parte do valor total das importações brasileiras dessa fibra (53\% e $72 \%$, respectivamente) foi financiada com prazo de pagamento de 181 a 360 dias. Naqueles anos, respectivamente, apenas $0,07 \%$ e $0,01 \%$ do total das importações não foram financiadas. Em 1996, embora representando um percentual inexpressivo em relação ao total (cerca de 0,5\%), surgem as importações de algodão em pluma com prazo de financiamento superior a 360 dias. 


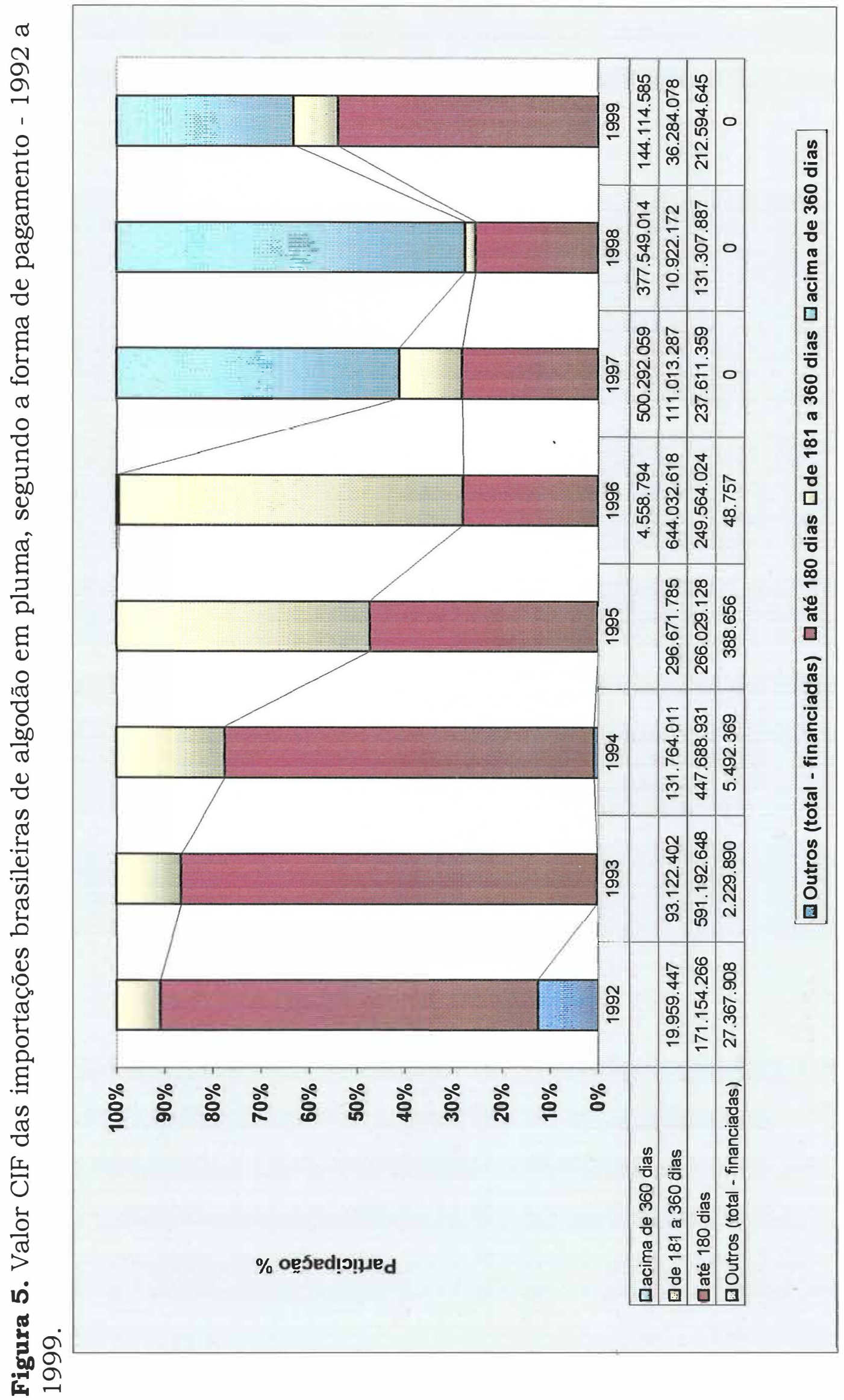

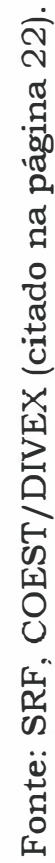


Na safra 1996/97, observou-se a menor produção nacional de algodão em pluma durante a década de noventa. As importações brasileiras dessa fibra atingiram valores sem precedentes e contribuíram expressivamente para o saldo negativo da balança comercial brasileira naquele ano.

Visando coibir os efeitos das condições de financiamento externo sobre os preços do algodão em pluma nacional, o Banco Central do Brasil adotou, em 25 de março de 1997, a Medida Provisória $n^{\circ}$ 1.569/97, a qual entrou em vigor para contratos fechados após 31 de março de 1997. Tal Medida exigia, para as importaçōes com prazo de financiamento até 360 dias, o fechamento do câmbio no dia imediatamente posterior ao desembarque da mercadoria e o não cumprimento dessa regra implicava na imposição de multa aos importadores.

Não obstante, essa medida de restrição às importações mostrou-se ineficaz, pois o mercado internacional rapidamente passou a oferecer prazos de financiamentos mais dilatados aos importadores brasileiros. Em 1997, as importaçōes financiadas para pagamento acima de 360 dias representaram $59 \%$ do valor total importado pelo Brasil naquele ano. Em 1998, 73\% do valor das importações brasileiras de algodão foi adquirido sob essa forma de pagamento e 25,3\% com prazo de pagamento de até 180 dias.

Em 1999, as importaçōes diminuíram e a forma de pagamento com prazo acima de 360 dias representou 36,7\% do valor total importado, enquanto o financiamento até 180 dias foi a forma de pagamento mais utilizada, respondendo por $54 \%$ do valor das aquisições de algodão em pluma no mercado internacional.

Comparativamente ao ano de 1998, houve um aumento na participação dos financiamentos até 180 dias no valor total importado 
em 1999. Essa redução no prazo de pagamento pode estar relacionada à incerteza quanto aos efeitos da adoção do sistema de taxas de câmbio flutuantes desde janeiro de 1999.

No que tange ao comportamento das taxas de juros praticadas nos mercados interno e externo, o mesmo pode ser observado na Figura 6, a qual mostra a evolução das taxas de juros nesses mercados, bem como dos indices de taxa real de câmbio para o periodo 1993 a 1999.

As taxas representativas do mercado interno são a taxa líquida real do $\mathrm{CDB}$ e o custo efetivo real do financiamento de capital de giro, ambos pré-fixados para 30 dias. A taxa de juro no mercado internacional é representada pela Libor, que pode ser considerada a referência minima para o custo de captação de recursos externos.

Nota-se que há um grande diferencial entre as taxas de juros nos mercados interno e externo, principalmente considerando-se o custo de financiamento do capital de giro para as empresas, o qual apresenta taxas bastante superiores ao juro real oferecido pelas aplicações em $\mathrm{CDB}$ no país. Além disso, as taxas de juros no mercado interno apresentam grande variação, comparativamente aos movimentos da Libor, a qual manteve-se entre $5 \%$ e $7 \%$ ao ano, durante o periodo de 1993 a 1999.

As vantagens relativas às taxas de juros e prazos de pagamento no mercado externo são um estímulo adicional à necessidade de aquisição de matéria-prima pela indústria e podem estar fazendo com que a importação do algodão em pluma funcione mais como uma forma de financiar o capital de giro das empresas do que de adquirir o produto. 


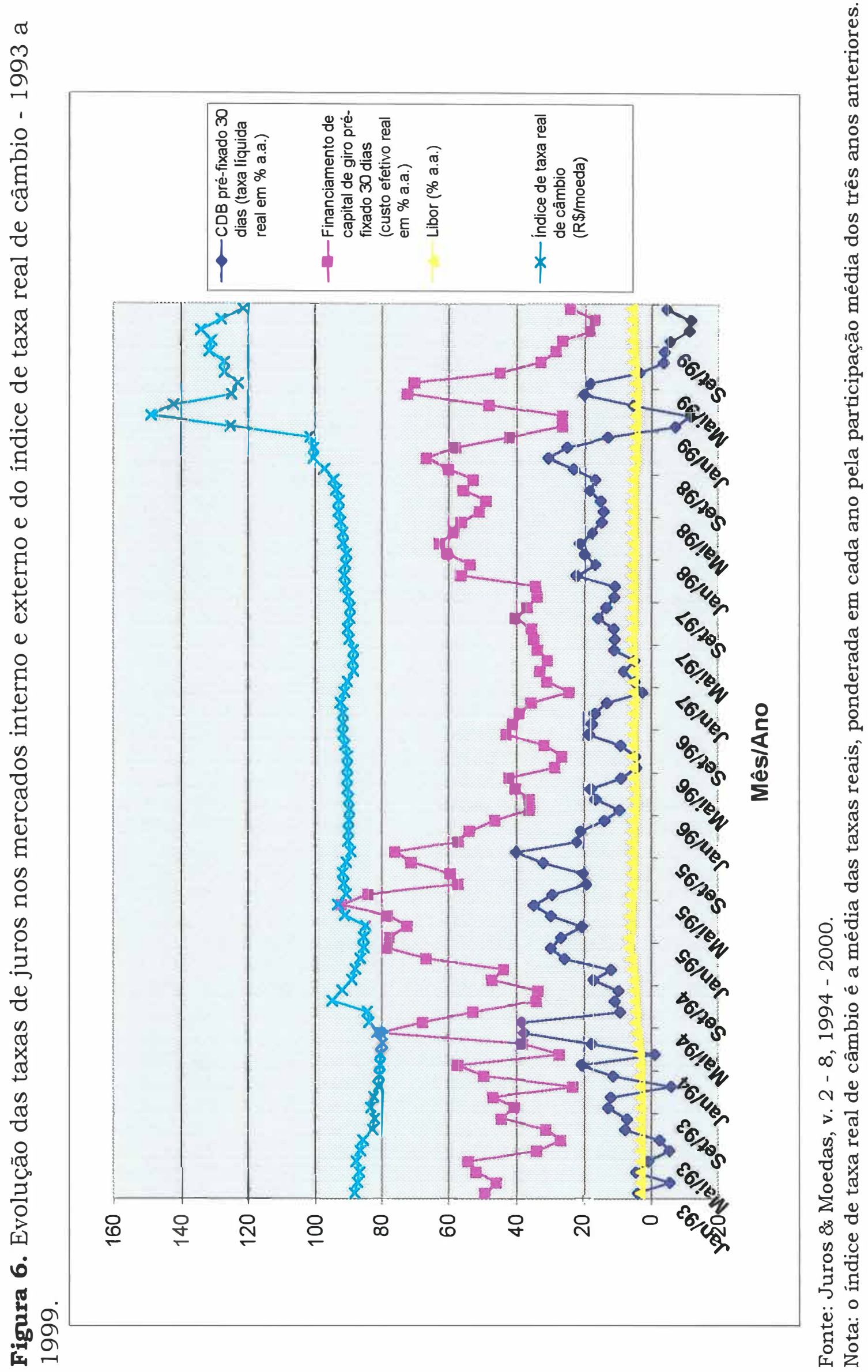


As empresas, contando com prazos de pagamento dilatados e taxas de juros substancialmente inferiores às vigentes no mercado interno, podem financiar o capital de giro via aquisição de algodão em pluma no mercado externo e desfrutar da vantagem de obter significativos retornos financeiros, aplicando os recursos da venda de seu produto final, antes de saldar a compra da matéria-prima (Gonçalves, 1997).

Nesse caso, as importações de algodão em pluma estariam mais vinculadas à arbitragem das taxas de juros interna e externa e menos à aquisição da fibra pelas indústrias. De acordo com Urban et al. (1995), as empresas reconheceriam que não compram apenas algodão em pluma importado, mas também os beneficios financeiros da transação.

Então, ainda que a produção nacional fosse suficiente para suprir o mercado interno, o que não ocorre atualmente, é questionável se as empresas brasileiras deixariam de adquirir o produto no mercado internacional, a persistirem essas condições de financiamento. Essas operações estariam afetando o potencial de desenvolvimento do mercado futuro de algodão no Brasil porque reduzem a demanda por hedging sob dois aspectos.

Primeiro, porque as condições favoráveis de importação no mercado externo podem estar proporcionando retornos financeiros de tal magnitude aos importadores, que estes acabam por não dar importância ao risco de preço e à necessidade de hedge para a matéria-prima adquirida externamente. Caso a arbitragem das taxas de juros interna e externa seja o foco principal das importações de algodão em pluma, é possivel que a administração do risco de preço desse produto torne-se uma questão secundária para os agentes. Em segundo lugar, porque a origem do produto (nacional ou importado) pode implicar em necessidades diferentes quanto à administração do risco de preço. 
Uma vez que a maior parte dos contratos de importação são fechados com grande antecedência e preço já fixado, o risco relativo à taxa de câmbio torna-se o fator central a ser considerado nessa operação. Nesse contexto, o hedge de moeda deveria ser a preocupação central dos importadores de algodão em pluma.

No caso dos contratos de importação com preço a fixar, a realizaçāo do hedge de preço para o produto importado torna-se relevante. Entretanto, se os preços doméstico e internacional do algodão em pluma evoluírem independentemente no curto prazo, o hedge de preço no Brasil pode não ser eficaz para o produto adquirido no mercado externo. Essa situação afetaria diretamente a demanda pelos contratos da $B M \& F$ e, consequentemente, o potencial de desenvolvimento do mercado futuro de algodão no Brasil.

Além disso, com o processo de liberalização da economia durante a década de noventa, espera-se que os mercados doméstico e internacional de algodão em pluma apresentem-se integrados e seus preços mantenham uma relação estável no longo prazo (Figura 1). A existência de uma relação de longo prazo entre esses preços constitui-se em condição necessária, mas não suficiente para o hedging (Arbex \& Carvalho, 1999). Para a realização das operaçōes de hedge, as relaçōes de preço relevantes são as de curto prazo.

Entretanto, condições conjunturais e regionais podem levar os preços domésticos e internacionais dessa fibra a não caminhar conjuntamente no curto prazo. Caso os preços doméstico e internacional do algodão em pluma não evoluam de forma conjunta no curto prazo, o contrato futuro de algodão da $B M \& F$ deve ser, teoricamente, um instrumento de administração de risco de preço mais eficaz do que o da NYCE, para o produto brasileiro. 
Todavia, as condições favoráveis de financiamento no mercado internacional podem estar afetando o potencial de desenvolvimento do mercado futuro dessa commodity no Brasil porque os ganhos financeiros obtidos com as importações de algodão podem estar fazendo com que os importadores não levem em conta o risco de preço do produto importado.

Isso não significa, porém, que os agentes brasileiros que atuam na comercialização do produto, ainda que importado, não devam procurar mecanismos de redução do risco de preços. A possibilidade de administrar esse risco é uma característica fundamental dos modernos mercados de commodities, inclusive agrícolas. A redução da incerteza de preços transmite-se através da cadeia de comercialização, com efeitos benéficos até o setor produtivo primário.

\subsection{O destino das importações brasileiras de algodão em pluma}

A importação de algodão em pluma não se distribui de maneira homogênea pelo Brasil. Devido à crise de sua cotonicultura, o estado de São Paulo passou a depender de volumes crescentes de algodão importado na década de noventa.

Como a produção paulista tornou-se insuficiente para abastecer seu parque de fiação, as vantagens de custo dessas indústrias foram eliminadas pela abertura comercial, que extinguiu a tarifa aduaneira cobrada sobre o algodão importado e que protegia o produto nacional. Essa realidade, aliada à oferta de incentivos fiscais e creditícios e à disponibilidade de mão-de-obra à custos mais baixos, tem deslocado o parque de fiações paulista para outros estados nos últimos anos (Gonçalves, 1997). Atualmente, as fiações brasileiras concentram-se principalmente nos estados de São Paulo, Ceará, Minas Gerais e Santa 
Catarina, o que os torna grandes consumidores do produto, tanto nacional quanto importado.

A Figura 7 mostra o percentual das importações brasileiras de algodão em pluma destinado a cada região, segundo o porto de entrada, nos anos de 1992 a 1999. Pode-se observar que, em 1992, a quase totalidade do algodão importado era desembarcada em portos do Sul e Sudeste, atendendo o consumo da fibra nessas regiões. Contudo, a partir de 1993, essa situação começou a se alterar, com aumento substancial do percentual de algodão em pluma importado pela região Nordeste, especialmente a partir de 1997.

Figura 7. Percentual das importações brasileiras de algodão em pluma destinado a cada região, segundo o porto de entrada - 1992 a 1999.

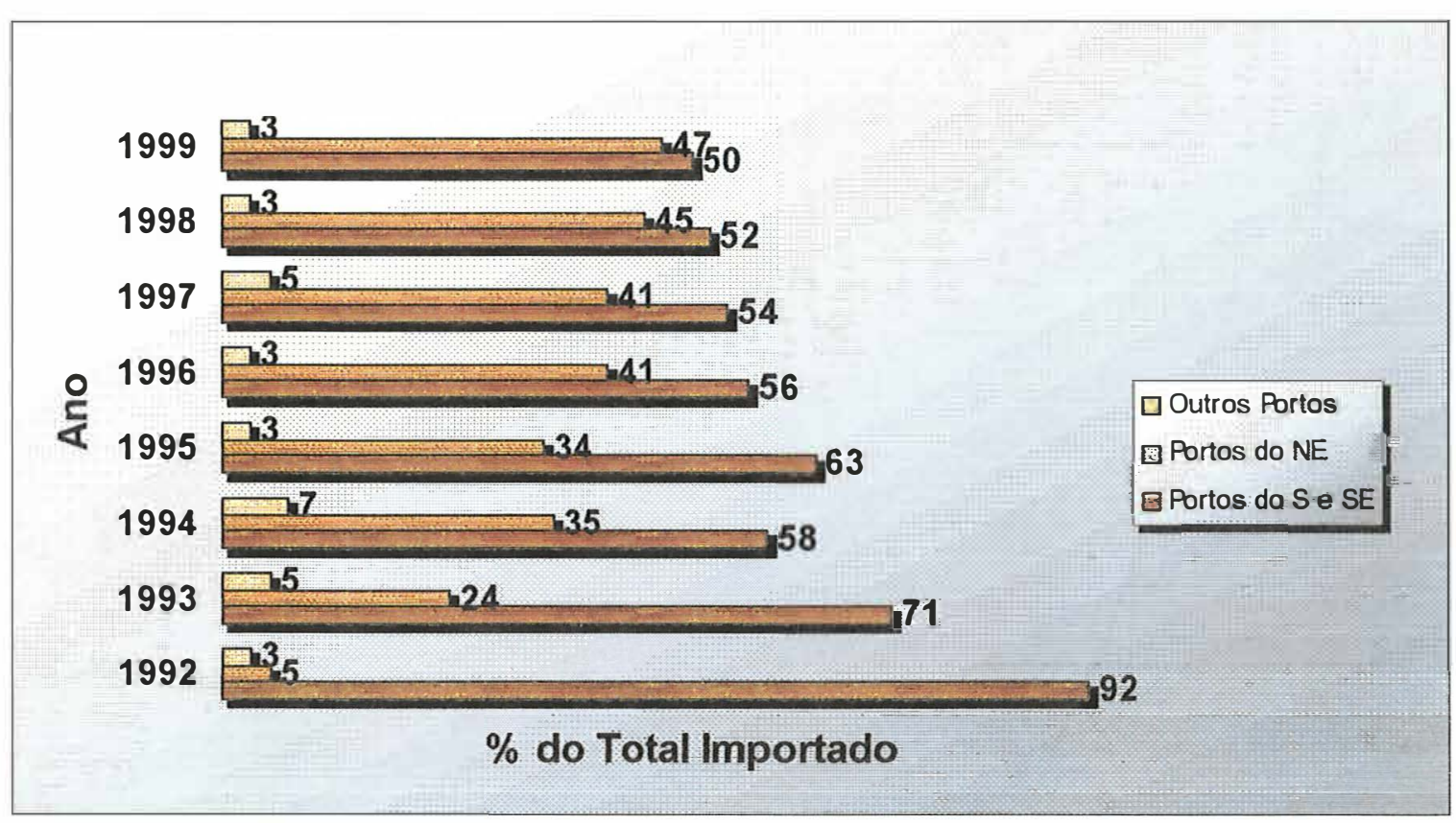

Fonte: SRF, COEST/DIVEX (citado na página 22).

Nota: Elaboração do autor, considerando-se apenas os portos com entradas acima de $1 \%$ do total importado. Os portos das regiòes Sul e Sudeste considerados para o cálculo dos percentuais foram: Porto de Vitória, Porto de Santos, Paranaguá, Foz do Iguaçu, Itajaí e Uruguaiana. Na regiāo Nordeste, os portos considerados foram: Porto de Recife, Fortaleza, Cabedelo e Natal. 
Tal fato pode estar relacionado ao aumento da produção cotonícola no Centro-Oeste do país desde então e ao deslocamento do parque de fiações para os estados da região Nordeste. O algodão cultivado no Brasil Central estaria sendo destinado às regiões Sul e Sudeste, pela proximidade espacial com os principais centros consumidores do produto, quais sejam, estados de São Paulo, Minas Gerais e Santa Catarina. Além disso, o aumento do número de empresas de fiação e tecelagem e a deficiência no abastecimento de algodão em pluma na região Nordeste provavelmente estão contribuindo para o crescimento das importações destinadas àquela região.

Em 1999, metade das importações brasileiras de algodão em pluma entraram no país através de portos das regiões Sul e Sudeste, enquanto a outra metade desembarcou em portos da região Nordeste. Esse cenário mostra-se bastante distinto daquele observado no início da década. 


\section{OS MERCADOS FUTUROS}

A evoluçāo histórica dos mercados futuros, tanto no contexto mundial como nacional, mostra o surgimento de novos contratos mediante transformações econômicas e estruturais, as quais criaram condições para que novos instrumentos fossem demandados e seus mercados desenvolvidos. As negociações futuras, organizadas e não organizadas, desenvolvem-se gradualmente, evidentemente para suprir necessidades específicas do mercado (Irwin ${ }^{9}$, citado em Williams, 1998).

\subsection{A evolução dos mercados futuros no mundo}

Os mercados futuros modernos têm sua origem nas negociações de arroz, no Japāo feudal do século XVIII. Os recibos de arroz, reconhecidos legalmente por volta de 1730, envolviam padronizações especificando prazo, pagamento, quantidade e qualidade para entrega futura (forward contracts - contratos à termo). Esses recibos eram amplamente negociados na Bolsa de Arroz de Osaka e aceitos como moeda corrente.

Esses contratos à termo surgiram com o objetivo de atenuar os problemas para a comercializaçāo das safras, decorrentes da sazonalidade dos produtos agricolas. A colheita era realizada apenas

\footnotetext{
${ }^{9}$ IRWIN, H.S. Eyolution of futures trading. Madison, WI: Mimir Publishers, 1954.
} 
uma vez ao ano, mas a matéria-prima era demandada por consumidores e processadores ao longo de todo o ano. Entretanto, o excesso de produto na safra e escassez na entressafra gerava oscilações inevitáveis nos preços dos produtos, as quais levavam ao eventual não cumprimento do contrato.

Nessa situação de instabilidade, fazia-se necessário transferir o risco das oscilações de preços dos setores produtivos para os segmentos não produtivos, que dispusessem de capital para assumir os riscos da produção, em troca da obtenção dos lucros potenciais resultantes. Surgiram assim, os contratos to arrive (para quando chegar), que fixavam o preço da mercadoria desde a sua produção até a entrega final.

Esses contratos foram negociados primeiramente na Europa, no Centro de Algodão de Liverpool, em 1878. Apesar de ser acertado individualmente, esse tipo de contrato foi negociado durante muitos anos e direcionou o Ocidente ao modelo atual de negociação futura (Teixeira, 1992).

Nos Estados Unidos, as operações a futuro começaram em meados do século XIX. Em 1848, foi constituida a Chicago Board of Trade (CBOT) - hoje a maior Bolsa de futuros do mundo - onde eram realizadas negociações à vista e à termo. Fundada algumas décadas depois, a Chicago Mercantile Exchange (CME) juntamente com a CBOT, estiveram por trás das melhorias na infra-estrutura da comercialização de grãos nos Estados Unidos. Integra também a lista das Bolsas pioneiras desse pais, a New York Cotton Exchange (NYCE), fundada em 1870 para facilitar a negociação dos contratos futuros de algodão. A partir da consolidação dessas Bolsas e das experiências japonesa e européias foi se delineando a atual indústria de futuros no mundo (Forbes, 1994). 
$\mathrm{Na}$ década de 1930 iniciaram-se as negociações de futuros de metais (cobre, prata, estanho e outros) ${ }^{10}$ e posteriormente, no início dos anos 50, tornaram-se disponiveis os futuros de produtos agrícolas processados (farelo e óleo de soja). Na década de 1960, teve início uma nova onda de inovações com a introdução dos futuros de commodities pereciveis (livestock). Assim, durante muito tempo, os mercados futuros foram referenciados apenas em commodities agrícolas e não agrícolas.

Durante a década de 1970, entretanto, o mundo testemunhou profundas mudanças econômicas e as Bolsas de futuros estiveram na linha de frente da expansão dos mercados financeiros. Em agosto de 1971, foi encerrado o tratado de Bretton Woods, pelo qual as emissões de moeda deveriam guardar uma relação com o lastro em ouro mantido pelos países. Foi então criado o Fundo Monetário Internacional (FMI), que estabeleceu os Direitos Especiais de Saque (Special Drawing Rights - SDR) para garantir a estabilidade monetária internacional. Entretanto, esse instrumento mostrou-se insuficiente para cumprir seu papel, o que permitiu o lançamento, em 1972, dos contratos futuros de moedas estrangeiras.

A partir daquele ano, o descontrole monetário atingiu grande parte das economias e a volatilidade das taxas de juros proporcionou às Bolsas de futuros introduzirem, em 1975, um novo instrumento de administração de risco - os futuros de taxas de juros - e posteriormente os futuros de Notas do Tesouro (Treasury-bill).

\footnotetext{
10 No início da década de 1930, durante a Grande Depressão, foi proibida a propriedade privada de ouro nos Estados Unidos, por causa da crise econômica nacional. Essa proibição durou até 31 de dezembro de 1974 e logo depois foi lançado o contrato futuro daquele metal.
} 
Em 1978, começaram a ser negociados os futuros de heating oil, favorecidos pelo enfraquecimento da OPEP no controle do mercado mundial de petróleo. Com o tempo, surgiram vários futuros de energia como petróleo cru, eletricidade, gás natural e outros.

Até então, os contratos futuros de moedas, ouro, taxa de juros e energia adotaram e adaptaram o mecanismo de entrega fisica utilizado para os futuros de grãos. A possibilidade de entrega física assegura a convergência entre os preços à vista e futuro, possibilitando a utilização dos contratos futuros como instrumento de hedge.

Em 1981, a introdução do contrato futuro de Eurodollar trouxe consigo uma inovação, que foi a liquidação financeira. Ao invés de exigir entrega física para liquidar o contrato, a obrigação era liquidada no último dia de negociação pela diferença entre uma série de preços à vista independente e amplamente aceitável e o preço futuro do contrato. Esse procedimento possibilitou que os contratos futuros fossem utilizados como instrumento de hedge para novos produtos inclusive aqueles com entrega muito custosa. O mais notável desses produtos foi o futuro de índices de açōes, introduzido em 1982, seguido pelas opçōes sobre contratos futuros.

Assim, os objetivos dos agentes envolvidos nas negociaçōes com futuros têm sofrido modificaçōes desde a origem desse mercado. No início, o mesmo era utilizado para viabilizar a entrega da mercadoria, mas evoluiu gradualmente até transformar-se num veículo para o gerenciamento de riscos. Atualmente, menos de $2 \%$ dos negócios são concretizados com a entrega física da mercadoria (Marques \& Mello, 1999, p.51). 


\subsection{A evolução dos mercados futuros no Brasil11}

O desenvolvimento do mercado futuro no Brasil começou em 1917 com a fundação da primeira Bolsa de commodities agrícolas, a Bolsa de Mercadorias de São Paulo (BMSP). Ao final da I Guerra Mundial, a economia vivia um ambiente de profundas transformações e é nesse cenário que a BMSP procurou se consolidar.

A crise na economia cafeeira brasileira, desencadeada por surtos de superprodução desde 1909, fez com que o capital começasse a migrar para a atividade fabril. Em 1920, 31\% da indústria brasileira estava sediada em São Paulo, com destaque para as indústrias têxteis. A produção de algodāo no país era crescente e havia necessidade de matéria-prima padronizada, classificada, em condições de oferta satisfatória e niveis de preço previsiveis. Esses fatores propiciaram condições para a expansão do mercado futuro de algodão no Brasil.

De acordo com a história da BMSP (1987, p. 109)

"os negócios com algodão na BMSP datam de 1918, atendendo a uma necessidade do mercado, gerada por dois fortes motivos: a demanda da Europa, que ressentia da falta de matéria-prima no pós-guerra; e a expansão da lavoura algodoeira em São Paulo (...)".

Os contratos futuros de algodāo e açúcar impulsionaram os negócios da BMSP na década de 20 , sendo negociados no pregão, uma média de 60 mil toneladas de algodāo por ano. Entretanto, ao longo desse periodo, a trajetória do mercado futuro de algodão no Brasil

"A parte inicial desta seção baseia-se em BMSP (1987). 
sofreu alguns sobressaltos, decorrentes das transformaçōes estruturais e setoriais da economia brasileira e mundial.

A queda dos preços internacionais do café durante a década de 1920 levou o governo a acumular estoques superiores a 10 milhões de sacas. Além disso, previsões de uma safra recorde de café em 1929/30 e o crash da Bolsa de Nova York em outubro de 1929, desencadearam uma crise generalizada na economia brasileira, que atingiu severamente a indústria têxtil. O mercado algodoeiro foi fortemente afetado, o que levou ao enfraquecimento dos pregões da BMSP, cujo volume de algodão negociado caiu 90\% entre 1930 e 1932, comparativamente ao triênio anterior (BMSP, 1987).

A decadência do café impulsionou a policultura em São Paulo e o algodão ressurgiu com força admirável em meados da década de 1930. O pregão da BMSP começou a se recuperar a partir de 1935, ano em que foram negociadas 15,7 mil toneladas de algodão. Esse valor saltou para 35,3 mil toneladas em 1936, 53 mil toneladas em 1939 e mais de 150 mil toneladas em 1940.

A mudança na estrutura econômica do pais permitiu que a II Guerra Mundial alavancasse o desenvolvimento da economia brasileira. A indústria têxtil prosperou e os contratos de algodão se multiplicaram na BMSP. Em 14 de julho de 1931, o Decreto Federal 20.211 estabeleceu a obrigatoriedade de classificação pela BMSP, de todo algodão produzido no território nacional. Em 1941, o governo declarou a BMSP "órgão técnico e consultivo do poder público".

Contudo, nas duas décadas posteriores à II Guerra Mundial, o crescimento do Produto Interno Bruto (PIB) brasileiro (à uma taxa superior a $7 \%$ ao ano) ocorreu às custas de pressões inflacionárias e dificuldades no balanço de pagamentos. A economia algodoeira viveu 
um período de transição, caracterizado por forte concentração do mercado.

A produção de algodão, declinante desde 1946, a retração na demanda e a queda dos preços fizeram com que muitos beneficiadores deixassem a atividade. Assim, um pequeno número de grandes empresas passou a dominar a comercialização e a interferir na formação dos preços. Tal situação tornou evidente a vulnerabilidade dos pregões da BMSP, dependentes de um único produto ${ }^{12}$. O pior desempenho daquela Bolsa, desde 1935, ocorreu em 1953, quando foram negociadas no pregão apenas 5 mil toneladas de algodão.

Na segunda metade da década de 1950, a BMSP estudou a possibilidade de criação dos mercados futuros de cacau, mamona e café. A tentativa de diversificação objetivou ampliar o espaço das negociaçōes futuras no pais, pois as mudanças estruturais ocorridas na economia têxtil e algodoeira na década anterior, limitaram o desenvolvimento do mercado futuro desse produto no Brasil. Entre 1956 e 1959, foram negociadas cerca de 12 mil toneladas de algodão no mercado futuro da BMSP.

Nos períodos de 1951 a 1957 e de 1959 a 1966, o algodão foi alvo de medidas restritivas à exportação, impostas pelo governo, com o objetivo de garantir o abastecimento interno. Entretanto, nos anos de 1968/69 e 1969/70, as exportações brasileiras de algodão representaram $10,8 \%$ do total exportado no mundo, apesar da quebra na produção decorrente de fatores climáticos.

Em 1973, medidas mais rigorosas de controle sobre as exportações foram adotadas. O marco inicial da queda acentuada nas exportações brasileiras de algodão foi 1974. A intervenção do Estado no

\footnotetext{
12 Apesar disso, a BMSP consolidava cada vez mais seu papel no suporte técnico ao comércio de algodão, através da padronização e classificação do produto em seus laboratórios.
} 
mercado algodoeiro, impondo restrições às exportações (e interferindo na formação dos preços), durou até 1988, quando foi implementada a Resolução número 155, que liberou as exportações de algodão em pluma de restrições quantitativas e qualitativas e previu a redefinição da alíquota do imposto de importação, de forma a compatibilizar as tendências de preços nos mercados doméstico e internacional (Barbosa, 1996).

A sistemática presença do governo no mercado de algodão, os ciclos de crescimento e as mudanças estruturais ocorridas na economia após 1950, foram desfavoráveis ao desenvolvimento satisfatório do mercado futuro dessa commodity, que permaneceu quase inativo depois de importantes avanços no sentido de sua consolidação ${ }^{13}$. Entretanto, nos anos que se seguiram a 1964, ocorreram transformações econômicas, que criaram condições para o surgimento de novos mercados futuros.

A reforma financeira, iniciada em 1964 com a Lei Bancária, bem como a modernização do mercado de capitais (1965/66), através da introdução da correção monetária, tornaram atrativos os investimentos em aplicações a prazo no país, gerando liquidez na economia e impondo novos padrões de competitividade ao mercado futuro, a fim de que ele pudesse se desenvolver.

No período 1968 a 1974, o país experimentou elevados índices de crescimento do seu produto. A economia operava a plena capacidade, mas muito dependente do capital externo para suprir a demanda por insumos e bens de capital. Entre 1974 e 1979, o enorme aumento das importações relativamente às exportações e a ampliação da dívida externa expuseram o país aos riscos e turbulências do mercado externo.

13 Os contratos futuros de algodão da BMSP tiveram seus picos de negociação em 1922, com 14 mil contratos, em 1941, com 43 mil contratos e em 1946, com 78 mil contratos negociados (BMSP, 1987). 
A internacionalização da economia brasileira criava condições para o desenvolvimento do mercado futuro contra os riscos cambiais.

Em 1986, foi fundada a Bolsa Mercantil \& de Futuros, um projeto desenvolvido pela Bolsa de Valores de São Paulo (Bovespa), visando a implantação de uma Bolsa de futuros nos moldes internacionais. Nessa época, a indústria de futuros no Brasil era pouco ativa, mas, alavancada pelos contratos de câmbio, a Bolsa Mercantil \& de Futuros logo transformou-se no maior centro de contratos futuros e de opções da América Latina e inseriu-se entre as principais Bolsas do mundo (Teixeira, 1992).

Já no primeiro levantamento oficial de suas atividades, referente ao periodo entre 31 de janeiro de 1986 e 31 de julho de 1987, a Bolsa Mercantil \& de Futuros despontou como a maior do pais, com $71,5 \%$ do mercado de futuros no Brasil. Então, na tentativa de consolidar o mercado futuro de commodities agropecuárias, essa Bolsa lançou, ao longo do ano de 1987, os contratos futuros de frango, boi gordo e porco (Ferreira \& Horita, 1996).

Até o início da década de 1990, os contratos futuros de produtos agropecuários eram operados em duas Bolsas: na BMSP e na Bolsa Mercantil \& de Futuros. Entretanto, durante a segunda metade da década de oitenta, esse mercado não se desenvolveu a contento. Nesse periodo, os programas de ajustamento para o controle da inflação, iniciados em 1986 com o Plano Cruzado, e as perturbações no quadro político do país geraram um cenário de instabilidade na economia brasileira.

Em 1991, houve a fusão entre a Bolsa Mercantil \& de Futuros e a BMSP, dando origem à Bolsa de Mercadorias \& Futuros (BM\&F) onde são negociados atualmente os futuros de ativos financeiros e de produtos agropecuários. Em 1997, ocorreu uma nova fusão, desta vez 
com a Bolsa Brasileira de Futuros (BBF), fundada em 1983 e sediada no Rio de Janeiro. Através dessa união, a BM\&F consolidou-se como virtual centro nacional de commodities e principal centro de negociação de derivativos do MERCOSUL (Marques \& Mello, 1999). Considerando-se o volume de contratos negociados em 1999, a BM\&F é a décima maior Bolsa de derivativos do mundo. A Figura 8 mostra a evolução do volume de contratos futuros e de opções negociados na $B M \& F$, no periodo de 1996 a 1999.

Pode-se observar através da Figura 8 que, durante o periodo de 1996 a 1999, houve uma queda no volume total de contratos negociados na BM\&F. Em 1996, foram negociados 134,6 milhões de contratos, enquanto o equivalente em 1997 ficou em 122,2 milhões. Em 1998, o volume de contratos negociados caiu para 87 milhões e, em 1999, foram negociados 55,9 milhões de contratos.

Os ativos financeiros respondem, desde a criação da BM\&F, pela maior participação no volume total negociado nessa Bolsa. Observa-se pela Figura 8 que, durante o periodo considerado, os futuros sobre taxas de juros, taxas de câmbio, swaps e indice de ações foram os mais negociados. Entre 1996 e 1999, os referidos mercados tiveram, respectivamente, uma participação média de 37,5\%, 37,5\%, 6,4\% e $11,4 \%$ no volume total negociado.

Com relação aos agrícolas, estes representam um percentual muito pequeno no volume total de contratos negociados na BM\&F, comparativamente à participação dos ativos financeiros. Entretanto, a participação dos futuros agropecuários no volume total negociado naquela Bolsa vem crescendo ano a ano, passando de 0,25\% em 1996 para 0,44\% em 1998 e para 1\% em 1999. Até 1999, eram negociados na BM\&F os contratos agropecuários de açúcar cristal, algodão, boi gordo, café arábica, milho e soja. Em 31 de março de 2000, foi lançado o 


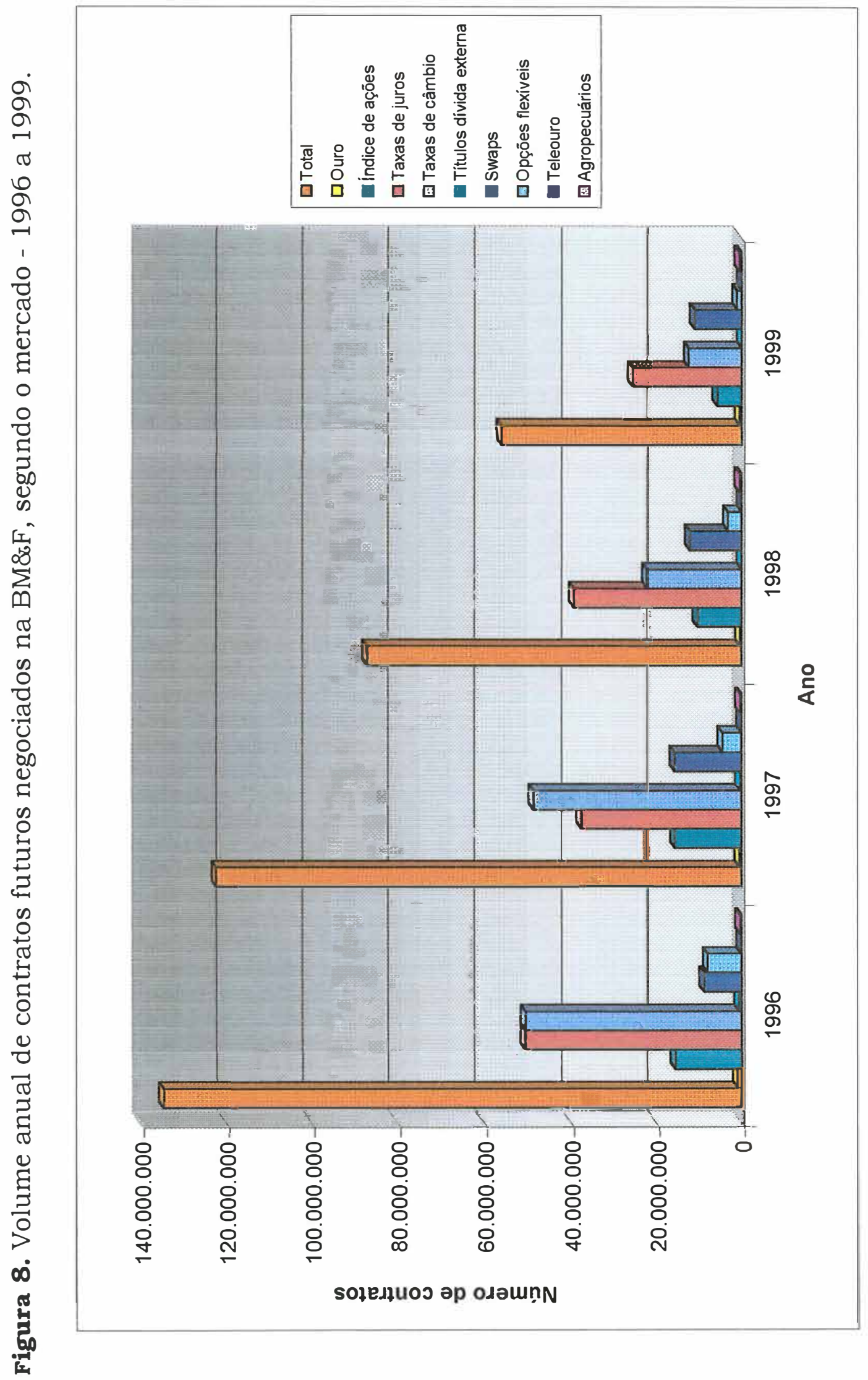

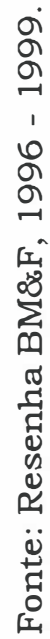


contrato de álcool anidro carburante, primeiro contrato de energia no Hemisfério Sul.

Através da Figura 9, pode-se observar a participação de cada um desses produtos no volume total de agropecuários negociados no periodo 1996 a 1999. Nota-se que as commodities mais negociadas na BM\&F no periodo foram café arábica e boi gordo, respectivamente. O primeiro produto teve aumentada a sua participação no total de agropecuários negociados no periodo, enquanto para o segundo, a mesma diminuiu.

Figura 9. Volume de contratos futuros agropecuários negociados na BM\&F - 1996 a 1999.

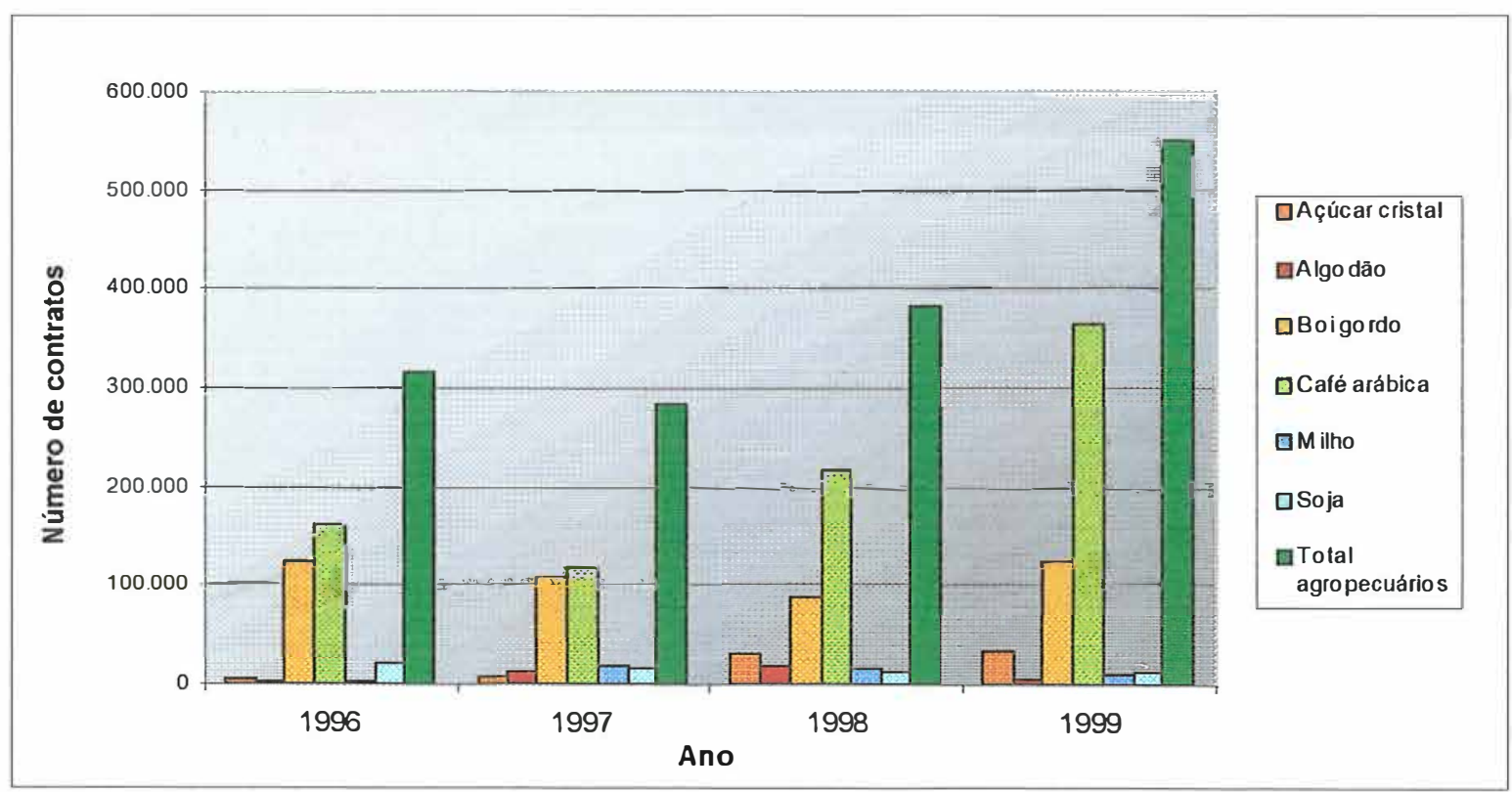

Fonte: Resenha BM\&F, 1996 - 1999.

Os contratos futuros de café arábica representaram 50,7\% do volume total de agropecuários negociados em 1996 e, em 1999, essa participação atingiu $66,2 \%$. Em 1996, os contratos futuros de boi gordo responderam por 39\% das negociações futuras de commodities agricolas na BM\&F, mas em 1999 por apenas 22,4\% (Figura 10). 


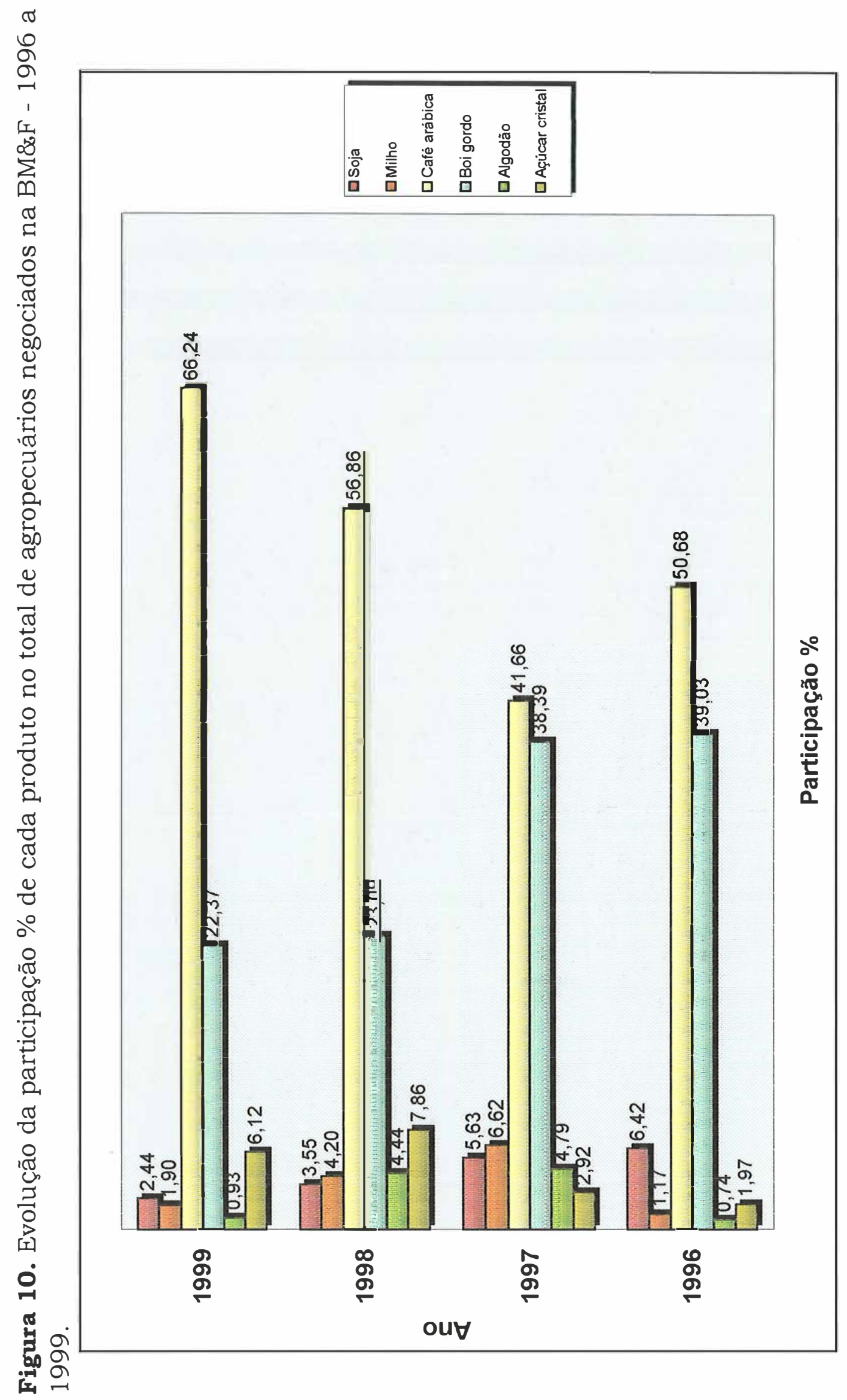

बं 


\subsection{O mercado futuro de algodão em pluma}

Desde o início da década de 1990, quando intensificou-se o processo de abertura da economia brasileira, não havia, no Brasil, um mercado futuro de algodão em pluma, onde os importadores pudessem transferir o risco de preço para os especuladores. Dessa forma, o risco dos contratos de importação poderia originar-se da variação de preço do produto entre a contratação da importação e sua efetiva utilização e da variação da taxa de câmbio.

O risco cambial pode ser administrado, pois no Brasil já existe, desde 1986, um mercado futuro de moedas bem estruturado, na Bolsa de Mercadorias \& Futuros (BM\&F). Contudo, para reduzir o risco de preço, a saída encontrada por muitas empresas foi a realização do cross hegde na New York Cotton Exchange (NYCE), a principal Bolsa onde são negociados contratos futuros de algodão em pluma. O cross hedge é o hedging para mercadorias com características diferentes daquelas estabelecidas no contrato futuro. A preferência por esse tipo de operação na NYCE é um dos fatores que afeta o potencial de desenvolvimento do mercado futuro de algodão no Brasil.

Em 1996, a BM\&F relançou o contrato futuro cambial de algodão em pluma, cujos meses de vencimento são março, maio, julho, outubro e dezembro. Entretanto, esse fato é demasiadamente recente, para que se possa efetuar especulações sobre seu sucesso.

Pode-se observar através da Figura 11, a evolução do volume de contratos de algodão em pluma negociados na BM\&F desde o seu lançamento, em novembro de 1996, até dezembro de 1999. Nota-se que durante esse periodo, não houve liquidez expressiva nesse mercado. 
Figura 11. Volume de contratos futuros de algodão em pluma negociados na BM\&F - Novembro/1996 a Dezembro/1999.

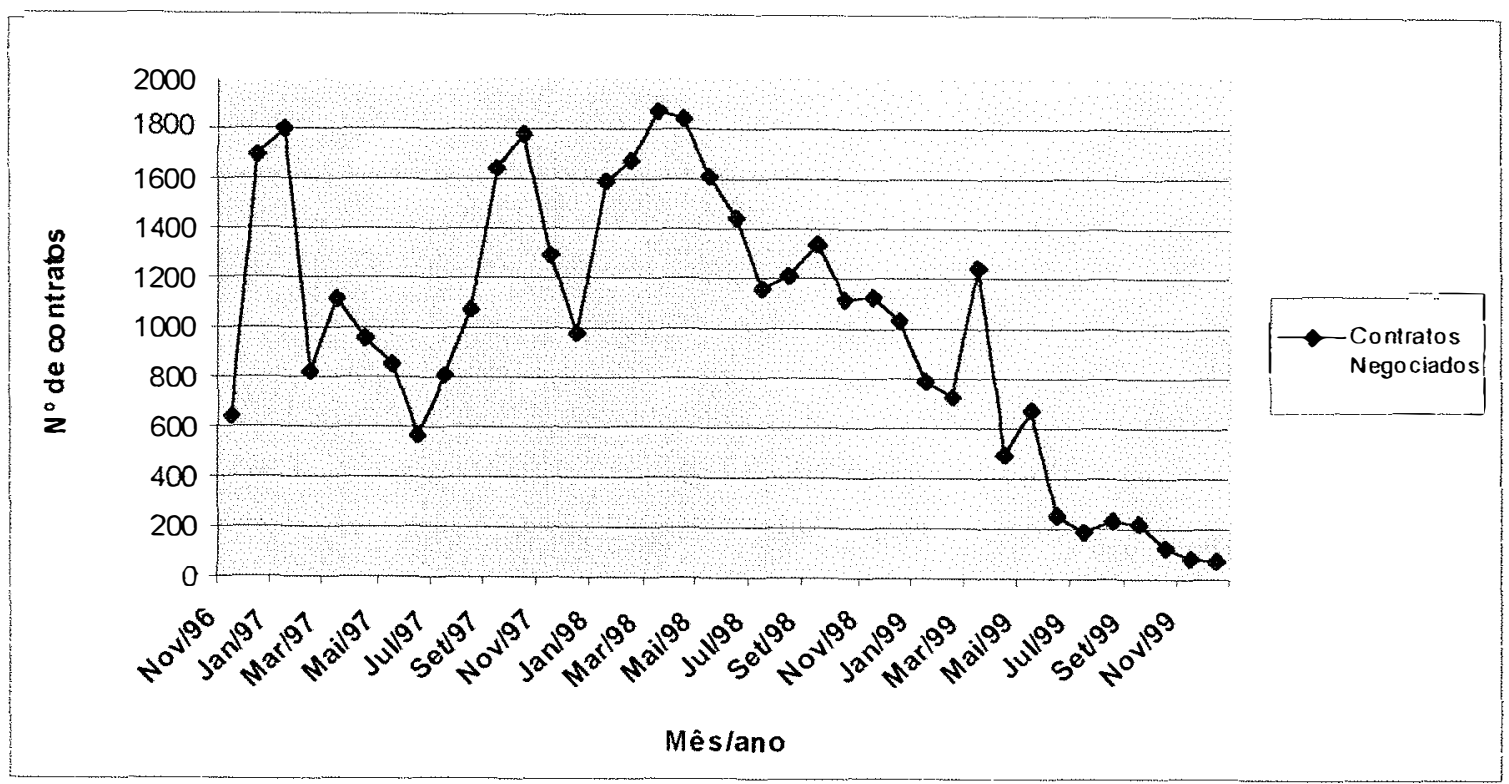

Fonte: BM\&F (2000b).

Nos meses de novembro e dezembro de 1996, foram negociados 2.339 contratos futuros de algodão em pluma. Durante os anos de 1997 e 1998, o número de contratos negociados foi crescente, passando para 13.689 e 17.007, respectivamente. Ainda que a liquidez desse mercado seja muito pequena frente a outras Bolsas internacionais, o número de contratos de algodão em pluma negociado na BM\&F entre esses dois anos aumentou cerca de 24,2\%. Entretanto, no ano de 1999, foram negociados 5.115 contratos, indicando uma redução de $70 \%$ em relação ao ano anterior.

Em março de 1999, a BM\&F promoveu uma mudança na forma de liquidação do contrato futuro de algodão em pluma. Desde o seu lançamento, em 1996, a liquidação do referido contrato era financeira, através de uma média de três dias do Indicador de preço do algodão em pluma ESALQ/BM\&F. A partir do contrato com vencimento em outubro de 1999, a liquidação passou a ser obrigatoriamente por entrega fisica. 
A nova forma de liquidação pode ter contribuído para a redução na liquidez do mercado futuro do algodão em pluma, uma vez que os agentes podem não conseguir sair de suas posições e acabar recebendo a mercadoria, principalmente em mercados com pouca liquidez ("thin markets"). Entretanto, são necessários estudos para que essa hipótese seja confirmada.

A falta de liquidez desse mercado pode levar os agentes a preferir utilizar (ou continuar utilizando) os contratos futuros da NYCE para se proteger das oscilações adversas no preço produto. Não obstante, essa estratégia não é isenta de problemas.

Os periodos de colheita nos hemisférios Norte e Sul são distintos: enquanto as safras brasileira ${ }^{14}$ e argentina (a Argentina é o principal exportador para o Brasil) concentram-se no primeiro semestre do ano, a safra norte-americana (principal produtor mundial) concentra-se no segundo semestre. Dessa forma, os preços internos e externos nem sempre evoluem conjuntamente, fato que pode comprometer a estratégia de hedge pelos importadores brasileiros.

A Figura 12 mostra a evolução diária dos preços futuros do algodão em pluma na BM\&F e na $\mathrm{NYCE}$, bem como as cotações do Indicador de Preço do Algodāo em Pluma na Cidade de São Paulo ESALQ/BM\&F (Indipluma) e a taxa de câmbio (R\$/US\$), durante o periodo de novembro de 1996 a dezembro de 1999.

14 Essa situação vem se modificando, pois o Mato Grosso, atualmente o principal estado produtor do país, concentra sua colheita no início do segundo semestre do ano. 


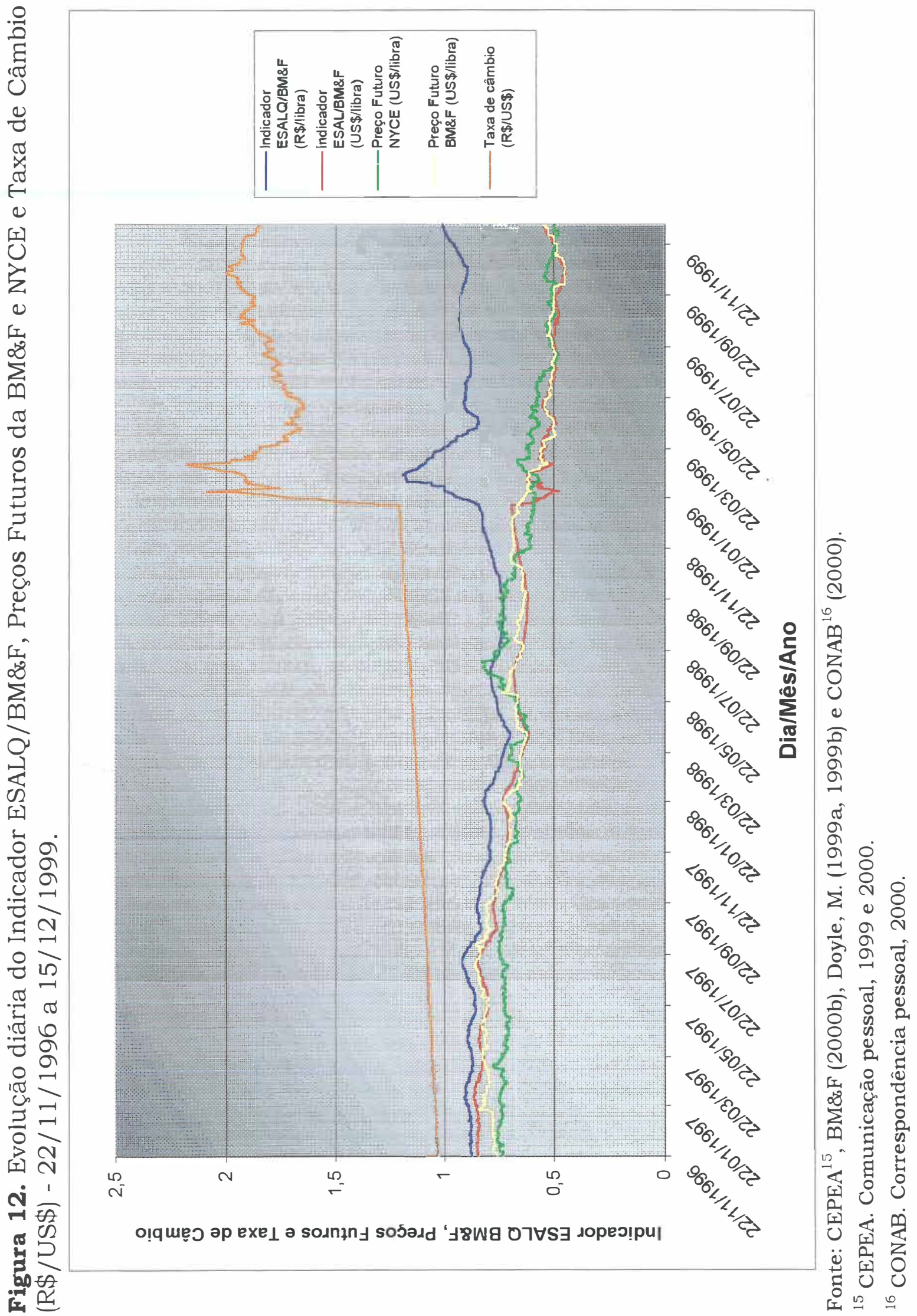


Além disso, o produto brasileiro e aquele negociado na NYCE não apresentam caracteristicas idênticas. Por essa razão, a operação realizada na NYCE para o algodão brasileiro é chamada de cross hedge e o risco adicional de preço que surge devido às diferenças qualitativas do produto deve ser cuidadosamente considerado na elaboração das estratégias de mercado.

Assim, as tentativas de reduzir o risco de preço do algodão em pluma no Brasil através da utilização de contratos futuros da $\mathrm{NYCE}$ podem não ser eficazes. Dessa forma, torna-se relevante comparar a efetividade dos contratos futuros de algodão em pluma da BM\&F e da NYCE como instrumentos de transferência de risco de preço, a fim de determinar qual a melhor alternativa de proteção para os agentes brasileiros. Sem dúvida, esse fator é de fundamental importância para analisar o potencial de desenvolvimento do mercado futuro de algodão no Brasil. 


\section{REVISĀO DE LITERATURA}

Na literatura sobre a análise do desenvolvimento bem sucedido de contratos futuros, existem dois enfoques tradicionais: um sobre as características da commodity e outro sobre as características ou desenho do contrato. O primeiro aborda os atributos considerados essenciais para que uma commodity seja negociada em mercados futuros, enquanto o segundo ressalta a importância do desenho do contrato para atrair o interesse dos agentes para o mercado, uma vez que a análise do sucesso de um contrato futuro está essencialmente vinculada à sua liquidez.

Tentando unificar esses dois enfoques, Black (1986) propôs uma importante variável para determinar o sucesso ou falência de um contrato, que é a presença ou ausência de um cross hedge eficiente para a commodity na qual se baseia o mercado futuro.

A possibilidade do cross hedge em diferentes Bolsas afeta a demanda pelo contrato futuro em questão e, consequentemente, a liquidez do mercado. Sob esse enfoque, os agentes decidirão pela realização do cross hedge, com base na avaliação do tradeoff entre o custo de liquidez e efetividade do hedge em cada mercado.

Além dos enfoques citados, existem outras formas de análise, que compreendem variáveis importantes para o desenvolvimento bem sucedido de um contrato, porque afetam a liquidez do mercado futuro. A análise de fatores relacionados a transformações econômicas são de 
grande importância porque eles alteram o cenário para o desenvolvimento desse mercado.

Os hedgers que usam contratos futuros como substitutos temporários para transaçōes no mercado físico estão preocupados com a efetividade do hedge, que é diretamente determinada pela relação entre os preços nos mercados à vista e futuro. A razão ótima de hedge pode ser estimada através de uma regressão do preço à vista contra preço futuro $^{17}$. Nessa regressão, a efetividade do hedge é dada pelo coeficiente de determinação e é tanto maior quanto maior a correlação entre os preços à vista e futuro.

Varangis et al. (1993) utilizaram o método de Minimos Quadrados Ordinários para estimar regressões e verificar se a realização do hedging de preço utilizando o contrato futuro de algodão em pluma na NYCE seria efetivo para dois tipos de algodão egipcio. Foram estimadas regressōes do logarítmo dos preços à vista do algodão egípcio na primeira diferença contra o logarítmo do preço à vista do algodão americano objeto do contrato da NYCE na primeira diferença.

Os resultados indicaram que não foi encontrada nenhuma relação entre o movimento de preços dos diferentes tipos de algodão egipcio e do algodão americano, objeto do contrato da NYCE. Os autores afirmam que a relação que interessa para os propósitos de hedging é a de curto prazo. Entretanto, partiram para a investigação da relação de longo prazo entre aqueles preços, através de análises de co-integração, a fim de identificar a existência de integração no mercado mundial de algodão. Os resultados dos testes de co-integração indicaram que a hipótese de relação de longo prazo entre os preços dos dois tipos de algodão egipcio e o preço do algodão norte-americano foi rejeitada.

${ }_{17}$ Os termos razāo ótima de hedge e eferividade de hedge serão definidos oportunamente no próximo capítulo. 
Os autores atribuíram os resultados encontrados ao fato de: a) os preços do algodão no Egito serem determinados pelo governo; b) os preços do algodão nos EUA serem afetados por políticas de suporte de preço e c) os tipos de fibras de algodão analisadas apresentarem características diferentes daquele estabelecido no contrato da NYCE (cross hedge). O estudo levou à conclusão de que o contrato $\mathrm{n}^{\circ} 2 \mathrm{da}$ NYCE não é um mecanismo apropriado de transferência de risco de preço para o algodão egípcio.

O estudo de Satyanarayan et al. (1993) também procurou analisar a possibilidade da utilização dos contratos futuros e de opções da NYCE como instrumento de administração de risco de preço do algodão em pluma, mas para os países francófonos da África (Benin, Burkina Faso, Camarões, República Centro-africana, Chade, Costa do Marfim, Mali, Senegal e Togo). Foram realizadas regressões das variações do preço à vista em cada país contra as variações do preço futuro para os dois contratos da NYCE: o $\mathrm{n}^{\circ} 2$ e o liquidado com base no Cotlook A Index. O percentual de variação no preço à vista não explicado pela regressão (1 $\mathrm{R}^{2}$ ) foi considerado pelos autores uma estimativa do risco de base.

Os resultados indicaram que o risco de base nas operações de hedge utilizando-se o contrato $\mathrm{n}^{\circ} 2$ da NYCE foram elevados, tendo como explicação o fato de tratar-se, na verdade, de uma operação de cross hedge. Com relação ao contrato liquidado com base no Cotlook $A$ Index, o risco de base foi consideravelmente menor. Entretanto, à época, esse contrato apresentava uma liquidez muito pequena, o que desencorajava sua utilização pelos agentes em suas estratégias.

Os autores desenvolveram ainda modelos de portfolio de hedging, no qual o problema era selecionar a razão ótima de hedge sob duas pressuposições comportamentais: minimização do risco e maximização da utilidade sob aversão ao risco. Os resultados indicaram que as 
operações de cross hedge (ex-ante) na NYCE apresentariam potencial de redução do risco de preço do algodão para os países francófonos da África.

Varangis et al. (1994) efetuaram uma análise semelhante àquela de Varangis et al. (1993), mas considerando países em desenvolvimento: Uzbequistão, Paquistão, China, Turquia e países francófonos da África. $\mathrm{Na}$ época em que foi realizado o estudo, esses países representavam cerca de $40 \%$ das exportações de algodão em pluma dos países em desenvolvimento.

Os autores utilizaram novamente o método de Minimos Quadrados Ordinários para estimar regressões dos preços à vista contra os preços futuros (ambos na primeira diferença) do contrato $n^{\circ} 2$ de algodão em pluma da NYCE e dos preços à vista contra o Cotlook $A$ Index. Da mesma forma que no estudo anterior, o risco de base com relação ao contrato $\mathrm{n}^{\circ} 2$ foi bastante elevado para todos os países, por tratar-se de um cross hedge e porque as politicas de preços americanas isolam o mercado dos Estados Unidos do mercado mundial de algodão.

Os resultados das regressões dos preços à vista contra o Cotlook $A$ Index (ambos na primeira diferença), indicaram que, para os países considerados exceto a Turquia, $70 \%$ a $85 \%$ das variações nos preços à vista seriam explicadas pelas variações do Cotlook $A$ Index. De acordo com os autores, esse resultado era esperado, por conta de os preços do algodão nos países considerados na análise entrarem com freqüência na composição do Cotlook A Index.

Adicionalmente, os autores desenvolveram a análise de portfolio de hedging, para alguns dos países em desenvolvimento (Uzbequistão, Paquistão, Turquia, China e países francófonos da África). Os resultados da seleção da razão ótima de hedge sob a pressuposição comportamental de minimização do risco indicaram que o hedging na 
NYCE apresentaria potencial de redução do risco de preço nos países selecionados.

Baffes \& Ajmad (1998) examinaram as relações de preço no mercado mundial de algodão e testaram para verificar se houve melhoria nas mesmas ao longo de uma década. Os autores afirmam que há pelo menos duas razões para esperar que as relações de preços tenham melhorado nesse periodo: a) a melhoria na tecnologia da informação tem facilitado a disseminação das informações sobre as condições de demanda entre os mercados; b) muitos paises liberalizaram seus subsetores cotonícolas ao passo que em outros, o papel do governo foi substancialmente alterado.

Para realizar a análise, foram construídas duas amostras: uma considerando o período 1985 a 1987 e outra referente ao periodo 1995 a 1997. Foram utilizados preços dos Estados Unidos, Grécia, Ásia Central, países francófonos da África e o Cotlook A Index como medida do preço no mercado mundial de algodão.

Os autores concluíram que as relações de preços entre a Ásia Central e os países francófonos da África foram as mais elevadas nos dois periodos, enquanto as relações entre os Estados Unidos e os outros mercados foram inexistentes no primeiro periodo. De acordo com o critério de qualidade de ajustamento $\left(\mathrm{R}^{2}\right)$, em quase todos os casos, houve melhoria nas relações de preço.

A principal fonte da melhoria nas relações de preço parece ser resultado da transmissão de preço no curto prazo e, numa extensão limitada, dos movimentos de longo prazo. Na medida em que a transmissão de preço no curto prazo reflete as condições de demanda e a convergência no longo prazo as condições de oferta, os resultados do estudo sugerem que, ao longo da última década, as informações sobre 
variação na demanda tem-se refletido muito mais rapidamente no presente, do que há uma década atrás (Baffes \& Ajwad, 1998).

No longo prazo, foi identificada convergência entre os preços na Ásia Centra e nos países francófonos da África e inexistência de convergência entre os preços nos Estados Unidos e nas outras três origens. O algodão produzido na Ásia Central e nos paises francófonos da África é quase todo destinado à exportação, o que torna ambos os mercados sujeitos às mesmas condições de demanda. No caso dos Estados Unidos, apenas $40 \%$ da produçāo é exportada, fazendo com que os preços estejam sujeitos às condições dos mercados doméstico e internacional.

Baffes \& Ajwad (1998, p.15) salientam a importância desses resultados para a administração do risco de preço:

"escassos co-movimentos entre os preços do algodão americano $e$ os demais implicam na necessidade de um contrato futuro, outro que não aquele da NYCE, que é o único negociado atualmente, exceto o contrato de São Paulo na Bolsa de Mercadorias \& Futuros, introduzido em 1996, mas com uma liquidez extremamente baixa". 


\section{CONSIDERAÇÕES TEÓRICAS ${ }^{18}$}

De acordo com a teoria do portfólio, o hedger tenta minimizar o risco de suas posições à vista e futura, considerando o retorno esperado. A referida teoria aborda a seleção e combinação de investimentos individuais, de tal forma que, quando tomados em conjunto, eles minimizam o risco total, de acordo com o retorno esperado. Analogamente, o mesmo conjunto de investimentos maximiza o retorno, para o nível de risco total estabelecido (Leuthold, Junkus \& Cordier, 1989). Surge, então, o conceito de razão de hedge de variância mínima, que é aquela que minimiza o risco total das posições à vista e futura, conforme o retorno esperado. Em termos práticos, é a proporção da posição à vista que deve ser assumida em posições opostas em mercados futuros, a fim de minimizar o risco do retorno esperado.

A equação (1) representa o retorno de um agente, na data da liquidação de sua posição futura $\left(\pi_{t}\right)$ :

$$
\pi_{t}=p_{t} q_{t-1}-c\left(q_{t-1}\right)-\left(f_{t}-f_{t-1}\right) b_{t-1}
$$

onde $p_{t}$ é o preço à vista no momento $t, q_{t-1}$ é a posição à vista, cuja decisão foi tomada em $t-1, c$ é uma função de custo (crescente e convexa), $f_{t}$ e $f_{t-1}$ são os preços futuros nos momentos $t$ e $t-1$,

18 Esta seção baseia-se em Myers \& Thompson (1989). 
respectivamente e $b_{t-1}$ é a venda de contratos futuros (compra se for negativo) no momento $t-1$.

$\mathrm{O}$ agente escolhe $q_{t-1}$ e $b_{t-1}$, de forma a maximizar uma função linear de média e variância do retorno, condicional às informações disponiveis em $t-1$ :

$$
\max E\left(\pi_{t} \mid X_{t-1}\right)-\frac{\lambda}{2} \operatorname{var}\left(\pi_{t} \mid X_{t-1}\right)
$$

onde $X_{t-1}$ é o conjunto de informaçōes disponíveis em $t-1$ e $\lambda$ é uma medida da aversão ao risco do agente. As condições de primeira ordem para maximização dessa função são:

$$
\begin{aligned}
& E\left(p_{t} \mid X_{t-1}\right)-c^{\prime}\left(q_{t-1}\right)-\lambda\left(\sigma_{p}^{2} q_{t-1}-\sigma_{p f} b_{t-1}\right)=0 \\
& E\left(f_{t} \mid X_{t-1}\right)-f_{t-1}+\lambda\left(\sigma_{f}^{2} b_{t-1}-\sigma_{p f} q_{t-1}\right)=0
\end{aligned}
$$

onde $\sigma_{p}^{2}=\operatorname{var}\left(p_{t} \mid X_{t-1}\right)$ é a variância condicional do preço à vista, $\sigma_{f}^{2}=\operatorname{var}\left(f_{t} \mid X_{t-1}\right)$ é a variância condicional do preço futuro e $\sigma_{p f}=\operatorname{cov}\left(p_{t}, f_{t} \mid X_{t-1}\right)$ é a covariância condicional entre os preços à vista e futuro. Todos os momentos são condicionais às informações disponiveis no momento $t-1$. Para derivar a regra do hedge ótimo, a partir do hedge de variância mínima, pressupõe-se que o agente é infinitamente averso ao risco $(\lambda \rightarrow \infty)$ ou o mercado futuro é eficiente ${ }^{19}$ [equação (4)]:

19 Um mercado futuro é eficiente quando uma nova informação é incorporada imediatamente ao preço do contrato, de forma que os preços futuros no momento $t$ contêm todas as informações disponiveis até aquele momento. Os agentes revêem suas 


$$
E\left(f_{t} \mid X_{t-1}\right)=f_{t-1}
$$

Utilizando-se a suposição dada pela equação (4) em (3"), obtém-se a regra do hedge ótimo, representada pela equação (5):

$$
r=\frac{\sigma_{p f}}{\sigma_{f}^{2}}=\frac{b_{t-1}}{q_{t-1}}
$$

Contudo, caso não se verifique a condição (4), a equação (5) ainda continua sendo a regra de variância minima, mas o hedge não é ótimo em termos de maximizar a função de média e variância do retorno (Heifner, 1972).

A razão ótima de hedge, descrita pela equação (5), pode ser estimada através de uma regressão de Mínimos Quadrados Ordinários do preço à vista contra o preço futuro no tempo, sendo igual ao coeficiente angular do modelo. Ederington (1979) foi um dos primeiros pesquisadores a derivar esse resultado, utilizando os preços à vista e futuro para estimar a regressão. O referido autor demonstra ainda que, através dessa regressão, pode-se obter uma medida da efetividade do hedge (hedging effectiveness).

Uma vez que o objetivo do hedger nesse modelo é reduzir o risco tanto quanto possivel, a efetividade do hedge é definida como a fração do risco, medida pela variância do portfólio, que é eliminada pelo hedging. Assim, a máxima redução na variância pode ser calculada através da equação (6):

posições e reformulam suas expectativas sempre que novas informações chegam ao mercado. Esse comportamento leva o preço a variar de forma aleatória, ou seja, as variações de preço do contrato no momento $t$ não estão relacionadas às variações de preço nos momentos anteriores. 


$$
E H=1-\frac{\sigma_{h}^{2^{*}}}{\sigma_{u}^{2}}
$$

onde $E H$ é a medida da efetividade do hedge, $\sigma_{h}^{2^{*}}$ é a variância de um portfólio que inclui posições futuras (hedged portfolio), num montante que minimiza a variância do retorno [razão ótima de hedge dada pela equação (5)] e $\sigma_{u}^{2}$ é a variância de um portfólio não hedgeado (unhedged portfolio). Assim, a equação (6) mostra que a efetividade do hedge é igual à redução percentual do risco de preço, devido à tomada de posições futuras na proporção da razão ótima de hedge.

Ederington (1979) mostra que, numa regressão simples dos preços à vista contra os preços futuros, ambos em nível, o valor do coeficiente de determinação da regressão $\left(\mathrm{R}^{2}\right)$, que é igual ao coeficiente de correlação entre os preços à vista e futuro ao quadrado, corresponde à efetividade do hedge, conforme a equação (7):

$$
R^{2}=\operatorname{Corr}_{p f}^{2}=1-\frac{\sigma_{h}^{2^{*}}}{\sigma_{u}^{2}}
$$

onde $\operatorname{Corr}_{p f}^{2}$ é coeficiente de correlação entre os preços à vista e futuro elevado ao quadrado.

A medida da efetividade do hedge pode ser utilizada para comparar diferentes contratos em diferentes Bolsas de futuros. Quanto maior for o $\mathrm{R}^{2}$ da regressão estimada para obter a razão ótima de hedge, maior será a efetividade do hedge e mais eficaz o instrumento de administração do risco de preço para determinado produto (Marshall, 1989). 
O problema com a estimativa da razão ótima de hedge utilizandose os preços à vista e futuro em nivel é que, geralmente, as séries econômicas exibem autocorrelação serial e a regressão estimada pode ser de origem espúria, isto é, indicar relação entre essas variáveis, quando na verdade o que existem são tendências correlacionadas no tempo.

Assim, visando corrigir esse problema, a especificação e a técnica de estimação da regressão de MQO para obtenção da razão ótima de hedge tem diferido de estudo para estudo. Alguns autores têm estimado uma regressão simples do retorno do preço à vista contra o retorno do preço futuro, sendo esses definidos como uma proporção da variação do preço, de um periodo para outro (Brown, 1985). Porém, o procedimento mais comum é fazer a regressão das variações dos preços à vista contra as variações dos preços futuros, com correções para autocorrelação (Gepert, 1995).

No primeiro caso, o $\mathrm{R}^{2}$ da regressão para obtenção da razão ótima de hedge não corresponde à efetividade do hedge, pois este será o quadrado da correlação entre os retornos dos preços à vista e futuro. No segundo caso, Marshall (1989) afirma que, redefinindo a regressão para utilizar os preços à vista contra os futuros, ambos na primeira diferença, a efetividade do hedge $\left(\mathrm{R}^{2}\right)$ passa a ser o quadrado do coeficiente de correlação entre as variações no preço à vista e as variações no preço futuro. O autor afirma que essa redefinição da efetividade do hedge tem um apelo intuitivo, porque o risco de preço origina-se da variação do mesmo e a efetividade do hedge depende de quanto da variação do preço à vista é compensada pela variação do preço futuro.

Existem controvérsias na literatura quanto à utilização de cada um desses valores para estimar a regressão que resultará na razão ótima de hedge. Em todos os casos, o coeficiente angular da regressão 
simples fornece a razão da covariância não-condicional entre a variável dependente e a explicativa e a variância não-condicional da variável explicativa. Entretanto, a variância e a covariância na derivação da regra do hedge ótimo são momentos condicionais, que dependem das informações disponiveis no momento da tomada de decisão de realizar o hedge.

Por essa razão, propõe-se o método desenvolvido por Myers \& Thompson (1989), o qual leva em consideração as informações disponiveis no momento $t-1$, para estimar a razão ótima de hedge para os contratos futuros de algodão em pluma da BM\&F e da NYCE.

Uma vez que o método proposto por Myers \& Thompson (1989) envolve a estimativa de uma regressão múltipla, o conceito de efetividade do hedge não se aplica ao coeficiente de determinação da regressão $\left(\mathrm{R}^{2}\right)$. Numa regressão múltipla, $\mathrm{o} \mathrm{R}^{2}$ não corresponde ao quadrado do coeficiente de correlação entre os preços à vista e futuro.

Por essa razão, após a estimava das razões ótimas de hedge, a equação (6) será utilizada para computar a efetividade do hedge na BM\&F e na NYCE, através do cálculo das variâncias dos portfólios hedgeado e não hedgeado. Dessa forma, poder-se-á comparar os contratos futuros dessas Bolsas como instrumentos de administração de risco de preço para o algodão em pluma brasileiro. 


\section{MÉTODOS}

\subsection{Estimação da razāo ótima de hedge $e^{20}$}

Myers \& Thompson (1989) propõem um enfoque de estimação generalizada da razão ótima de hedge. Esse método de estimação pressupõe que, no equilíbrio, os preços à vista e futuro comportam-se de acordo com os seguintes modelos:

$$
\begin{aligned}
& p_{t}=X_{t-1} \alpha+u_{t} \\
& f_{t}=X_{t-1} \beta+v_{t}
\end{aligned}
$$

nos quais $p_{t}$ é o preço à vista no momento $t, X_{t-1}$ é uma matriz que contém as informações condicionais relevantes para a formação dos preços à vista e futuro, $\alpha$ e $\beta$ são vetores de parâmetros não conhecidos, $f_{t}$ é o preço futuro no momento $t$ e $u_{t}$ e $v_{t}$ são termos de erro com média zero e não correlacionados serialmente, que apresentam uma matriz de covariãncia contemporânea $\Omega$, de forma que a estimativa de $\delta$ na equação de regressão múltipla descrita a seguir por (10) é igual ao estimador da razão ótima de hedge apresentado em (5):

$$
p_{t}=\delta f_{t}+X_{t-1} \alpha+\varepsilon_{t}
$$

20 Esta seção baseia-se em Myers \& Thompson (1989). 
O enfoque generalizado proposto por Myers \& Thompson (1989) consiste em estimar a razão ótima de hedge $(\delta)$ na equação (10), pelo método de Minimos Quadrados Ordinários (MQO). É importante observar que a estimação da equação (10) por MQO é simplesmente um mecanismo para computar diretamente a estimativa geral da razão ótima de hedge, não havendo uma interpretação estrutural dos coeficientes da regressão e considerando-se irrelevantes os problemas que surgem da utilização do preço futuro como uma variável explicativa adicional do preço à vista.

O procedimento de estimar a regressão simples do preço à vista contra o preço futuro, ambos em nivel, assume que todos os parâmetros da matriz $\alpha$ são iguais a zero, exceto o termo constante. Entretanto, é prudente incluir as variáveis relevantes à estimação da razão ótima de hedge na matriz $X_{t-1}$. Talvez este seja o aspecto mais dificil dessa estimação: identificar as variáveis a serem incluídas na matriz $X_{t-1}$ e as defasagens apropriadas para as mesmas.

Uma simplificação é construir a matriz $X_{t-1}$ apenas com o termo constante e os preços à vista e futuro defasados, pressupondo que todas as informações relevantes para estimação da razão ótima de hedge estão refletidas nessas variáveis. Contudo, na derivação da regra do hedge ótimo, considera-se que os mercados futuros são eficientes e, portanto, essa restrição precisa ser imposta ao modelo. A inclusão dessa pressuposição faz com que os preços à vista e futuro no equilibrio sejam descritos pelas seguintes equações:

$$
\begin{aligned}
& p_{t}=X_{t-1} \alpha+u_{t} \\
& f_{t}=f_{t-1}+v_{t}
\end{aligned}
$$


sendo $f_{t-1}$ o preço futuro no momento $t-1, u_{t}$ e $v_{t}$ os componentes aleatórios dos processos que descrevem o comportamento dos preços à vista e futuro, respectivamente, os quais estão contemporaneamente correlacionados.

Nesse caso, o método de MQO não é apropriado para a estimativa geral da razão ótima de hedge, porque as duas equaçōes apresentam variâveis explicativas diferentes. Sob essas circunstâncias, poder-se-ia utilizar o método das Equaçōes Aparentemente não-Correlacionadas (Seemingly Unrelated Regression - SUR) e suas estimativas das matrizes de variâncias e covariâncias para computar a razão ótima de hedge.

Todavia, a estimação da razão ótima de hedge através das equaçōes (11) e (12) pelo método SUR, e depois utilizando-se a equação (4), é equivalente a estimar $\delta$ pelo método de MQO na equação (13) (Myers \& Thompson, 1989):

$$
p_{t}=\delta \Delta f_{t}+X_{t-1} \alpha+\varepsilon_{t}
$$

sendo:

$p_{t}=$ preço à vista no momento $t$;

$\delta=$ razão ótima de hedge;

$\Delta f_{t}=$ diferença entre o preço futuro nos momento $t$ e $t-1$;

$X_{t-1}=$ matriz que inclui o termo constante e os preços à vista defasados;

$\varepsilon_{\mathrm{t}}=$ ruido branco.

Dessa forma, a estimativa geral da razão ótima de hedge através da equação (13), utilizando-se o método de MQO é compativel com a restrição de mercado futuro eficiente. 
Até o momento, assumiu-se, para desenvolver a equação (13), que os modelos de equilíbrio (11) e (12) são conhecidos. Porém, esse não é o caso na prática. A especificação desses modelos é um ponto importante na estimação da razão ótima de hedge.

Para fins do presente estudo, apenas as variáveis defasadas do preço à vista serão incluídas na matriz $X_{t-1}$, de forma que pressupõe-se, a priori, que essa variável é descrita por um processo autorregressivo (AR) e todas as demais variáveis explicativas do modelo estão refletidas no preço à vista defasado. Assim, faz-se necessário especificar a ordem do AR que descreve o preço à vista, ou seja, o número de defasagens dessa variável a ser incluído na matriz $X_{t-1}$, da equação (13).

Quanto ao mercado futuro, é necessário verificar se o mesmo é eficiente, isto é, se a série de preços futuros a ser utilizada no presente estudo comporta-se segundo um processo autorregressivo de ordem um, sem os termos constante e tendência deterministica, conforme a equação descrita em (12). Caso os mercados futuros não sejam eficientes, a estimação da razão ótima de hedge é inconsistente, porque a eficiência do mercado futuro é uma condição para a derivação da regra do hedge ótimo.

Entre os critérios mais utilizados para determinação da ordem de processos autorregressivos estão o Akaike Information Criterion (AIC) e o Schwarz Criterion (SC), os quais serão utilizados no presente estudo. Tais critérios são representados, respectivamente, pelas seguintes equações:

$$
\begin{aligned}
& A I C=\ln s^{2}+\left(\frac{2}{T}\right)\left(n^{o} \text { de parâmetros }\right) \\
& S C=\ln s^{2}+\left(\frac{\ln T}{T}\right)\left(n^{o} \text { de parâmetros }\right)
\end{aligned}
$$


sendo $s^{2}$ a soma de quadrados de resíduos da equação autorregressiva, nas defasagens sucessivas em relação à série original, representada pelas equações (11) e (12) e $T$ o número de observações utilizado para estimá-la. A ordem do processo autorregressivo é a que resultar no menor valor desses critérios, considerando-se uma seqüência de ajustamentos, na qual o número de defasagens do modelo aumenta sucessivamente.

Para estimar a equação (13), ainda é necessário verificar a estacionariedade das séries de preço à vista e futuro, a fim de se utilizar o método de MQO. Caso a série de preços à vista seja não estacionária, a equação (13) deve ser especificada com o preço à vista na primeira diferença, em vez dessa variável em nível. No caso dos preços futuros, a série deve ser estacionária na primeira diferença, para que a equação (13) possa ser estimada por MQO. Para verificar se os mercados futuros da BM\&F e da NYCE são eficientes serão realizados testes de raiz unitária nas séries de preços futuros, conforme proposto por Saboya \& Bacchi (1999).

É importante salientar que o enfoque utilizado no presente estudo para estimar a razão ótima de hedge pressupõe que os custos envolvidos no hedging (taxa de corretagem e demais custos referentes à operação), bem como o custo de oportunidade de manter uma conta de margem são nulos. Além disso, não são considerados os custos de obtenção das informações nos mercados à vista e futuro. 


\subsection{Testes de raiz unitária}

Os testes de raiz unitária são utilizados para verificar se uma série temporal é estacionária em nivel ou torna-se estacionária nas diferenças, isto é, se ela se desenvolve aleatoriamente no tempo, ao redor de uma média constante e com variância finita (a qual não varia ao longo do tempo), refletindo alguma forma de equilíbrio estável. No contexto de análise de regressão, pressupõe-se que as séries de dados são estacionárias.

A utilização de séries não estacionárias, isto é, que apresentam tendência estocástica, pode levar a regressões espúrias, que implicam em relações entre as variáveis, quando o que está presente, na verdade, são tendências correlacionadas no tempo (Harris, 1995). Numa regressão espúria, as estatísticas $t$ são geralmente significativas, porém os resultados não têm significado econômico.

Se uma seqüência apresenta tendência estocástica, qualquer erro no período t nunca decairá, de forma que o desvio do modelo será permanente e a variância do erro aumentará infinitamente ao longo do tempo. Por essa razão, as estimativas de Mínimos Quadrados não são consistentes e as inferências estatísticas a partir dos testes usuais não se aplicam, embora os coeficientes estimados na regressão apresentemse freqüentemente significativos (Enders, 1995).

Phillips ${ }^{21}$, citado por Enders (1995), afirma que esse problema não desaparece à medida que o tamanho da amostra aumenta. Na verdade, o autor afirma que quanto maior o tamanho da amostra, maior a probabilidade de se concluir erroneamente que o coeficiente estimado é estatisticamente diferente de zero. Em geral, as séries não estacionárias

21 PHILLIPS, P. Understanding spurious regressions in econometrics. Journal of Econometrics, v.33, p. 311-20, 1986. 
podem tornar-se estacionárias tomando-se diferença(s) em relação à série original.

Existem diversos testes para verificar a existência de raiz unitária em séries temporais. Segundo Harris (1995), os mais utilizados na literatura são os desenvolvidos por Dickey \& Fuller $(1979,1981)$ e por Phillips \& Perron (1988), baseado em Phillips (1987). No presente estudo, serão utilizados os testes de Dickey e Fuller (DF) e Dickey e Fuller Aumentado (DFA) para verificar a existência de raiz unitária nas séries utilizadas nas análises.

O teste de Dickey e Fuller (DF) para verificar a presença de raiz unitária numa série $Y_{t}$, consiste em estimar a equação (16) pelo método de Mínimos Quadrados Ordinários:

$$
\Delta Y_{t}=(\rho-1) Y_{t-1}+u_{t}
$$

sendo:

$\Delta Y_{t}=$ série $Y_{t}$ na primeira diferença;

$Y_{t-1}=$ série $Y_{t}$ defasada de um período;

$u_{t}=$ ruído branco.

$\begin{array}{ll}\text { e testar a hipótese: } & \mathrm{H}_{0}: \rho-1=0 \\ & \mathrm{H}_{\mathrm{a}}: \rho-1<0 \quad[\rho-1] \in(-2,0)\end{array}$

utilizando-se o valor de $t$ relativo à essa hipótese e comparando-o com o valor crítico dado pela distribuição de DF relativo à estatística $\tau$. A não rejeição da hipótese nula indica que o processo tem raiz unitária e portanto a série é não estacionária. Nesse caso, é necessário uma diferença para torná-la estacionária. 
O teste de DF envolve a pressuposição de que o processo gerador dos dados é autorregressivo de ordem um [AR(1)] e $u_{t}$ é uma série ruído branco. Assim, para realização do mesmo, é preciso determinar o processo gerador dos dados e especificar o modelo a ser testado quanto aos componentes deterministicos tendência e constante. Uma vez que não se conhece esse processo na prática, faz-se necessário partir de uma especificação mais geral, incluindo-se tais componentes no modelo de regressão usado para o teste, conforme o descrito em (16'):

$$
\Delta Y_{t}=\mu_{b}+\eta Y_{t-1}+\gamma_{c} T+u_{t}
$$

sendo:

$\mu_{b}=$ termo constante;

$\eta=(\rho-1)$

$T=$ tendência determinística.

Para cada modelo considerado quanto à presença dos termos constante e/ou tendência determinística, existe uma estatística correspondente para testar a presença de raiz unitária na série. O valor de $t$ calculado relativo à hipótese nula deve ser comparado com o valor crítico da estatística correspondente ao tipo de modelo especificado (quanto à inclusão dos componentes determinísticos), ao nível escolhido de probabilidade.

Adicionalmente, Dickey \& Fuller (1981) fornecem as estatisticas $\phi_{1}, \phi_{2}$ e $\phi_{3}$ para testar hipóteses conjuntas sobre a significância dos coeficientes dos componentes determinísticos do modelo e a presença de raiz unitária na série.

A seleção do modelo que mais se aproxima do processo gerador dos dados e os testes para presença de raiz unitária devem ser feitos de 
acordo com procedimentos seqüenciais. No presente estudo, será adotado aquele sugerido por Doldado, Jenkinson \& Sosvilla-Rivero22, modificado por Enders (1995), o qual é apresentado no Apêndice 1.

Conforme explicitado anteriormente, o teste de DF envolve a pressuposição de que o processo gerador dos dados é um $A R(1)$. Se um modelo AR(1) for usado quando, de fato, a variável $Y_{t}$ segue um processo autorregressivo de ordem $\mathrm{p}>1$ [AR(p)], os erros apresentarão autocorrelação para compensar a falha na especificação da estrutura dinâmica de $Y_{t}$ (Harris, 1995). A autocorrelação dos erros invalida o uso da distribuição DF.

Então, considerando-se uma série descrita por um processo autorregressivo de ordem $\mathrm{p}>1[\mathrm{AR}(\mathrm{p})]$, conforme apresentado em (18):

$$
Y_{t}=\rho_{1} Y_{t-1}+\ldots+\rho_{p} Y_{t-p}+u_{t}
$$

o teste apropriado para verificar a existência de raiz unitária é o de Dickey e Fuller Aumentado (DFA), o qual consiste em testar a hipótese (19):

$$
\begin{aligned}
& \mathrm{Ho}_{0}: \theta=0 \\
& \mathrm{H}_{\mathrm{a}}: \theta<0
\end{aligned}
$$

na equação (20) estimada por Minimos Quadrados Ordinários:

$$
\Delta Y_{t}=\mu_{b}+\theta Y_{t-1}+\sum_{i=1}^{p-1} \omega_{i} \Delta Y_{t-i}+\gamma_{c} T+u_{t}
$$

${ }^{22}$ DOLDADO, J.; JENKINSON, T.; SOSVILLA-RIVERO, S. Cointegration and unit roots, Journal of Economic Surveys, v.4, p. 249-73, 1990. 
sendo:

$$
\begin{aligned}
& \theta=\sum_{i=1}^{p} \rho_{i}-1 \\
& \omega_{i}=-\sum_{j=i+1}^{p} \rho_{j}
\end{aligned}
$$

Da mesma forma que no teste de DF, o valor de $t$ calculado relativo à hipótese nula deve ser comparado com o valor crítico da estatística correspondente ao tipo de modelo especificado (quanto à inclusão dos componentes determinísticos), ao nível escolhido de probabilidade. Se a hipótese nula não for rejeitada, o processo é não estacionário e deve-se repetir o teste descrito em (20), considerando-se uma diferença a mais, a fim de verificar se a série $Y_{t}$ é estacionária na primeira diferença. Se a hipótese nula não for rejeitada novamente, deve-se aumentar o número de diferenças até que o teste apresente-se significativo, ou seja, para cada raiz unitária, tem-se a necessidade de uma diferença a mais.

O teste de DFA também pressupõe resíduos não correlacionados, portanto, o valor de (p) deve ser tal que torne $u_{t}$ uma série ruído branco. Então, o teste de DFA é comparável ao DF, mas envolve a inclusão de um número não conhecido de defasagens da variável dependente na primeira diferença, para captar a autocorrelação das variáveis omitidas que, caso contrário, estariam refletidas no termo de erro (Harris, 1995).

Portanto, é importante a correta determinação do número de defasagens a ser incluído no modelo para fins do teste de DFA. Poucas defasagens podem levar a rejeitar a hipótese nula quando ela é verdadeira, enquanto a inclusão de muitas defasagens pode reduzir o poder do teste (Enders, 1995).

A ordem do processo $\mathrm{AR}(\mathrm{p})$ para fins dos testes de DF ou DFA pode ser determinada através de diversos critérios. No presente estudo, serão utilizados o Akaike Information Criterion (AIC) e o Schwarz 
Criterion (SC), representados, respectivamente, pelas equações (14) e (15) descritas na seção anterior.

\section{Limitações dos testes de raiz unitária}

Embora bastante utilizados, os testes para verificar a presença de raiz unitária apresentam algumas limitações, inerentes a qualquer método de análise em economia aplicada. Assim, é importante salientar alguns problemas na realização desses testes, os quais devem ser considerados oportunamente na análise dos resultados obtidos.

Formalmente, o poder de um teste é igual à um menos a probabilidade de cometer erro tipo II ${ }^{23}$, ou seja, o poder do teste é a probabilidade de rejeitar a hipótese nula, dado que ela é falsa. O poder dos testes de raiz unitária é muito baixo; esses testes não conseguem distinguir entre processos com raiz unitária e aqueles contendo uma raiz cujo valor é próximo da unidade. Por essa razão, esses testes freqüentemente indicam que a série contém uma raiz unitária.

Além disso, os testes de raiz unitária têm baixo poder de distinguir entre processos com tendência estocástica (difference stationary) e deterministica (trend stationary). Em amostras finitas, qualquer processo com tendência determinística pode ser bem aproximado arbitrariamente por um processo contendo raiz unitária e vice-versa, especialmente quando o tamanho da amostra é pequeno.

Outro problema refere-se à escolha do número de defasagens da variável na primeira diferença, a ser incluído no modelo para testar a presença de raiz unitária na série. Diferentes critérios podem levar à determinação de defasagens distintas, as quais, em geral, produzem diferentes resultados com relação à rejeição da hipótese nula de não

${ }^{23} \mathrm{O}$ erro tipo II é a probabilidade de não rejeitar $\mathrm{H}_{0}$ dado que $\mathrm{H}_{\mathrm{O}}$ é falsa. 
estacionariedade. Por essa razão, é fundamental especificar corretamente o número de defasagens a ser incluído no modelo para fins dos testes.

\section{Os dados utilizados na estimação da razão ótima de hedge}

Os preços à vista utilizados no presente estudo para estimação da razão ótima de hedge são representados pelas cotações diárias do Indicador de Preço do Algodão em Pluma na Cidade de São Paulo ESALQ/BM\&F (Indipluma) e foram obtidos no Centro de Pesquisa em Economia Aplicada/Fundação de Estudos Agrários "Luiz de Queiroz" (CEPEA/FEALQ).

Os preços futuros para estimar a razão ótima do cross hedge foram obtidos junto à New York Cotton Exchange (NYCE) e à Companhia Nacional de Abastecimento (CONAB) e referem-se à cotação diária dos preços do contrato futuro número 2 de algodão em pluma dessa Bolsa. Os preços futuros para estimar a razão ótima de hedge no Brasil foram obtidos junto à Bolsa de Mercadorias \& Futuros (BM\&F) e referem-se às cotações diárias dos preços do contrato futuro cambial de algodão em pluma. Ambas as séries de preços referem-se às cotações do primeiro vencimento do contrato futuro, de forma que ao vencer um contrato, os preços futuros referem-se ao próximo mês de vencimento. Todos os valores estão em centavos de dólar por libra peso.

O período considerado na estimativa da razão ótima de hedge para os contratos da NYCE e da BM\&F foi 02 de janeiro de 1997 a dezembro de 1999. A série tem início em 1997, devido ao relançamento do contrato futuro de algodão em pluma pela BM\&F em novembro de 1996. O término da série é no mês de dezembro de 1999, entretanto, os contratos futuros da BM\&F e da NYCE a presentam datas de vencimento distintas. Por essa razão, a série de preços futuros da $B M \& F$ termina no 
dia 15 de dezembro de 1999, enquanto a série de preços futuros da NYCE termina no dia 07 de dezembro de 1999.

As séries de preços à vista e futuro referem-se às cotações diárias. Entretanto, a razão ótima de hedge foi calculada utilizando-se as médias semanais desses preços, devido a problemas de autocorrelação serial. As médias semanais foram calculadas como a média aritmética dos preços em cada semana, utilizando-se o número de observações disponivel em cada uma delas. Todos os valores foram transformados em logaritmos para estabilizar a variância das séries.

Nas semanas em que houve vencimento de contrato e parte das observações referiam-se a um vencimento e parte a outro, foram calculadas duas médias semanais, uma relativa a cada contrato. Nesse caso, quando apenas o dia do vencimento caía em uma nova semana e as demais observações referiam-se a outro contrato, a média semanal do contrato que estava vencendo foi representada pela observação da data do vencimento e a média semanal do contrato que passava a ser o primeiro futuro foi calculada com as demais observações da semana. As Figuras 13 e 14 mostram a evolução das médias semanais dos preços à vista (Indipluma ESALQ/BM\&F) e futuros utilizados nas estimações. 
Figura 13. Médias semanais do Indipluma ESALQ/BM\&F e dos preços futuros do algodão em pluma na BM\&F - Jan./1997 a Dez./ 1999.

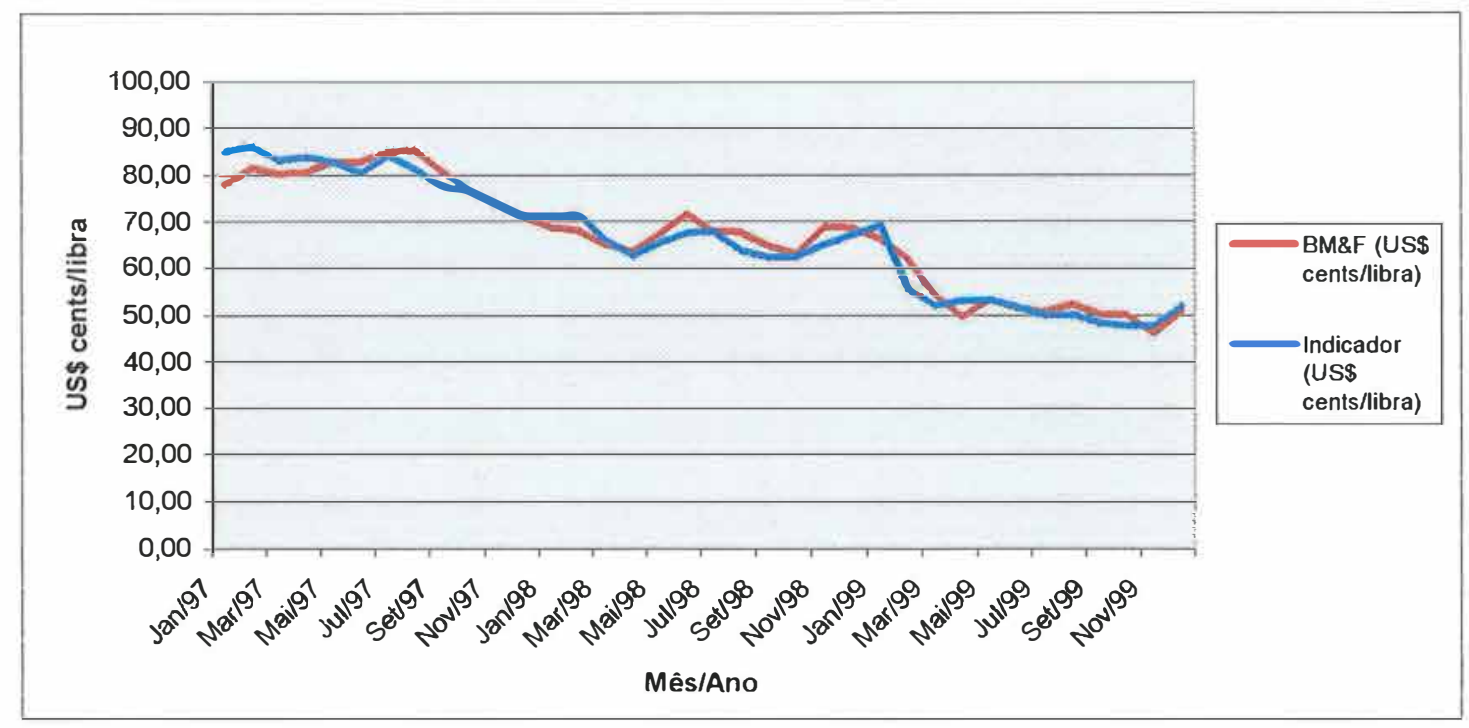

Fonte: CEPEA ${ }^{24}$; BM\&F(2000b).

Figura 14. Médias semanais do Indipluma ESALQ/BM\&F e dos preços futuros do algodão em pluma na NYCE - Jan./1997 a Dez./1999.

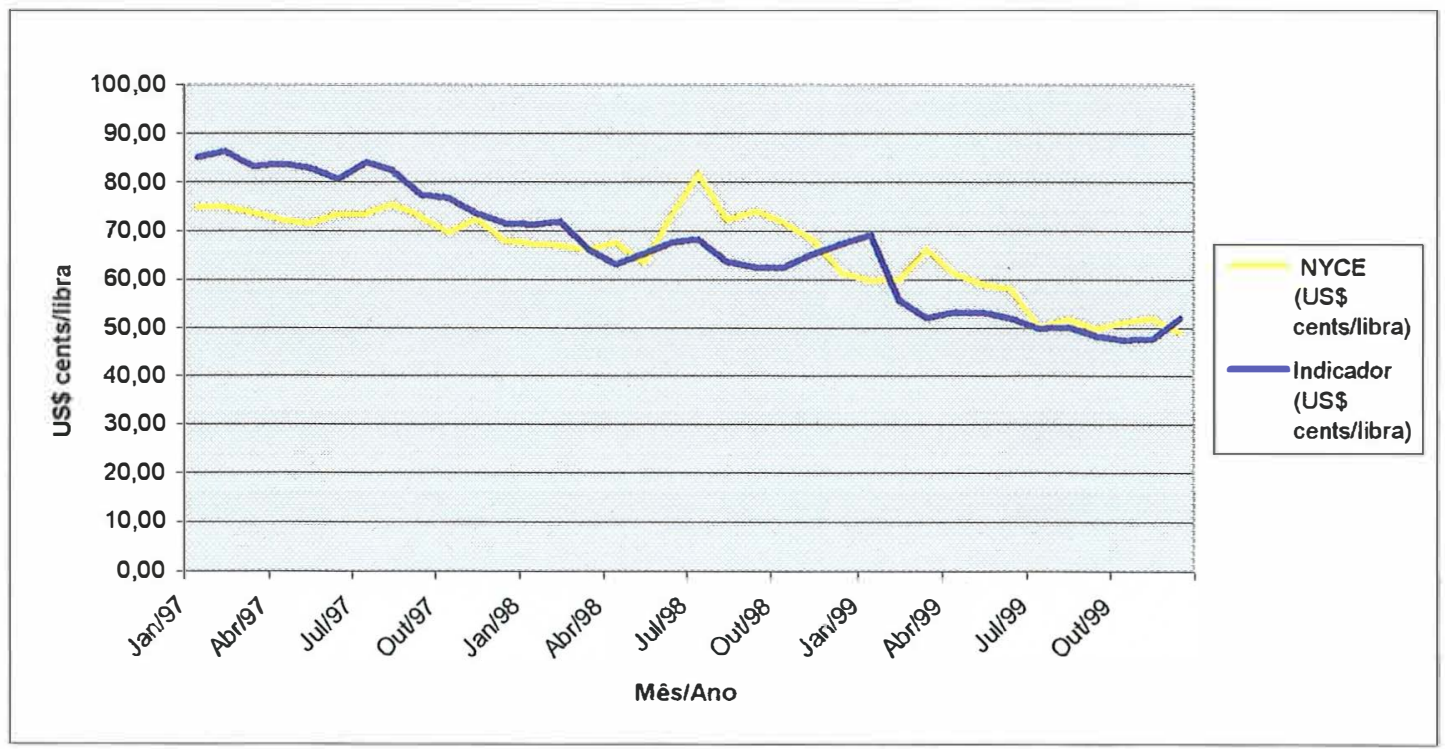

Fonte: CEPEA24; Doyle, M. (1999a, 1999b); CONAB25.

${ }^{24}$ CEPEA. Comunicação pessoal, 1999 e 2000.

${ }^{25}$ CONAB. Correspondência pessoal, 2000. 


\subsection{Análise da relação entre as importaçōes financiadas de algodão em pluma e a arbitragem das taxa de juros nos mercados interno e externo}

Inicialmente, para analisar a evolução das importações financiadas, a fim de verificar se as mesmas estão vinculadas à arbitragem das taxas de juros internas e externas, será calculado o ganho financeiro advindo da internalização de um financiamento externo para importaçāo de algodão em pluma. Esse ganho financeiro é igual ao diferencial entre as referidas taxas de juros e será calculado conforme o estudo de Rezende et al. (1997).

Posteriormente, serão realizados testes de raiz unitária e análises de regressāo entre o valor das importações financiadas de algodão em pluma e o ganho financeiro associado a essas operações, para verificar se existe uma relação entre essas variáveis.

Através da análise conjunta da evolução do diferencial das taxas de juros interna e externa e das importações financiadas de algodão em pluma, pode-se obter indicações à respeito da vinculação da importação dessa fibra com o financiamento do capital de giro das empresas importadoras.

No estudo de Rezende et al. (1997), os autores analisaram a evolução das operações de importações financiadas no período de 1991 a 1996, procurando estabelecer os vinculos com a arbitragem das taxas de juros interna e externa. Foi calculado o ganho financeiro associado à internalização de um financiamento externo, através da diferença entre as taxas de juros interna e externa.

No presente estudo, serão consideradas apenas as importações financiadas de algodão em pluma. Assim, o ganho fïnanceiro advindo da in ternalização de um financiamento externo para importação de algodão 
em pluma será a diferença entre a taxa de juros interna e a taxa de juros praticada nas importaçōes financiadas dessa fibra. $O$ procedimento para calcular essa diferença é descrito a seguir e segue o estudo de Rezende et al. (1997).

O diferencial entre as taxas de juros nos mercados interno e externo será calculado de duas formas: numa, a taxa de juros no mercado interno será representada pela taxa efetiva de retorno de uma aplicação em real descontada a variação cambial ${ }^{26}$ e em outra, pela taxa real de juros no mercado interno.

Utilizando-se a defïnição convencional, a taxa efetiva de retorno de uma aplicação em real descontada a variação cambial é dada pela equação (21):

$$
r_{u s}=\frac{1+i_{n}}{1+\dot{e}}-1
$$

sendo:

$r_{u s}=$ taxa de retorno da aplicação em real descontada a variação cambial ("prêmio ou cupom cambial");

$i_{n}=$ taxa de juros nominal no mercado interno;

$\dot{e}=$ taxa de variação cambial.

Então, o diferencial $d_{1}$ entre a taxa de retorno de uma aplicação em real descontada a variação cambial $\left(r_{u s}\right)$ e a taxa de juros praticada nas importaçōes financiadas de algodão em pluma $\left(i_{e}\right)$, ambas em dólar, é dada pela equação (22):

$$
d_{1}=r_{u s}-i_{e}
$$

26 Refere-se à variação da taxa de câmbio R\$/US\$. 
A taxa real de juros no mercado interno $\left(i_{r}\right)$ é dada pela equação (23), segundo a forma convencional:

$$
i_{r}=\frac{1+i_{n}}{1+\dot{p}}-1
$$

sendo:

$i_{r}=$ taxa real de juros no mercado interno;

$i_{n}=$ taxa de juros nominal no mercado interno;

$\dot{p}=$ inflação.

Assim, o diferencial $d_{2}$ entre a taxa real de juros no mercado interno $\left(i_{r}\right)$ e a taxa de juros praticada nas importações financiadas de algodão em pluma $\left(i_{e}\right)$ é dada pela equação (24):

$$
d_{2}=i_{r}-i_{e}
$$

Os diferenciais $d_{1}$ e $d_{2}$ representam o ganho financeiro advindo da internalização de um financiamento externo para importação de algodão em pluma e correspondem ao retorno de uma operação de arbitragem entre as taxas de juros interna e externa.

Os dados utilizados para a análise da relação entre as importaçōes financiadas de algodão em pluma e a arbitragem das taxas de juros interna e externa

O periodo de análise da relação entre as importações financiadas de algodão em pluma e o diferencial da taxa de juros nos mercados 
interno e externo compreende de janeiro de 1996 a dezembro de 1999, utilizando-se dados mensais. As taxas de captação de recursos externos informadas pelo Banco Central estão disponiveis trimestralmente no periodo 1993 a 1995. A partir de 1996, esses dados estão disponiveis mensalmente. Por essa razão, a análise será restrita ao periodo janeiro de 1996 a dezembro de 1999, com um total de 48 observações.

A taxa de juros nominal no mercado interno é representada pela taxa do CDB e pelo custo efetivo do financiamento de capital de giro, ambas pré fixadas ${ }^{27}$, divulgadas na revista Juros \& Moedas (v.2-8, 1994 - 2000). No primeiro caso, a taxa é relevante para um aplicador de recursos, enquanto que no segundo, a mesma corresponde ao custo de captação para um tomador de empréstimos. Ambas referem-se à taxa mais freqüente negociada no mercado financeiro na quarta-feira de cada semana. Os dados utilizados na análise foram obtidos a partir do cálculo da média mensal desses valores. Assim, os diferenciais $d_{1}$ e $d_{2}$ serão calculados levando-se em conta o conceito do aplicador e do tomador de recursos.

A taxa real de juros no mercado interno é representada pela taxa líquida real ao ano do CDB pré-fixado e pelo custo efetivo real ao ano do financiamento do capital de giro pré-fixado, publicados na revista Juros \& Moedas (v.2-8, 1994 - 2000). A primeira corresponde à diferença percentual entre a taxa líquida nominal do CDB pré-fixado e a variação da inflação e o segundo é a diferença percentual entre o custo efetivo nominal do financiamento do capital de giro e a variação da inflação. Esta última é representada em ambos os casos pelo Índice de Geral de

27 No caso do CDB pré-fixado, a taxa líquida corresponde à taxa bruta depois de deduzido o imposto de renda (IR) e no caso do financiamento do capital de giro, o custo efetivo nominal corresponde à taxa nominal, acrescida do imposto sobre operações financeiras (IOF). 
Preços de Mercado (IGP-M), calculado pela Fundaçāo Getúlio Vargas (FGV).

$\mathrm{Na}$ equação (21), a variação cambial refere-se à variação percentual nos últimos 12 meses da taxa de venda do dólar comercial, divulgada pelo Banco Central, publicada na revista Juros \& Moedas (v.2-8, 1994 - 2000).

Não foi possivel obter as taxas de juros praticadas nas importações financiadas de algodão em pluma para calcular os diferenciais $d_{1}$ e $d_{2}$. Dessa forma, as mesmas serão representadas pelos custos de captação de recursos externos, obtidos junto ao Banco Central do Brasil (2000). Esse custo é a média ponderada da taxa paga nas operações de captação autorizadas por aquela autoridade monetária, mediante lançamento de títulos nos mercados internacionais, nas modalidades Floating Rate Notes, Fixed Rate Notes, Floating Rates Certificates of Deposit, Fixed Rates Certificates of Deposit e bônus de colocação pública ou privada.

As importações de algodāo em pluma para o período 1996 a 1999 foram obtidas junto à Secretaria da Receita Federal - Coordenaçāo de Estatísticas Econômico - Tributárias/Divisão de Estatísticas do Comércio Exterior (COEST/DIVEX) e referem-se ao tipo de cobertura cambial: com prazo de pagamento até 180 dias, entre 180 e 360 dias e acima de 360 dias.

\subsection{Análise de co-integração28 entre os preços do algodão em pluma nos mercados interno e externo}

No presente estudo, será utilizado o enfoque de Engle \& Granger (1987) para identificar a existência de co-integração entre as séries de

${ }^{28}$ Esta seção baseia-se em Harris, 1995. 
preços do algodão em pluma nos mercados doméstico e internacional, a fim de verificar se os mesmos constituem mercados integrados. Tal enfoque é descrito a seguir.

A interpretação econômica de co-integração é de que, se duas (ou mais) séries estão ligadas para formar uma relação de equilíbrio de longo prazo, então, mesmo que elas contenham tendências estocásticas (isto é, sejam não estacionárias), elas se moverão conjuntamente ao longo do tempo se a diferença entre elas for estável, isto é, estacionária. Então, o conceito de co-integração "imita" a existência de um equilíbrio de longo prazo, para o qual um sistema econômico converge ao longo do tempo (Harris, 1995).

Assim, a identificação da co-integração com uma relação de equilíbrio torna possivel a utilização de variáveis não estacionárias em análise de regressão. Se as variáveis forem co-integradas, as regressões podem fornecer importantes informações sobre as relações de longo prazo entre as mesmas, pois nesse caso as inferências estatísticas a partir dos testes $t$ e F são aplicáveis. Entretanto, se não for identificada a co-integração entre elas, retorna-se ao problema das regressões espúrias.

Se duas séries temporais $X_{t}$ e $Y_{t}$ são ambas $\mathrm{I}(\mathrm{d})$, isto é, integradas de ordem d, pode ocorrer que uma combinação linear dessas duas séries também seja I(d). Nesse caso, a série de resíduos da regressão de $Y_{t}$ contra $X_{t}$ seria I(d). Se, contudo, existir um vetor $\beta$, tal que o termo de perturbação da regressão $\left(\hat{\varepsilon}=Y_{t}-\hat{\beta} X_{t}\right)$ é de uma ordem de integração menor, $\mathrm{I}(\mathrm{d}-\mathrm{b})$, onde $\mathrm{b}>0$, então, $Y_{t}$ e $X_{t}$ são definidos por Engle \& Granger (1987) como co-integrados de ordem (d, b). Assim, se $Y_{t}$ e $X_{t}$ fossem ambas $\mathrm{I}(1)$ e $\varepsilon_{t} \sim \mathrm{I}(0)$, as duas séries seriam co-integradas de ordem CI $(1,1)$. O termo $\varepsilon_{t}$ pode ser interpretado como um 
desequilíbrio, isto é, a distância que o sistema está do equilíbrio de longo prazo no momento t.

Engle \& Granger (1987) sugerem um procedimento em duas etapas para testar co-integração entre variáveis. A primeira envolve a estimação da relação de longo prazo por Minimos Quadrados Ordinários (MQO) e a realização de testes de raiz unitária nos resíduos dessa regressão. A segunda etapa compreende a estimação do Modelo de Correção de Erro (MCE), que é a representação da dinâmica de curto prazo de variáveis co-integradas.

Considerando-se a primeira etapa do processo, o primeiro passo para proceder os testes de co-integração sob o enfoque de Engle \& Granger (1987) é verificar a ordem de integração das variáveis. Por definição, para serem co-integradas, é necessário que elas tenham a mesma ordem de integração ${ }^{29}$. Serão utilizados os testes de Dickey e Fuller e de Dickey e Fuller Aumentado para testar a presença de raiz unitária nas séries.

O segundo passo é estimar a relação de equilíbrio de longo prazo entre as variáveis $Y_{t}$ e $X_{t}$, que consiste em estimar a equação (25) pelo método de Mínimos Quadrados Ordinários (MQO):

$$
Y_{t}=\beta_{0}+\beta_{1} X_{t}+\varepsilon_{t}
$$

Caso as variáveis sejam co-integradas, obtém-se estimadores "superconsistentes" dos parâmetros de co-integração $\beta_{0}$ e $\beta_{1}$. De acordo com Stock ${ }^{30}$ citado em Harris (1995), segundo a propriedade de

\footnotetext{
29 Se ambas as variáveis forem estacionárias, não é necessário prosseguir, pois os métodos de estimação padrão aplicam-se às variáveis estacionárias. Se as variáveis forem integradas de ordens diferentes, é possivel concluir que elas são não cointegradas.

30 STOCK, J.H. Asymptotic properties of least-squares estimators of cointegrating vectors. Econometrica, v. 55, p.1035-56, 1987.
} 
"superconsistência", se $Y_{t}$ e $X_{t}$ são ambas variáveis não estacionárias I(1) e $\varepsilon_{t} \sim \mathrm{I}(0)$, conforme aumenta o tamanho da amostra, os estimadores de MQO convergem para seu valor verdadeiro à uma taxa muito mais rápida do que no caso de variáveis estacionárias $\mathrm{I}(0)$.

Para testar a hipótese nula de que $Y_{t}$ e $X_{t}$ são não co-integradas na estrutura de Engle \& Granger (1987), testa-se diretamente a hipótese nula $\varepsilon_{t} \sim \mathrm{I}(1)$ contra a hipótese alternativa $\varepsilon_{t} \sim \mathrm{I}(0)$. A rejeição da hipótese nula implica que a seqüência de resíduos é estacionária e dado que as variáveis $Y_{t}$ e $X_{t}$ são ambas $\mathrm{I}(1)$, é possivel concluir que as séries são co-integradas de ordem $(1,1)$. No presente estudo, os testes de Dickey e Fuller e o Dickey e Fuller Aumentado serão utilizados para testar a presença de raiz unitária na série de resíduos da relação de longo prazo entre as variáveis ${ }^{31}$.

A principal caracteristica de variáveis co-integradas é que seus caminhos no tempo são caracterizados por desvios em relação ao equilíbrio de longo prazo. A dinâmica de curto prazo dessas variáveis é influenciada por tais desvios, o que implica na relação entre cointegração e correção de erro. Engle \& Granger (1987) mostram que, se $Y_{t}$ e $X_{t}$ são $\mathrm{CI}(1,1)$, tem que existir um Modelo de Correção de Erro (MCE) e, reciprocamente, um MCE gera séries co-integradas.

Assim, a segunda etapa do processo para testar co-integração sob o enfoque de Engle \& Granger (1987) consiste em estimar o Modelo de Correção de Erro, o qual representa a dinâmica de curto prazo. Se as

31 Uma vez que os erros da relação de longo prazo são estimativas dos verdadeiros erros, o valor de $t$ para fins do teste não deve ser comparado com os valores críticos da distribuições de DF. Isso porque o método de Mínimos Quadrados Ordinários minimiza a soma de quadrados de residuos, de forma a obter-se a menor variância possivel dos residuos. Esse procedimento prejudica a obtenção de um processo estacionário dos erros na equação (25). Por essa razão, os valores fornecidos por Engle \& Granger (1987) e Engle \& Yoo (1992) (para mais de duas variáveis) devem ser utilizadas para fins do teste de raiz unitária nos residuos da relação de longo prazo entre as variáveis. 
variáveis são co-integradas, os resíduos da relação de equilíbrio de longo prazo podem ser usados para estimar o MCE, o qual deve, necessariamente, incluir uma variável (defasada de um periodo) que meça os desvios em relação ao equilibrio de longo prazo.

Portanto, se $Y_{t}$ e $X_{t}$ são $\mathrm{C}(1,1)$, seu respectivo MCE pode ser representado pela equação (26):

$$
\Delta Y_{t}=a_{0} \hat{\varepsilon}_{t-1}+\sum_{i=1} b_{i} \Delta X_{t-i}+\sum_{i=1} c_{i} \Delta Y_{t-i}+e_{t}
$$

sendo $\hat{\varepsilon}_{t-1}=Y_{t-1}-\beta_{0}-\beta_{1} X_{t-1}$ a estimativa do desvio da relação de equilíbrio de longo prazo no periodo (t-1), ou seja, é o termo de correção de erro.

A equação (26) pode ser estimada por MQO e posteriormente, deve-se verificar a adequação do modelo. Os resíduos não devem apresentar autocorrelação serial e o coeficiente estimado do termo de correção de erro (chamado coeficiente de velocidade de ajustamento) deve ser significativamente diferente de zero, se as variáveis são cointegradas.

A análise das relações de co-integração sob o enfoque de Engle \& Granger apresenta algumas limitações. A mesma não é indicada quando considera-se a possibilidade de existir mais de um vetor de cointegração ou quando existe endogeneidade do regressor [relação causal no sentido da variável dependente para a(s) explicativa(s)].

O enfoque de Engle \& Granger (1987) para identificar a existência de co-integração entre as séries de preços do algodão em pluma nos mercados doméstico e internacional será utilizado no presente estudo, assumindo-se algumas pressuposições. Considera-se, neste estudo, que 
o Brasil é um tomador de preços no mercado mundial de algodão em pluma.

Apesar de ser um grande importador como nação isolada, as importaçōes brasileiras estiveram em torno de $5 \%$ do total mundial importado na década de noventa. Assim, uma vez que o pais importa esse produto e não compõe o indice utilizado para representar os preços no mercado internacional (Cotlook $A$ ), é razoável pressupor que a nação não afeta os preços naquele mercado. Por tal razão, toma-se a relação de causalidade dos preços como unidirecional, no sentido de o mercado internacional afetar os preços domésticos.

Além disso, considera-se que exista apenas um vetor de cointegração entre essas variáveis. Apesar de ser uma imposição bastante restritiva, a pressuposição para adotá-la é de que as demais variáveis que estariam afetando essas relações estão refletidas nos preços doméstico e internacional do algodão em pluma.

\section{Os dados utilizados na análise de co-integração entre os preços do algodão em pluma nos mercados interno e externo}

No presente estudo, os preços do algodão em pluma no atacado em São Paulo, obtidos junto à Companhia Nacional de Abastecimento (CONAB) representarão os preços domésticos para realização do teste de co-integração. Os preços do algodão no mercado internacional serão representados pelo Índice Cotlook $A$, o qual fornece uma indicação do preço do algodão em pluma no mercado externo e é divulgado pelo Cotlook Limited, um serviço de informação sobre algodão localizado no Reino Unido. Serão utilizadas as médias mensais do preço à vista do algodão em pluma no atacado em São Paulo, bem como as médias mensais do Cotlook A Index para efetuar o teste co-integração. 
O periodo de análise é de janeiro de 1988 a dezembro de 1999, uma vez que em 1988 teve início o processo de abertura comercial do Brasil, intensificado a partir de 1990. Em 1988, passaram a vigorar as reduções tarifárias advindas da primeira revisão ampla na Tarifa Aduaneira Brasileira (TAB). Especificamente no caso do algodão em pluma, houve uma abrupta redução da tarifa de importação, a qual passou de $55 \%$ para $10 \%$ naquele ano. 


\section{RESULTADOS E DISCUSSÃO}

\subsection{Resultados da estimaçāo das razōes ótimas de hedge}

\subsubsection{Resultados dos testes de raiz unitária nas séries de preços}

Para estimação da razão ótima de hedge, primeiramente procedeuse a identificação dos processos autorregressivos das séries de preços à vista e futuro ${ }^{32}$. Os resultados do Akaike Information Criterion (AIC) e do Schwarz Criterion (SC), das séries de preços à vista (Indipluma) e futuro a serem utilizadas para estimar a razāo ótima de hedge para o contrato futuro da BM\&F são apresentadas na Tabela 2.

Os resultados do AIC e SC indicaram que a série de preços futuros de algodão em pluma da $\mathrm{BM} \& \mathrm{~F}$ é descrita por um processo autorregressivo de ordem um, $A R(1)$, enquanto a série de preços do Indipluma ESALQ/BM\&F é descrita por um processo autorregressivo de ordem três, AR(3).

32 Conforme salientado oportunamente na descrição dos dados, existem duas séries de preço à vista (Indipluma ESALQ/BM\&F), uma para estimar a razão ótima na BM\&F e outra para a NYCE, porque as datas de vencimento dos contratos futuros dessas Bolsas são distintas. 
Tabela 2. Resultados do AIC e SC, das séries de preços a serem utilizadas na estimação da razão ótima de hedge para o contrato futuro da BM\&F.

\begin{tabular}{ll}
\hline Série de preços futuros $B M \& F$ & $\begin{array}{l}\text { Série Indipluma para estimação } \\
\text { da razão ótima de hedge na } B M \& F\end{array}$
\end{tabular}

\begin{tabular}{ccccc}
\hline \multirow{2}{*}{$\begin{array}{c}\text { Número de } \\
\text { Defasagens }\end{array}$} & \multicolumn{2}{c}{ Critério } & \multicolumn{2}{c}{ Critério } \\
\cline { 2 - 5 } & AIC & SC & AIC & SC \\
\hline $\mathbf{1}$ & $\mathbf{- 3 8 5 , 0 1}$ & $\mathbf{- 3 7 8 , 9 1}$ & $-355,64$ & $-349,55$ \\
$\mathbf{2}$ & $-384,53$ & $-375,38$ & $-378,48$ & $-369,33$ \\
$\mathbf{3}$ & $-382,80$ & $-370,60$ & $\mathbf{- 4 1 0 , 4 9}$ & $\mathbf{- 3 9 8 , 2 9}$ \\
$\mathbf{4}$ & $-380,80$ & $-365,55$ & $-408,51$ & $-393,26$ \\
$\mathbf{5}$ & $-380,55$ & $-362,26$ & $-406,53$ & $-388,23$ \\
\hline
\end{tabular}

A Tabela 3 mostra os resultados do AIC e SC, na identificação da ordem dos processos autorregressivos das séries de preços à vista e futuro, a serem utilizadas na estimação da razão ótima de hedge para o contrato futuro da NYCE. Os menores valores encontrados com o AIC e o SC para as séries de preços à vista e futuro diferem, segundo o critério utilizado. A solução adotada para essa situação foi a utilização, primeiramente, da menor defasagem indicada (pelo AIC ou SC). Nos casos em que foi identificada autocorrelação nos residuos ao proceder-se os testes de raiz unitária, adotou-se a defasagem indicada pelo outro critério 33 .

Os resultados da Tabela 3 indicam que a série de preços futuros da NYCE é descrita por um processo autorregressivo de ordem um, $\mathrm{AR}(1)$, enquanto a série de preços do Indipluma ESALQ/BM\&F é descrita por um processo autorregressivo de ordem três, $A R(3)$.

\footnotetext{
${ }^{33}$ Os testes de raiz unitánia são sensíveis ao número de defasagens utilizado para sua realização. Por essa razão, quando o AIC e o SC indicaram defasagens diferentes, os testes neste estudo foram realizados duas vezes. Nas situações em que esse procedimento foi adotado, não houve alteração nos resultados obtidos.
} 
Tabela 3. Resultados do AIC e SC, das séries de preços a serem utilizadas na estimação da razão ótima de hedge para o contrato futuro da NYCE.

Série de preços futuros NYCE

Série Indipluma para estimação da razão ótima de hedge na NYCE

\begin{tabular}{ccccc}
\hline Número de & \multicolumn{2}{c}{ Critério } & \multicolumn{2}{c}{ Critério } \\
\cline { 2 - 5 } Defasagens & AIC & SC & AIC & SC \\
\hline $\mathbf{1}$ & $-363,58$ & $\mathbf{- 3 5 7 , 4 0}$ & $-370,61$ & $-364,44$ \\
$\mathbf{2}$ & $\mathbf{- 3 6 5 , 7 7}$ & $-356,51$ & $-393,86$ & $-384,60$ \\
$\mathbf{3}$ & $-364,67$ & $-352,32$ & $-421,55$ & $\mathbf{- 4 0 9 , 2 0}$ \\
$\mathbf{4}$ & $-363,28$ & $-347,84$ & $-421,28$ & $-405,85$ \\
$\mathbf{5}$ & $-361,59$ & $-343,08$ & $\mathbf{- 4 2 3 , 2 9}$ & $-404,77$ \\
\hline
\end{tabular}

Após a identificação da ordem dos processos autorregressivos das séries de preços, passou-se à realização dos testes de Dickey e Fuller (DF) e Dickey e Fuller Aumentado (DFA). Foi utilizado o procedimento seqüencial descrito no Apêndice 1, para verificar a significância dos componentes deterministicos e identificar a presença de raiz unitária nas séries.

Para as séries de preços futuros da BM\&F e da NYCE, descritas por processos $A R(1)$, o teste utilizado foi o de $D F$ e para as séries de preços à vista, ambas descritas por processos $\mathrm{AR}(3)$, utilizou-se o teste de DFA. Em todos os casos, pôde-se verificar, através da estatistica Q de Ljung Box, que os resíduos dos modelos estimados para realização dos testes de raiz unitária apresentaram-se não correlacionados, condição necessária à validação dos mesmos.

Os resultados dos testes de DF e DFA para as séries de preço à vista (Indipluma ESALQ/BM\&F) e futuros (BM\&F e NYCE), em nivel, são apresentados na Tabela 4. Os valores não significativos das estatísticas $\tau_{\tau}, \tau_{\beta \tau}, \phi_{3}, \tau_{\mu}, \tau_{\alpha \mu}$ e $\phi_{1}$ apresentados na referida Tabela indicam que, para as quatro séries, os elementos determinísticos tendência e constante 
não devem ser incluídos no modelo para testar a presença de raiz unitária. Nesse caso, a estatística de DF apropriada para os testes nas referidas séries é a $\tau$ (tau), cujos resultados encontram-se na última linha da Tabela 4.

Tabela 4. Resultados da identificação dos elementos determinísticos e testes de raiz unitária nas séries de preços à vista (Indipluma ESALQ/BM\&F) e futuros da BM\&F e NYCE em nivel.

\begin{tabular}{ccccc} 
& \multicolumn{4}{c}{ Séries em nivel } \\
\cline { 2 - 5 } Estatística & $\begin{array}{c}\text { Preços futuros } \\
\text { BM\&F }\end{array}$ & $\begin{array}{c}\text { Indipluma (razão } \\
\text { ótima BM\&F) }\end{array}$ & $\begin{array}{c}\text { Preços futuros } \\
\text { NYCE }\end{array}$ & $\begin{array}{c}\text { Indipluma (razão } \\
\text { ótima NYCE) }\end{array}$ \\
\hline$\tau_{\tau}$ & $\mathrm{t}=-2,44$ & $\mathrm{t}=-2,58$ & $\mathrm{t}=-1,94$ & $\mathrm{t}=-2,84$ \\
$\tau_{\beta \tau}$ & $\mathrm{t}=-2,33$ & $\mathrm{t}=-2,37$ & $\mathrm{t}=-2,12$ & $\mathrm{t}=-2,66$ \\
$\phi_{3}$ & $\mathrm{~F}=3,00$ & $\mathrm{~F}=3,45$ & $\mathrm{~F}=2,30$ & $\mathrm{~F}=4,12$ \\
$\tau_{\mu}$ & $\mathrm{t}=-0,75$ & $\mathrm{t}=-1,12$ & $\mathrm{t}=-0,35$ & $\mathrm{t}=-1,07$ \\
$\tau_{\alpha \mu}$ & $\mathrm{t}=0,69$ & $\mathrm{t}=1,05$ & $\mathrm{t}=0,31$ & $\mathrm{t}=1,00$ \\
$\phi_{1}$ & $\mathrm{~F}=1,06$ & $\mathrm{~F}=1,84$ & $\mathrm{~F}=0,97$ & $\mathrm{~F}=1,78$ \\
$\tau$ & $\mathbf{t}=\mathbf{- 1 , 2 8}$ & $\mathbf{t}=\mathbf{- 1 , 6 1}$ & $\mathbf{t}=-\mathbf{1 , 3 6}$ & $\mathbf{t}=\mathbf{- 1 , 6 0}$
\end{tabular}

Notas: os valores críticos para as estatísticas DF são apresentados em Fuller (1996) e Dickey \& Fuller (1981). O tamanho da amostra utilizado para realização dos testes foi 250 .

Os resultados dos testes de DF e DFA relativos à estatística $\tau$ mostram que os valores são não significativos estatisticamente, indicando a presença de raiz unitária em todas as séries em nivel. Por essa razão, os mesmos foram realizados novamente, utilizando-se as séries de preços nas primeiras diferenças, com uma defasagem a menos na especificação dos modelos a serem testados.

A Tabela 5 mostra os resultados dos testes DF e DFA para as séries de preços à vista e futuro na primeira diferença. As séries de preços à vista (Indipluma) e futuros (BM\&F e NYCE), apresentaram-se 
estacionárias na primeira diferença, visto que, para todas elas, a hipótese de raiz unitária foi rejeitada ao nivel de significância de $1 \%$.

Tabela 5. Resultados dos testes de raiz unitária para as séries de preços à vista (Indipluma ESALQ/BM\&F) e futuros da BM\&F e NYCE na primeira diferença.

Séries na primeira diferença

\begin{tabular}{cccccc}
\hline Estatística & $\begin{array}{c}\text { Valor crítico } \\
(1 \%)\end{array}$ & $\begin{array}{c}\text { Preços fut. } \\
\text { BM\&F }\end{array}$ & $\begin{array}{c}\text { Indipluma (razão } \\
\text { ótima BM\&F) }\end{array}$ & $\begin{array}{c}\text { Preços fut. } \\
\text { NYCE }\end{array}$ & $\begin{array}{c}\text { Indipluma (razão } \\
\text { ótima NYCE) }\end{array}$ \\
\hline$\tau$ & $-2,58$ & $\mathrm{t}=-11,1^{*}$ & $\mathrm{t}=-11,08^{*}$ & $\mathrm{t}=-10,89^{*}$ & $\mathrm{t}=-10,82^{*}$
\end{tabular}

Notas: os valores criticos para a estatística $\tau$ são apresentados em Fuller (1996); o tamanho da amostra utilizado para realização dos testes foi 250; * valor significativo a $1 \%$.

\subsubsection{Resultados dos testes para verificar a hipótese de mercado futuro eficiente}

Uma vez constatada a estacionariedade das séries de preços na primeira diferença, procedeu-se a verificação da hipótese de mercado futuro eficiente para as séries de preços futuros da BM\&F e da NYCE, a fim de estimar a razão ótima de hedge. Conforme sugerido por Saboya \& Bacchi (1999), foram utilizados testes de raiz unitária para analisar a eficiência dos mercados futuros.

A hipótese de mercado futuro eficiente pressupōe que os preços futuros comportem-se como processos AR(1). De acordo com os resultados obtidos através do AIC e $\mathrm{SC}$, as séries de preços futuros da BM\&F e da NYCE são descritas por processos AR(1).

A equação (12) mostra o comportamento dos preços em um mercado futuro eficiente, onde os preços futuros na primeira diferença devem ser descritos por uma série ruído branco. Assim, na estimação por Minimos Quadrados Ordinários (MQO) de um modelo AR(1) dos 
preços futuros na primeira diferença, conforme aquele descrito na equação (27) a seguir, os coeficientes dos termos constante $\left(a_{0}\right) \mathrm{e}$ tendência deterministica $\left(a_{1}\right)$, bem como da variável preço futuro defasada de um periodo (b) devem ser estatisticamente não significativos para que o mercado futuro seja eficiente:

$$
\Delta f_{t}=a_{0}+a_{1} T+b f_{t-1}+u_{t}
$$

onde $\Delta f_{t}$ é o preço futuro na primeira diferença, $f_{t-1}$ é o preço futuro no momento $t-1, T$ é a tendência determinística e $u_{t}$ é uma série ruído branco. Assim, sob a hipótese nula deve-se ter $a_{0}=a_{1}=b=0$, para que o mercado futuro seja eficiente.

A significância dos coeficientes da equação (27) estimada por MQO para os preços futuros da BM\&F e da NYCE foram testados de acordo com o procedimento seqüencial apresentado no Apêndice 1 e os resultados são apresentados na Tabela 6 .

Os resultados dos testes referentes às estatísticas $\tau_{\tau}, \tau_{\beta \tau}, \phi_{3}, \tau_{\mu}, \tau_{\alpha \mu}$ e $\phi_{1}$ apresentados na Tabela 6 indicam que os coeficientes das variáveis constante e tendência são não significativos para as séries de preços futuros da BM\&F e NYCE na primeira diferença. Assim sendo, estimouse o modelo (27) sem os elementos deterministicos, a fim de testar a presença de raiz unitária nas referidas séries. Para tal, a estatística de DF utilizada no teste foi a $\tau$ (tau).

Conforme pode ser observado na última linha da Tabela 6 , os valores relativos à estatística $\tau$ apresentaram-se não significativos, indicando a não rejeição da hipótese nula para as séries de preços futuros da BM\&F e NYCE na primeira diferença. Assim, não se pode rejeitar a hipótese de que $a_{0}=a_{1}=b=0$ e os mercados futuros de 
algodão em pluma da BM\&F e da NYCE podem ser considerados eficientes, durante o periodo analisado.

Tabela 6. Resultados da verificação da hipótese de mercado futuro eficiente para os preços futuros da BM\&F e da NYCE.

\begin{tabular}{cccc}
\hline Estatistica & Hipótese nula & $\begin{array}{c}\text { Preços futuros } \\
\text { BM\&̊F (1a diferença) }\end{array}$ & $\begin{array}{c}\text { Preços futuros } \\
\text { NYCE (1a diferença) }\end{array}$ \\
\hline$\tau_{\tau}$ & $\mathrm{b}=0$ & $\mathrm{t}=-2,45$ & $\mathrm{t}=-1,94$ \\
$\tau_{\beta \tau}$ & $\mathrm{a}_{1}=0$, dado $\mathrm{b}=0$ & $\mathrm{t}=-2,33$ & $\mathrm{t}=-2,12$ \\
$\phi_{3}$ & $\mathrm{~b}=\mathrm{a}_{1}=0$ & $\mathrm{~F}=3,00$ & $\mathrm{~F}=2,30$ \\
$\tau_{\mu}$ & $\mathrm{b}=0$ & $\mathrm{t}=-0,75$ & $\mathrm{t}=-0,35$ \\
$\tau_{\alpha \mu}$ & $\mathrm{a}_{0}=0$, dado $\mathrm{b}=0$ & $\mathrm{t}=0,69$ & $\mathrm{t}=0,31$ \\
$\phi_{1}$ & $\mathrm{a}_{0}=\mathrm{b}=0$ & $\mathrm{~F}=1,06$ & $\mathrm{~F}=0,97$ \\
$\tau$ & $\mathbf{b}=\mathbf{0}$ & $\mathbf{t}=\mathbf{- 1 , 2 8}$ & $\mathbf{t}=\mathbf{- 1 , 3 6}$
\end{tabular}

Notas: os valores criticos para as estatísticas DF são apresentados em Fuller (1996) e Dickey \& Fuller (1981); o tamanho da amostra utilizado para realização dos testes foi 250 .

\subsubsection{Resultados das estimativas das razões ótimas de hedge}

Após verificar a eficiência dos mercados futuros da BM\&F e da NYCE, procedeu-se a estimação da razão ótima de hedge para os contratos futuros de algodão em pluma dessas Bolsas. De acordo com o enfoque de Myers \& Thompson (1989), as estimativas da razão ótima de hedge devem ser feitas utilizando-se as séries de preços nas primeiras diferenças, quando as mesmas tornam-se estacionárias.

Além disso, deve-se incluir o preço à vista na primeira diferença, defasado de um e de dois periodos, como variáveis explicativas nas regressões da razão ótima de hedge para o contrato futuro da BM\&F e da NYCE, pois as séries do Indipluma na primeira diferença são descritas, em ambos os casos, por processos AR(2). Assim, o modelo a ser estimado em cada caso é aquele representado pela equação (28): 


$$
\Delta p_{t}=\alpha+\delta \Delta f_{t}+\beta \Delta p_{t-1}+\gamma \Delta p_{t-2}+u_{t}
$$

sendo:

$\Delta p_{t}=$ preço à vista do algodão em pluma na primeira diferença (Indipluma ESALQ/BM\&F) no momento $t$;

$\delta$ = razão ótima de hedge;

$\Delta f_{t}=$ preço futuro do algodão em pluma na primeira diferença no momento $t$ (BM\&F ou NYCE);

$\Delta p_{t-1}=$ preço à vista do algodão em pluma na primeira diferença (Indipluma ESALQ/BM\&F) no momento $t-1$;

$\Delta p_{t-2}=$ preço à vista do algodão em pluma na primeira diferença (Indipluma ESALQ/BM\&F) no momento $t-2$;

$u_{t}=$ ruído branco.

Os resultados das estimativas das razões ótimas de hedge para os contratos futuros da BM\&F e da NYCE são apresentados na Tabela 7 . Pode-se observar, através do teste $F$, que ambas as regressões estimadas apresentaram-se significativas. Para o contrato futuro de algodão em pluma da $B M \& F$, o coeficiente que representa a razão ótima de hedge ( $\delta$ ) apresentou-se significativo. O valor obtido indica que a proporção da posição à vista a ser compensada com esses contratos, a fim de minimizar o risco das posiçōes à vista e futura, é 40,42\%

\footnotetext{
${ }^{34}$ Essa é uma estimativa teórica, baseada em valores ex post. Na elaboração de estratégias de redução do risco de preço, a tomada de posições em mercados futuros deve levar em consideração outros fatores relevantes.
} 
Tabela 7. Resultados das estimativas das razões ótimas de hedge para os contratos futuros de algodão em pluma da BM\&F e da NYCE.

\begin{tabular}{ccc}
\hline & Contrato futuro BM\&F & Contrato futuro NYCE \\
\hline Análise de Regressão & $\mathrm{F}=40,44^{*}$ & $\mathrm{~F}=21,95^{*}$ \\
\hline Variáveis & \multicolumn{2}{c}{ Coeficientes } \\
\hline Constante & $-0,001767(-1,14)$ & $-0,002696^{* * *}(-1,61)$ \\
$\Delta$ & $0,4042^{*}(5,86)$ & $-0,04944(-0,75)$ \\
$\Delta p_{t-1}$ & $0,4385^{*}(6,48)$ & $0,5253^{*}(7,29)$ \\
$\Delta p_{t-2}$ & $-0,3937^{*}(-5,93)$ & $-0,4125^{*}(-5,62)$ \\
\hline $\begin{array}{l}\text { Notas: } \\
\text { significativo a } 1 \% ;{ }^{* * *} \text { significativo a } 10 \% .\end{array}$ & encontram-se & entre parênteses; *
\end{tabular}

Entretanto, para o contrato futuro de algodão em pluma da NYCE, o coeficiente que representa a razão ótima de hedge $(\delta)$ apresentou-se não significativo, indicando que a operação de cross hedge através desse instrumento não é um mecanismo eficaz de administração de risco de preço para o algodão em pluma brasileiro.

No caso da regressão com os preços do contrato futuro da BM\&F, todos os coeficientes apresentaram-se estatisticamente significativos, inclusive aquele que representa a razão ótima de hedge, indicando a existência de correlação entre as variações nos preços à vista e futuro no Brasil.

O coeficiente que representa a razão ótima de hedge para o contrato futuro da NYCE apresentou-se não significativo, mas através do teste F, pode-se rejeitar a hipótese nula de que $\alpha=\delta=\beta=\gamma=0$ ao nível de $1 \%$ de significância. Isso indica que, na estimação da razão ótima de hedge para o contrato futuro da NYCE, as variações no preço à vista estão sendo explicadas apenas pelas variáveis defasadas do preço à vista na primeira diferença.

Portanto, as variações do preço à vista no Brasil não estariam correlacionadas com as variações do preço futuro na NYCE, pelo menos 
no curto prazo e as tentativas de reduzir o risco de preço do algodão em pluma brasileiro através da utilização de contratos futuros da NYCE não seriam eficazes.

A estimação da razão ótima de hedge no presente estudo refere-se ao periodo de janeiro de 1997 a dezembro de 1999. Entretanto, dois fatos ocorridos no decorrer de 1999 podem estar afetando os resultados obtidos nesta análise.

Primeiramente, a desvalorização cambial e a mudança para o regime de taxas de câmbio flutuantes em janeiro afetou as cotações em dólar do algodão em pluma nacional. Entre janeiro e fevereiro, enquanto os preços em Reais subiam, as cotações em dólar decresciam (Figura 12). Em segundo lugar, em março de 1999, a BM\&F alterou a forma de liquidação do contrato, que passou a ser por entrega fissica. Ao longo daquele ano, a liquidez do mercado futuro de algodão em pluma foi extremamente baixa, o que pode implicar em menor volatilidade das cotações.

Considerando-se esses aspectos, procedeu-se a estimativa da razão ótima de hedge para os contratos da $\mathrm{BM} \& \mathrm{~F}$ e da $\mathrm{NYCE}$, utilizandose os mesmos dados da estimativa já realizada, exceto aqueles referentes ao ano de 1999. Os resultados do AIC e SC, bem como dos testes de raiz unitária nas séries de preços são apresentados no Apêndice 2. Os resultados das estimativas das razões ótimas de hedge encontram-se na Tabela 8.

Para o periodo 07 de janeiro de 1997 a 30 de dezembro de 1998, o coeficiente que representa a razão ótima de hedge para o contrato futuro da NYCE apresentou-se novamente não significativo, indicando que esse instrumento não é eficaz na administração do risco de preço do produto brasileiro. 
Tabela 8. Resultados das estimativas das razões ótimas de hedge para os contratos futuros de algodão em pluma da BM\&F e da NYCE, excluindo-se o ano de 1999.

\begin{tabular}{ccc}
\hline & Contrato futuro BM\&F & Contrato futuro NYCE \\
\hline Anålise de Regressão & $\mathrm{F}=78,17^{*}$ & $\mathrm{~F}=53,15^{*}$ \\
\hline Variáveis & \multicolumn{2}{c}{ Coeficientes } \\
\hline Constante & $-0,0005062(-0,77)$ & $-0,0005393(-0,77)$ \\
$\delta$ & $0,1730^{*}(4,94)$ & $0,007032(0,23)$ \\
$\Delta p_{t-1}$ & $0,6304^{*}(9,83)$ & $0,6983^{*}(10,13)$ \\
\hline
\end{tabular}

Notas: os valores da estatística $t$ encontram-se entre parênteses; * significativo a 1\%.

Já para a BM\&F, o coeficiente estimado apresentou-se estatisticamente significativo a $1 \%$ e igual a 0,1730 . Esse valor indica que a proporção da posição à vista a ser compensada com os contratos futuros daquela Bolsa para minimizar o risco das posições à vista e futura é $17,3 \%$. Tal proporção é bastante inferior àquela obtida quando o ano de 1999 é incluído na análise (40,42\%).

A efetividade do hedge para os contratos futuros foi calculada de acordo com a equação (6). Visto que o coeficiente da razão ótima de hedge para o contrato futuro da NYCE apresentou-se não significativo nos dois períodos considerados, a efetividade do hedge é igual a zero naquela Bolsa.

Para o contrato futuro da BM\&F, calculou-se a efetividade do hedge para o periodo que inclui o ano de 1999 e para o periodo que o exclui. O valor obtido foi 0,225 para o periodo que inclui o ano de 1999 e indica que a tomada de posição em contratos futuros de algodão em pluma na $B M \& F$ na proporção da razão ótima de hedge $(40,42 \%)$ reduziria o risco do retorno em $22,5 \%$, durante o periodo de janeiro de 1997 a dezembro de 1999. 
Quando o ano de 1999 foi excluído, a efetividade do hedge resultou em 0,16 , indicando uma redução de $16 \%$ no risco do retorno, pela tomada de posições em contratos futuros na proporção da razão ótima de hedge $(17,3 \%)$, durante o período de janeiro de 1997 a dezembro de 1998.

Os resultados da análise comprovam que a razão ótima de hedge varia de acordo com o período considerado, conforme esperado. Entretanto, o aspecto mais importante dos resultados não está no valor obtido para a proporção da razão ótima de hedge, visto que a análise é ex post, mas na constatação de que o contrato futuro de algodão em pluma da $B M \& F$ tem sido um instrumento efetivo de administração de risco de preço para o algodão brasileiro, embora a redução no risco não tenha sido elevada.

Conforme visto, diversos fatores podem estar levando os preços à vista no Brasil e futuro na NYCE a não evoluir conjuntamente, entre eles a) períodos distintos de colheita do algodão nos hemisférios Norte e Sul (as safras brasileira e argentina concentram-se no primeiro semestre do $a^{35}{ }^{35}$, enquanto a norte-americana concentra-se no segundo); b) o produto brasileiro e aquele negociado na NYCE não apresentam características idênticas; c) a NYCE reflete as condições de oferta e demanda de algodão em pluma no mercado norte americano, grandemente influenciadas por politicas governamentais de suporte de renda à agricultura. Dessa forma, o mercado futuro da NYCE refletiria em grande parte as condições regionais do mercado doméstico dos Estados Unidos.

\footnotetext{
${ }^{35}$ Conforme salientado anteriormente, essa situação vem se modificando, pois o Mato Grosso, principal estado produtor brasileiro, concentra sua colheita no início do segundo semestre do ano.
} 
Nesse contexto, o desenvolvimento do mercado futuro de algodão da $B M \& F$ poderia servir como um referencial de preço para os paises do MERCOSUL, visto que as safras nesses paises ocorrem no primeiro semestre do ano e parte significativa das importações brasileiras são originárias da Argentina e Paraguai. Assim, o mercado futuro da BM\&F poderia refletir melhor as condições de oferta e demanda sul americanas.

Contudo, é importante salientar a interferência governamental na comercialização de algodão no Brasil, através de leilões de Prêmio de Escoamento de Produto (PEP) e opções sobre a venda de algodão em pluma. Sem dúvida, esse aspecto dificulta sobremaneira o desenvolvimento do mercado futuro de algodão no Brasil, porque se as ações do governo reduzem a incerteza com relação aos preços futuros ou alteram com freqüência as caracteristicas do mercado dificultando sua previsibilidade, não há condições para o sucesso de um contrato futuro (Teixeira, 1992).

E, finalmente, embora não tenha sido constatada correlação entre o preço à vista no Brasil e o preço futuro na NYCE no curto prazo, é possivel que o contrato dessa Bolsa possa ser utilizado, juntamente com o contrato futuro da $\mathrm{BM} \& \mathrm{~F}$, em estratégias de redução do risco de preço pelos agentes brasileiros.

A existência de mais de um contrato futuro para a mesma commodity possibilita operações de arbitragem entre Bolsas, chamadas intermaketing spread. As operações de arbitragem do tipo spreading são caracterizadas por baixo risco e constituem uma estratégia adicional de administração do risco de preço do algodão em pluma no Brasil, algo que não será abordado neste estudo. 


\subsection{Resultados da análise da relação entre as importações financiadas de algodão em pluma e a arbitragem das taxa de juros nos mercados interno e externo}

A Figura 15 mostra a evolução dos diferenciais entre a taxa de retorno de uma aplicação em real descontada a variação cambial [para o CDB e custo do financiamento do capital de giro (FCG)] e o custo de captação de recursos externos, juntamente com o valor das importações financiadas de algodão em pluma, no periodo 1996 a 1999. A Figura 16 apresenta os diferenciais entre a taxa real de juros no mercado interno (para o CDB e custo do financiamento do capital de giro) e o custo de captação de recursos externos, com o valor das importações financiadas de algodão em pluma no mesmo periodo.

Foram realizados testes de raiz unitária para todas as séries apresentadas nas Figuras 15 e 16, a fim de proceder-se a análise de regressão entre o diferencial das taxas de juros nos mercados interno e externo e as importações financiadas de algodão em pluma, sob cada forma de pagamento.

Os resultados do AIC e do SC, utilizados para determinar a ordem dos processos autorregressivos das séries dos diferenciais das taxas de juros nos mercados interno e externo $\left(\begin{array}{lll}d_{1} & \mathrm{e} & d_{2}\end{array}\right)$ bem como das importações financiadas de algodão em pluma, são apresentados, respectivamente, nos Apêndices 3 e 4. 


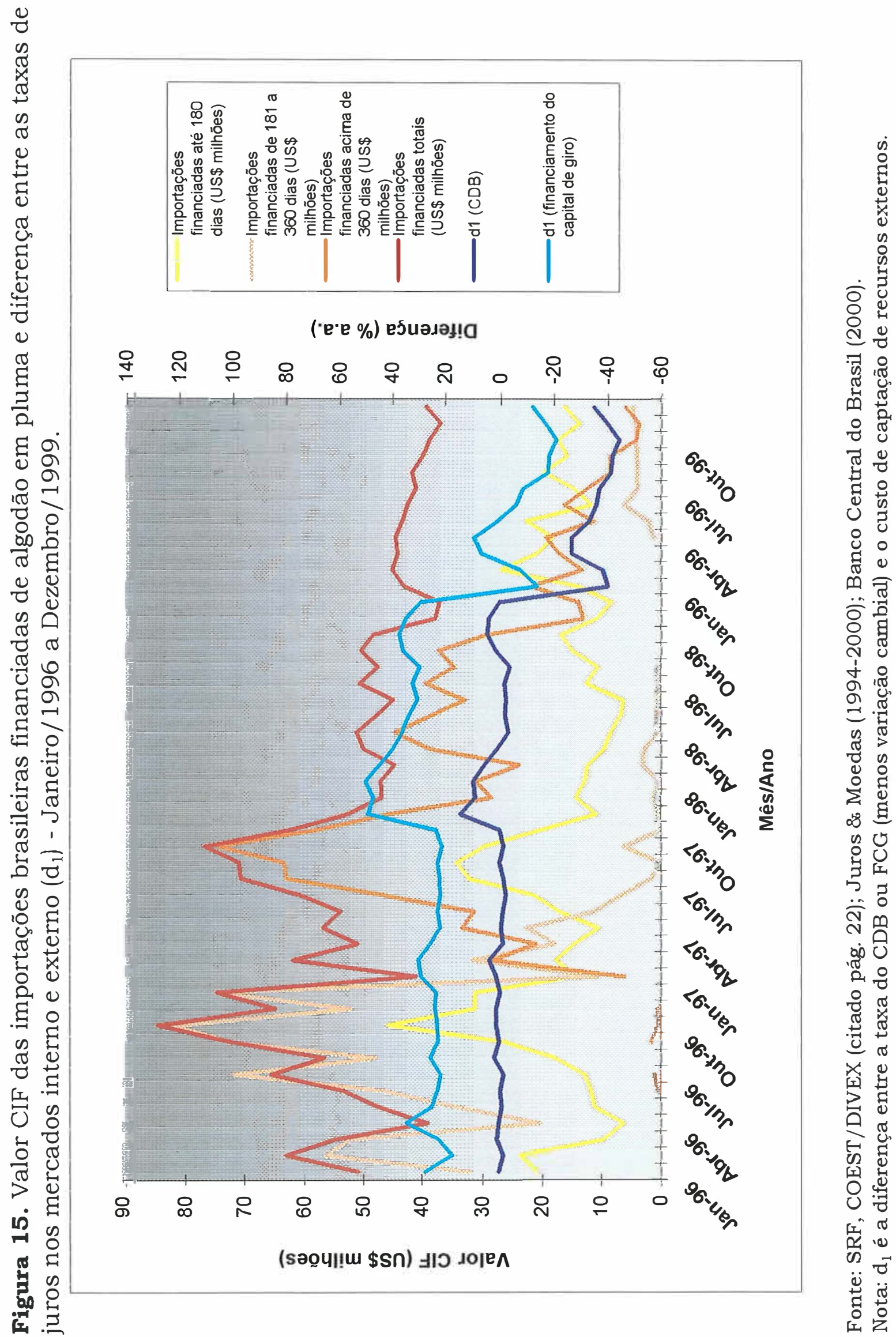




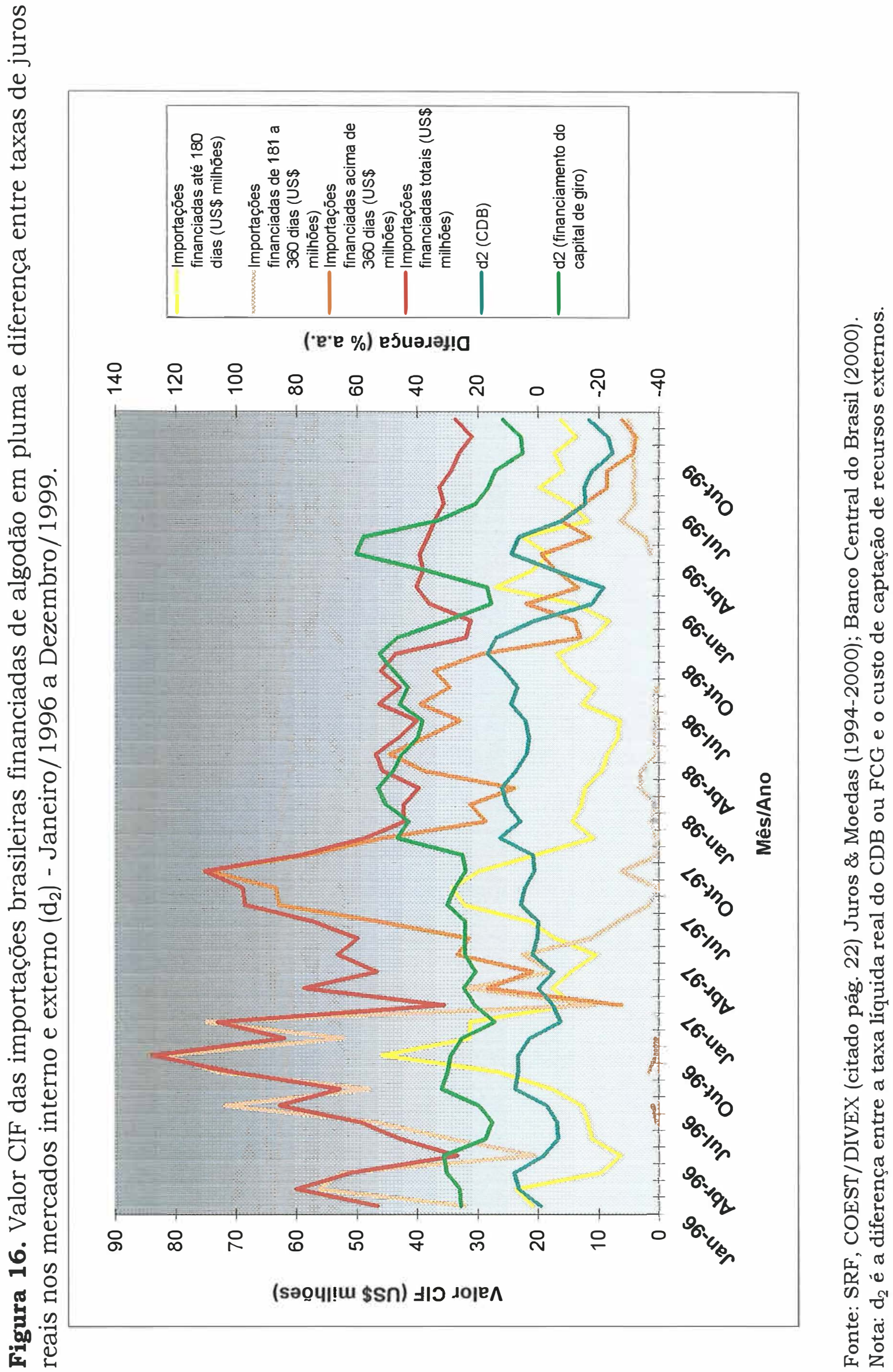


Os valores do AIC e SC indicam que os diferenciais $d_{1}$ (para o $\mathrm{CDB}$ e custo do financiamento do capital de giro) comportam-se como processos autorregressivos de ordem um [AR(1)], enquanto o diferencial $d_{2}$ comporta-se como um $\mathrm{AR}(3)$ para o $\mathrm{CDB}$ e como um $\mathrm{AR}(2)$ para o custo do financiamento do capital de giro.

Quanto às séries das importações financiadas de algodão em pluma, os resultados do AIC e SC indicam que as séries das importações financiadas totais e aquelas com prazo de pagamento de 181 a 360 dias são descritas por processos $\mathrm{AR}(9)$, enquanto as séries referentes às importações financiadas com prazo de pagamento até 180 dias e acima de 360 dias correspondem a processos $\mathrm{AR}(1)$.

Após a identificação da ordem dos processos autorregressivos das séries dos diferenciais entre as taxas de juros nos mercados interno e externo $\left(d_{1}\right.$ e $\left.d_{2}\right)$ e das séries das importações financiadas de algodão em pluma, procedeu-se os testes para verificar a presença de raiz unitária.

Nas séries $d_{1}$, optou-se por utilizar o teste de raiz unitária com mudança estrutural, descrito no Apêndice 5. Tal método foi adotado porque detectou-se uma possivel mudança no nivel das séries $d_{1}$ (para o $\mathrm{CDB}$ e custo do financiamento do capital de giro) a partir de janeiro de 1999 (Figura 15). Quando os testes DF e DFA são utilizados na presença de mudanças estruturais, eles são viesados para não rejeitar a hipótese de raiz unitária (Enders, 1995).

O procedimento seqüencial descrito no Apêndice 1 foi utilizado para verificar a significância dos componentes determinísticos e identificar a presença de raiz unitária nas séries $d_{2}$ e importações financiadas de algodão em pluma.

Os resultados dos testes de raiz unitária para as séries dos diferenciais $d_{1}$ (para o $\mathrm{CDB}$ e custo do financiamento do capital de giro) são mostrados na Tabela 9. Os valores significativos dos testes 
apresentados na referida Tabela indicam que as séries são estacionárias em nivel.

Tabela 9. Resultados dos testes de raiz unitária com mudança estrutural para as séries dos diferencias $d_{1}$.

\begin{tabular}{|c|c|}
\hline \multicolumn{2}{|c|}{ Séries em nivel } \\
\hline$d_{1}$ (CDB) & $d_{I}$ (Financiamento Capital de Giro) \\
\hline$t=3,63^{* * *}$ & $t=5,75^{*}$ \\
\hline $\begin{array}{l}\text { Votas: os valores } \\
\text { jalor significativo a } \\
\text { da quebra em rela } \\
\text { dos testes foi } 0,7\end{array}$ & $\begin{array}{l}\text { do apresentadas em Perron (1989); * } \\
\text { valor significativo a } 10 \% \text {. O momento } \\
\text { nanho da amostra }(\lambda) \text { para realização }\end{array}$ \\
\hline
\end{tabular}

A Tabela 10 mostra os resultados dos testes para verificar a presença de raiz unitária nas séries dos diferenciais $d_{2}$ (para o CDB e custo do financiamento do capital de giro). Pode-se observar, através dos valores significativos dos testes, que as séries $d_{2}$ também são estacionárias em nível.

Tabela 10. Resultados da identificação dos elementos determinísticos e testes de raiz unitária nas séries dos diferencias $d_{2}$.

Séries em nivel

\begin{tabular}{ccc}
\hline Estatistica & $\boldsymbol{d}_{2}$ (CDB) & $\boldsymbol{d}_{2}$ (Financiamento Capital de Giro) \\
\hline$\tau_{\tau}$ & $\mathrm{t}=-2,23$ & $\mathrm{t}=-3,45$ \\
$\tau_{\beta \tau}$ & $\mathrm{t}=-1,27$ & $\mathrm{t}=0,29$ \\
$\phi_{3}$ & $\mathrm{~F}=2,67$ & $\mathrm{~F}=6,06$ \\
$\tau_{\mu}$ & $\mathrm{t}=-1,92$ & $\mathbf{t}=\mathbf{- 3 , 5 1}$ \\
$\tau_{\alpha \mu}$ & $\mathrm{t}=-0,46$ & \\
$\phi_{1}$ & $\mathrm{~F}=2,02$ & \\
$\tau$ & $\mathbf{t}=\mathbf{- 1 , 9 8 *}$ &
\end{tabular}

Notas: os valores criticos para as estatísticas DF são apresentados em Fuller (1996) e Dickey \& Fuller (1981); ** valor significativo a 5\%. O tamanho da amostra utilizada para realização dos testes foi 50 . 
Quanto às séries das importações financiadas de algodão em pluma, os resultados dos testes de raiz unitária são apresentados na Tabela 11. Os valores obtidos nos testes indicam que as séries referentes aos prazos de pagamento até 180 dias, de 181 a 360 dias e importações financiadas totais são estacionárias em nivel. Com relação à série com prazo de pagamento acima de 360 dias, a mesma apresentou-se não estacionária em nivel, mas estacionária na primeira diferença.

Tabela 11. Resultados da identificação dos elementos determinísticos e testes de raiz unitária para as séries das importações financiadas de algodão em pluma.

\begin{tabular}{|c|c|c|c|c|c|}
\hline \multirow[b]{2}{*}{ Estatistica } & \multicolumn{4}{|c|}{ Séries em nivel } & \multirow{2}{*}{$\begin{array}{c}\begin{array}{c}\text { Série na } 1^{a} \\
\text { diferença }\end{array} \\
\text { Acima de } 360 \text { dias }\end{array}$} \\
\hline & Até 180 dias & $\begin{array}{c}\text { De } 181 \text { a } 360 \\
\text { dias }\end{array}$ & $\begin{array}{c}\text { Acima de } 360 \\
\text { dias }\end{array}$ & $\begin{array}{l}\text { Importaçōes } \\
\text { financ. totais }\end{array}$ & \\
\hline$\tau_{\tau}$ & $\mathrm{t}=-3,08$ & $t=-5,69 \star$ & $t=-1,35$ & $\mathrm{t}=-3,11$ & $t=-6,55^{\star}$ \\
\hline$\tau_{\beta \tau}$ & $t=-0,47$ & & $t=-0,90$ & $t=-3,20 *$ & \\
\hline$\phi_{3}$ & $F=4,76$ & & $F=1,58$ & & \\
\hline$\tau_{\mu}$ & $t=-3,08^{\star t}$ & & $t=-1,54$ & & \\
\hline$\tau_{\alpha \mu}$ & & & $\mathrm{t}=1,2$ & & \\
\hline$\phi_{1}$ & & & $F=1,18$ & & \\
\hline$\tau$ & & & $\mathrm{t}=-0,95$ & & \\
\hline
\end{tabular}

Notas: os valores criticos para as estatisticas DF são apresentados em Fuller (1996) e Dickey \& Fuller (1981); * valor significativo a $1 \%$; $* *$ valor significativo a $5 \%$. O tamanho da amostra utilizada para realização dos testes foi 50.

Tendo em vista que, com exceção das importações financiadas com prazo de pagamento acima de 360 dias, todas as demais séries apresentaram-se estacionárias em nivel, foram realizadas análises de regressão de cada série estacionária das importações financiadas de algodão em pluma em nivel contra cada série dos diferenciais entre as 
de juros nos mercados interno e externo em nivel, a fim de verificar a existência de uma relação entre essas variáveis.

Foram testados diversos modelos, cada um especificado da seguinte forma: a) apenas a variável independente defasada; b) variável independente defasada e inclusão de uma variável binária, de acordo com a identificação de possiveis mudanças estruturais na série; c) variável independente defasada e inclusão de variáveis binárias anuais (para distinguir as importações a cada ano); d) variável independente defasada e tendência. Em todos os modelos testados, incluiu-se uma constante e também a variável dependente defasada de um a três períodos, para eliminar a autocorrelação nos resíduos da regressão.

Em cada modelo especificado, testou-se a variável independente (diferencial entre as taxas de juros nos mercados interno e externo) defasada de 6 até 12 periodos, isto é, cada defasagem foi testada em uma especificação diferente. Adotou-se a defasagem minima de seis periodos (equivalente a seis meses) porque o prazo entre a contratação da importação e a chegada do algodão ao Brasil, em geral, não é inferior a seis meses.

Os modelos foram selecionados de acordo com o critério da qualidade de ajustamento $\left(\overline{\mathrm{R}}^{2}\right)$. Assim, de acordo com o modelo selecionado, foram estimadas regressões entre cada série das importações financiadas (variável dependente) e cada série do diferencial das taxas de juros interna e externa (variável independente) nas sucessivas defasagens (6 até 12 ).

Então, para cada série das importações financiadas (até 180 dias, de 180 a 360 dias e totais) foram estimadas vinte e oito regressões (quatro vezes sete, ou seja, uma correspondente a cada série do diferencial entre as taxas de juros nos mercados interno e externo - $\mathrm{d}_{1}$ para o $C D B, d_{1}$ para o financiamento do capital de giro, $d_{2}$ para o CDB e 
$\mathrm{d}_{2}$ para o financiamento do capital de giro - e sete defasagens testadas 6 até 12 - para cada série).

Os resultados das estimativas, testando-se cada defasagem da variável independente no modelo selecionado são apresentados nos Anexos. Através dos resultados obtidos, não foi possível comprovar a existência de uma relação entre as variáveis analisadas, uma vez que, em todas as regressões, a variável independente defasada (diferencial entre as taxas de juros) apresentou-se estatisticamente não significativa.

Tais resultados podem ter duas explicações: a) inexistência de uma relação entre essas variáveis; b) existência de uma relação não identificada, devido à dificuldade de isolar as variáveis na análise, dado que seu comportamento é condicionado por muitas outras variáveis econômicas e por aspectos inerentes às importações e ao financiamento das mesmas. Essas possibilidades serão discutidas em maiores detalhes a seguir.

As operações de arbitragem entre as taxas de juros interna e externa ocorrem devido à existência de um diferencial entre as mesmas e à oferta de prazos de pagamento bastante dilatados no mercado internacional.

No mercado interno, a quase totalidade das compras de algodão em pluma é realizada à vista. Porém, as empresas que não podem ou não desejam pagar à vista pela aquisição de matéria-prima acabam optando por importar o produto por causa dos longos prazos de pagamento ofertados no mercado externo.

Então, mesmo se a diferença entre a taxa de juros doméstica e o custo de captação de recursos externos não for expressiva, os prazos para saldar a aquisição do algodão importado em comparação com as compras predominantemente à vista do produto brasileiro podem 
constituir-se na razão principal para importar essa fibra, isto é, estarse-ia importando, além de algodão em pluma, "prazos de pagamento".

Nesse caso, a existência de um diferencial entre as taxas de juros nos mercados interno e externo no momento da contratação da importação poderia vir a constituir-se numa vantagem adicional aos prazos dilatados de pagamento e não no motivo que explicaria as importaçōes financiadas de algodão em pluma. Na ausência desse diferencial, o produto provavelmente seria importado da mesma forma.

Assim sendo, existe a possibilidade de que as importaçōes de algodão em pluma estejam mais relacionadas aos prazos de pagamento vigentes no mercado internacional do que ao diferencial entre as taxas de juros interna e externa. Em tal situação, não seria detectada uma relação entre o diferencial dessas taxas e as importaçōes financiadas do produto.

Além disso, a evolução das variáveis utilizadas na análise reflete tanto a conjuntura macroeconômica interna como o cenário internacional. Dessa forma, a vinculação entre a arbitragem das taxas de juros nos mercados interno e externo e as importaçōes financiadas de algodão em pluma pode estar restrita às oportunidades surgidas em curtos periodos de tempo, não sendo possivel detectar um comportamento sistemático, ou seja, uma relação entre as mesmas ao longo do tempo.

A evolução da economia brasileira no período analisado foi pautada por medidas visando a manutenção do ambiente de estabilização inflacionária, frente às turbulências nos cenários interno e externo. A alteração da conjuntura externa, a condução da política monetária e gestão fiscal, bem como da política cambial, foram determinantes do comportamento das variáveis analisadas neste estudo. 
Durante todo o período de 1996 a 1999, as conjunturas interna e externa levaram à adoção de medidas que alteraram o regulamento das importaçōes brasileiras, em especial o pagamento daquelas financiadas com prazo até 360 dias. Paralelamente, houve modificação nas alíquotas de importação do algodão em pluma, através de cronograma estabelecido previamente com os países do MERCOSUL (seção 3.3).

O cenário internacional e as crises de credibilidade em relação aos mercados emergentes durante o período considerado também condicionaram os prazos oferecidos e o custo de captação de recursos externos para as operaçōes de crédito comercial. Além disso, o Banco Central editou vários normativos alterando aspectos relativos à Resolução $n^{\circ}$ 63/1967, a qual faculta aos bancos de investimento, desenvolvimento e comerciais autorizados a operar em câmbio, a contratação direta de empréstimos externos destinados a serem repassados a empresas no país ${ }^{36}$.

Assim sendo, em alguns momentos compreendidos no período de 1996 a 1999, as conjunturas internas e externas originaram oportunidades de arbitragem entre as taxas de juros nesses mercados, através da importação de algodão em pluma. Entretanto, a alteração dos cenários doméstico e internacional faz com que essas oportunidades não persistam, não caracterizando tais operaçōes como um comportamento sistemático ao longo do tempo.

Ademais, o fato de não ter sido detectada uma relação entre as variáveis nas análises econométricas pode estar refletindo a dificuldade de se captar alguns fatores relacionados às características operacionais da importação de algodão em pluma e à seletividade na concessão de crédito para essas operaçōes. Esses aspectos, os quais podem estar

\footnotetext{
${ }^{36}$ No Apêndice 6 são enumeradas algumas das Resoluções e Circulares referentes às alterações no regulamento das importações, bem como as que afetaram a Resolução $\mathrm{n}^{\circ} 63 / 67$, editadas pelo Banco Central do Brasil entre 1996 e 1999.
} 
impedindo a identificação de uma relação entre as importações financiadas de algodão em pluma e o diferencial entre as taxas de juros através dos métodos econométricos empregados no presente estudo serão abordados a seguir.

As vendas de algodão em pluma no mercado internacional são realizadas com grande antecedência. Assim, as importações brasileiras dessa fibra são contratadas bem antes da chegada da mercadoria. Esse prazo varia muito, dependendo do país de origem do produto e do porto de destino no Brasil. Contudo, pode-se afirmar que, regra geral, não é inferior a seis meses $^{37}$.

Desde a abertura comercial no Brasil, as importações de algodão em pluma têm tido diversas origens e portos de destino. Tal fato implica em diferentes prazos entre a contratação da importação (tomada de decisão) e a chegada da mercadoria no país (registro da importação). Por essa razão, a generalização desse prazo, estabelecendo uma ou mais defasagens da variável explicativa pode não ser suficiente para captar uma relação entre as importações financiadas de algodão em pluma e o diferencial entre as taxas de juros nos mercados interno e externo nas análises de regressão.

Além disso, a partir de abril de 1999, houve uma mudança no sistema de apuração das importações brasileiras, o qual trouxe uma dificuldade adicional para detectar o periodo que decorre entre a tomada de decisão de importar algodão em pluma (e a possibilidade de arbitrar as taxas de juros nos mercados interno e externo) e o registro das importações efetivadas.

Até o primeiro trimestre de 1999, os dados de comércio exterior divulgados pela Secretaria de Comércio Exterior (Secex) do Ministério do Desenvolvimento, Indústria e Comércio (MDIC) eram apurados pelo

\footnotetext{
${ }^{37}$ No caso dos países do MERCOSUL, esse prazo é bem menor.
} 
Sistema Geral, o qual considera o registro da Declaração de Importação (DI), emitida na chegada da mercadoria, como o registro estatístico das importações. A partir do mês de abril, as importações brasileiras passaram a ser apuradas sob o Sistema Especial, cujas estatísticas referem-se à liberação da mercadoria sob o controle aduaneiro, ou seja, depois do desembaraço.

Outro aspecto que pode estar fazendo com que as operações de arbitragem entre as taxas de juros interna e externa não sejam caracterizadas como um comportamento regular é a seletividade na concessão de crédito aos tomadores de empréstimos.

Lundberg et al. (1999) analisaram a composição do spread bancário e concluíram que a inadimplência é o custo que mais onera a diferença entre a taxa de juros com que o banco capta seus recursos e aquela que o tomador paga pelo crédito no Brasil. Na ausência de um ambiente macroeconômico favorável e previsivel, a baixa alavancagem em suas carteiras de crédito e o aumento da tomada de posições em títulos e valores mobiliários permite aos bancos protegerem-se numa conjuntura incerta.

Nesse contexto, as instituições financeiras atuam com grande seletividade na concessão de crédito, em função do elevado grau de inadimplência ${ }^{38}$. A avaliação do risco de crédito inclui um certo grau de arbitrariedade e o relacionamento da empresa junto ao banco é determinante na concessão de empréstimos. Por essa razão, o acesso aos mesmos no mercado interno é restrito e as taxas de juros cobradas diferem de acordo com a avaliação do risco de crédito pela instituições financeiras.

\footnotetext{
${ }^{38}$ Desde 1996, o risco de crédito assumido pelos bancos caiu bastante. Entretanto, no final de 1997, voltou a subir, devido às turbulências internas e internacionais presenciadas desde então (Lundberg et al., 1999).
} 
No caso das empresas brasileiras que importam algodão em pluma, a situação não é diferente. As instituições financeiras também atuam com grande seletividade na concessão de empréstimos para as diversas modalidades de crédito, no repasse dos recursos captados no exterior para aquisição da matéria-prima importada e na concessão de cartas de crédito. Além disso, as taxas praticadas variam de acordo com a operação, volume de crédito, prazos, garantias e tomadores diferenciados.

Nos anos de 1998 e 1999, as quatro maiores empresas no setor de fiação, tecelagem e confecção ${ }^{39}$ responderam, respectivamente, por cerca de $35 \%$ e $28 \%$ do volume total de algodão em pluma importado. Seguramente, são empresas que contam com acesso facilitado na obtenção de crédito e taxas de juros mais baixas nos mercados interno e externo. Entretanto, a maior parte do algodão importado está relacionado a empresas que enfrentam obstáculos na obtenção de financiamentos para realizar suas compras no exterior. Além disso, as taxas de juros cobradas nessas operações são superiores àquelas oferecidas às empresas de maior porte.

Assim, devido à seletividade na concessão de crédito pelas instituições financeiras, muitas empresas não têm acesso a recursos para financiar a aquisição do algodão importado. As taxas de juros cobradas nos empréstimos diferem de acordo com o tomador, visto que os bancos avaliam o risco de crédito e cobram um adicional proporcional ao mesmo, que varia de empresa para empresa.

Nesse contexto, as oportunidades de arbitragem entre as taxas de juros nos mercados interno e externo ficam restritas às empresas que têm acesso facilitado ao crédito interno e externo e, por conseguinte,

\footnotetext{
${ }^{39}$ Refere-se às quatro maiores empresas no setor de fiação, tecelagem e confecção, considerando-se a receita operacional líquida no ano de 1998 (Balanço Anual Nacional Gazeta Mercantil, 1999).
} 
obtém as menores taxas para financiar a aquisição do algodão em pluma no mercado internacional.

Uma vez que as oportunidades de arbitrar as taxas de juros nos mercados interno e externo estão relacionadas às conjunturas ditadas pelo ambiente macroeconômico e provavelmente estão restritas a algumas empresas, não foi factivel identificar o vinculo entre as importações financiadas de algodão em pluma e a arbitragem entre as taxas de juros nos mercados interno e externo, através das análises econométricas empregadas neste estudo.

Apesar desses resultados, parece razoável admitir que enquanto persistirem as condições de taxas de juros inferiores às vigentes no mercado interno e prazos de pagamento dilatados, deverá haver algodão sendo importado, exceto se o preço doméstico cair significativamente abaixo da paridade internacional, como forma de compensar a vantagem financeira nas importações.

As aquisições de algodão em pluma no mercado externo reduzem as possibilidades de hedging do produto importado no Brasil porque o mercado futuro de algodão em pluma da BM\&F reflete as condiçōes de oferta e demanda domésticas. Então, o contrato futuro dessa Bolsa não seria eficaz para administrar o risco de preço da fibra importada. Analogamente, o contrato futuro da $\mathrm{NYCE}$ reflete as condições do mercado norte americano, não sendo eficiente para o hedge de preço do algodão proveniente de outros paises. 


\subsection{Resultados da análise de co-integração entre os preços do algodão em pluma nos mercados interno e externo}

\subsubsection{Resultados da determinação da ordem de integração das séries de preços}

Para verificar se os preços do algodão em pluma no Brasil e no mercado internacional movem-se conjuntamente no longo prazo, foram realizados testes de raiz unitária nas séries e, posteriormente, procedeuse à análise de co-integração entre o preço do algodão no Brasil e o Cotlook A Index. Foram utilizados dados mensais e o periodo analisado foi de janeiro de 1988 a dezembro de 1999. O número de observações em cada série foi 144 .

Inicialmente, procedeu-se a verificação da ordem de integração da série de preços do algodão em pluma no Brasil, representado pelo preço no atacado em São Paulo e da série de preços do algodão em pluma no mercado internacional, representado pelo Cotlook A Index.

Para identificar a ordem dos processos autorregressivos dessas séries de preços foram utilizados o AIC e o SC, cujos resultados são apresentados no Apêndice 7 . Os valores obtidos indicam que a série de preço do algodão em pluma no Brasil é descrita por um processo autorregressivo de ordem cinco $[\mathrm{AR}(5)]$, enquanto a série do Cotlook $A$ Index é descrita por um processo $\mathrm{AR}(2)$.

Após a identificação dos processos autorregressivos, seguiu-se a verificação da ordem de integração das séries de preços, através dos testes de DFA. O procedimento seqüencial apresentado no Apêndice 1 foi utilizado para verificar a significância dos elementos determinísticos e a existência de raiz unitária nas séries. 
$\mathrm{Na}$ realização dos testes seqüenciais, estabeleceu-se o nível de significância de 1\% para as estatísticas de DF. Acima desse nivel de probabilidade, os valores testados foram considerados estatisticamente significativos. Esse procedimento foi adotado porque, para niveis de significância maiores, as séries apresentaram-se estacionárias em nível. Entretanto, existem razões consistentes para acreditar que as séries em nível contém uma raiz unitária.

Primeiramente, a análise das funções de auto correlação (fac) indica a presença de raiz unitária nas duas séries de preços em nivel, o que não ocorre para as séries nas primeiras diferenças. Os correlogramas das fac para as séries de preço do algodão em pluma no Brasil e Cotlook A Index são apresentados no Apêndice 8. Além disso, através da análise gráfica da Figura 1, nota-se que as médias das séries de preços do algodão em pluma nos mercados doméstico e internacional parecem não ser constantes, indicando que as séries não são estacionárias.

Tendo em vista as razões apontadas acima, considerou-se prudente tomar as séries como I(1). Os resultados do procedimento seqüencial para testar a significância dos elementos determinísticos e a presença de raiz unitária nas séries de preço no Brasil e na série do Cotlook A Index encontram-se na Tabela 12.

Nota-se através da referida Tabela que, ao nivel de probabilidade de $1 \%$, os valores referentes às estatísticas $\tau_{\tau}, \tau_{\beta \tau}, \phi_{3}, \tau_{\mu}, \tau_{\alpha \mu}$ e $\phi_{1}$ são não significativos. Esses resultados indicam que os componentes determinísticos tendência e constante não devem ser incluídos nos modelos utilizados para testar a presença de raiz unitária nas séries de preços. A estatística apropriada para o teste de DFA em modelos que não incluem elementos determinísticos é a $\tau$, cujos resultados estão na última linha da Tabela 12. 
Tabela 12. Resultados da identificação dos elementos determinísticos e testes de raiz unitária nas séries de preço do algodão em pluma nos mercados interno e externo.

\begin{tabular}{ccc} 
& \multicolumn{2}{c}{ Séries em nivel } \\
\hline \multirow{2}{*}{ Estatistica } & $\begin{array}{c}\text { Preço do algodão no } \\
\text { Brasil }\end{array}$ & Cotlook A Index \\
\hline$\tau_{\tau}$ & $\mathrm{t}=-3,91$ & $\mathrm{t}=-3,50$ \\
$\tau_{\beta \tau}$ & $\mathrm{t}=2,40$ & $\mathrm{t}=1,94$ \\
$\phi_{3}$ & $\mathrm{~F}=7,66$ & $\mathrm{~F}=6,15$ \\
$\tau_{\mu}$ & $\mathrm{t}=-3,04$ & $\mathrm{t}=-2,89$ \\
$\tau_{\alpha \mu}$ & $\mathrm{t}=3,05$ & $\mathrm{t}=2,90$ \\
$\phi_{1}$ & $\mathrm{~F}=4,75$ & $\mathrm{~F}=4,20$ \\
$\tau$ & $\mathbf{t}=\mathbf{0 , 4 1}$ & $\mathbf{t}=\mathbf{0 , 0 1 5}$
\end{tabular}

Notas: os valores criticos das estatísticas DF são apresentados em Fuller (1996) e Dickey \& Fuller (1981). O tamanho da amostra utilizada para realização dos testes foi 250 e o nivel de significância adotado foi $1 \%$.

Os valores relativos à estatística $\tau$ apresentaram-se não significativos estatisticamente. A não rejeição da hipótese nula indica a presença de raiz unitária nas duas séries de preços. Assim, seguiram-se os testes de raiz unitária para as séries na primeira diferença.

A Tabela 13 mostra os resultados dos testes de raiz unitária para as séries na primeira diferença. Os valores dos testes apresentaram-se significativos para as duas séries de preços. A rejeição da hipótese nula implica que as mesmas são estacionárias na primeira diferença. Portanto, pode-se inferir que a série de preços do algodão em pluma no Brasil e a série do Índice Cotlook $A$ são integradas de ordem um, isto é, I(1). 
Tabela 13. Resultados dos testes de raiz unitária para as séries de preço do algodão em pluma (na primeira diferença) nos mercados interno e externo.

Séries na $1^{a}$ diferença

\begin{tabular}{cccc}
\hline Estatistica & $\begin{array}{c}\text { Valor critico } \\
(\mathbf{1 \% )})\end{array}$ & $\begin{array}{c}\text { Preço do algodão em pluma no } \\
\text { Brasil }\end{array}$ & Cotlook A Index \\
\hline$\tau$ & $-2,58$ & $\mathrm{t}=-6,52^{*}$ & $\mathrm{t}=-6,65^{\star}$
\end{tabular}

Notas: os valores criticos para a estatistica $\tau$ encontram-se em Fuller (1996); * valor significativo a $1 \%$; o tamanho da amostra utilizada para realização do teste foi 250 .

\subsubsection{Resultados da estimativa da relação de equilibrio de longo prazo}

Depois de verificar que as duas séries de preços são I(1), a primeira etapa para testar co-integração, consiste em estimar a relação de equilibrio de longo prazo por Mínimos Quadrados Ordinários (MQO) e testar a estacionariedade dos resíduos da regressão.

A relação de longo prazo entre o preço do algodão em pluma no Brasil e o Cotlook $A$ Index foi estimada na forma da equação (29):

$$
L S P_{t}=\beta_{0}+\beta_{1} L I A_{t}+e_{a t}
$$

onde:

$L S P_{t}=$ logarítmo do preço do algodão em pluma no atacado em São Paulo no momento t;

$\beta_{0}=$ constante;

$\beta_{1}=$ coeficiente que representa a elasticidade de transmissão de preço no longo prazo;

$L I A_{t}=\operatorname{logaritmo}$ do Cotlook $A$ Index no momento t;

$e_{a t}=$ termo de erro. 
Os resultados da estimativa da relação de longo prazo, representada pela equação (29) são apresentados na Tabela 14. Se as variáveis $L S P$ e $L I A$ forem co-integradas, o método de MQO resulta em estimadores "super consistentes" dos parâmetros da relação de longo prazo.

Tabela 14. Resultados da estimativa da relação de longo prazo entre o preço do algodão em pluma no Brasil e o Cotlook A Index.

\begin{tabular}{cc}
\cline { 2 - 2 } & \multicolumn{2}{c}{ Relação de longo prazo } \\
\cline { 2 - 2 } & Preço no Brasil e Cotlook $\boldsymbol{A}$ \\
\hline Análise de Regressão & $\mathrm{F}=114,49^{\star}$ \\
\hline Variáveis & Coeficientes \\
Constante & $1,94^{\star}(9,19)$ \\
$L I A_{t}$ & $0,5315^{\star}(10,70)$ \\
\hline
\end{tabular}

Notas: os valores da estatística $t$ encontram-se entre
parênteses; * significativo a $1 \%$.

Para verificar se as variáveis são co-integradas, testa-se a estacionariedade dos resíduos estimados na relação de longo prazo. Com tal finalidade, foi estimada a equação (30):

$$
\Delta \hat{e}_{a t}=h_{1} \hat{e}_{a t-1}+h_{2} \Delta \hat{e}_{a t-1}+u_{t}
$$

sendo:

$\Delta \hat{e}_{a t}=$ estimativa dos resíduos da equação (29) na primeira diferença, no momento t;

$\hat{e}_{a t-1}=$ estimativa dos resíduos da equação (29),no momento t-1;

$\Delta \hat{e}_{a t-1}=$ estimativa dos resíduos da equação (29) na primeira diferença, no momento t-1; $u_{t}=$ ruído branco. 
A variável na primeira diferença defasada de um periodo foi incluída na equação (30), a fim de eliminar a autocorrelação serial e proceder-se o teste de DFA para verificar a presença de raiz unitária. Entretanto, os resíduos da relação de longo prazo são estimativas dos verdadeiros erros, razão pela qual não é possivel utilizar as tabelas construídas por Dickey \& Fuller. O valor utilizado para testar a hipótese nula de que o parâmetro $h_{1}$ é igual a zero é fornecido por Engle $\&_{6}$ Yoo (1987).

Os resultados do teste para verificar a estacionariedade dos resíduos estimados na relação de longo prazo podem ser observados na Tabela 15. O teste apresentou-se significativo a $1 \%$, indicando que, à esse nivel de probabilidade, rejeita-se a hipótese nula de que $h_{1}$ [pertencente ao intervalo $(-2,0)$ ] seja igual a zero.

Tabela 15. Resultado do teste para verificar a estacionariedade dos resíduos estimados na relação de longo prazo.

\begin{tabular}{cccc}
\hline Valor critico & Hipótese & Coeficiente & Valor de t \\
\hline 4,00 & $h_{1}=0$ & $h_{1}=-0,36$ & $\mathrm{t}=-5,63^{*}$ \\
\hline
\end{tabular}

Notas: valor crítico obtido em Engle \& Yoo (1987); * significativo a 1\%; o tamanho da amostra utilizado no teste foi 200 .

A rejeição da hipótese nula indica que a seqüência eat é estacionária e que, portanto, as variáveis $L S P$ e $L I A$ são co-integradas de ordem $\mathrm{CI}(1,1)$. Por essa razão, pode-se afirmar que existe uma relação de longo prazo entre o preço do algodão em pluma no Brasil e o Cotlook A Index.

Assim, os parâmetros estimados na relação de longo prazo entre o Cotlook A Index e o preço do algodão em pluma no atacado em São Paulo são consistentes. Os resultados daquela relação (Tabela 14) 
indicam que, $53 \%$ de uma variação no Cotlook A Index é transmitida para o preço do algodão em pluma em São Paulo no longo prazo.

A existência de uma relação de longo prazo entre esses preços ao longo da década de noventa reflete algumas mudanças ocorridas no período. Primeiramente, a liberalização comercial do setor cotonícola tanto no âmbito nacional, pela alteração do papel do governo em diversos países produtores em desenvolvimento, como no internacional, através do processo de abertura econômica, a exemplo do Brasil. Em segundo lugar, a melhoria na tecnologia da informação, que tem tornando muito mais fácil a disseminação das informações sobre as condições de oferta e demanda através dos mercados (Baffes \& Ajwad, 1998).

\subsubsection{Resultados da estimativa do Modelo de Correção de Erro (MCE)}

Se as variáveis são co-integradas, é possivel utilizar os resíduos da regressão de equilibrio de longo prazo para estimar o Modelo de Correção de Erro (MCE). Essa é a segunda etapa do procedimento proposto por Engle \& Granger (1987) para testar co-integração entre variáveis.

Para estimar o Modelo de Correção de Erro (MCE), conforme descrito pela equação (26), é necessário determinar o número de defasagens das variáveis dependente e explicativa na primeira diferença, a serem incluídas no modelo.

No caso da variável $L S P$, o número de defasagens de $\triangle L S P$ a ser incluído no MCE foi determinado através da análise da função de autocorrelação dos resíduos de uma autorregressão ${ }^{40}$ dessa variável. Considerando-se as variáveis explicativas, o número de defasagens de

\footnotetext{
${ }^{40}$ Os resultados do AIC e SC para determinação da ordem do processo autorregressivo da série de preço do algodão em pluma no atacado em São Paulo, estão no Apêndice 7, conforme descrito na Seção 8.3.1.
} 
$\triangle L I A$ a ser incluído no modelo foi determinado através da função de correlação cruzada entre $\triangle L S P$ e $\triangle L I A$.

Assim, o MCE para as variáveis $L S P$ e $L I A$ é representado pela equação (31):

$$
\begin{aligned}
& \Delta L S P_{t}=a_{L S P} \hat{e}_{a t-1}+b_{0} \Delta L I A_{t}+b_{1} \Delta L I A_{t-1}+b_{2} \Delta L I A_{t-2}+ \\
& +b_{3} \Delta L I A_{t-3}+b_{4} \Delta L I A_{t-4}+b_{5} \Delta L I A_{t-5}+b_{6} \Delta L I A_{t-6}+b_{7} \Delta L I A_{t-7}+ \\
& +b_{8} \Delta L I A_{t-8}+b_{9} \Delta L I A_{t-9}+b_{10} \Delta L I A_{t-10}+c_{1} \Delta L S P_{t-1}+c_{2} \Delta L S P_{t-2}+ \\
& +c_{3} \Delta L S P_{t-3}+c_{4} \Delta L S P_{t-4}+c_{5} \Delta L S P_{t-5}+c_{6} \Delta L S P_{t-6}+u_{t}
\end{aligned}
$$

$a_{L S P}=$ coeficiente de correção de erro ou velocidade de ajustamento;

$\Delta L S P_{t}=$ logarítmo do preço do algodão em pluma no atacado em São Paulo na primeira diferença, no momento $t$;

$\Delta L I A_{t-i}=\operatorname{logaritmo}$ do Cotlook $A$ Index na primeira diferença no momento $t-i ; \mathrm{i}=1$ até 10 ;

$\Delta L S P_{t-i}=$ logarítmo do preço do algodão em pluma no atacado em São Paulo na primeira diferença, no momento $t-i ; i=1$ até 6 ;

$u_{t}=$ ruido branco.

Os resultados da estimativa do $\mathrm{MCE}$ representado pela equação (31) são apresentados na Tabela 16. Verificou-se, através da estatística $\mathrm{Q}$ de Ljung Box, que os resíduos do modelo estimado apresentaram-se não correlacionados. 
Tabela 16. Resultado da estimativa do MCE para as variáveis preço do algodão em pluma no Brasil e Cotlook $A$ Index.

\begin{tabular}{ccc}
\hline Variável & Valor do coeficiente & Valor de t \\
\hline$\alpha L S P^{*}$ & $-0,41^{*}$ & $-3,92$ \\
$\Delta L I A_{t}$ & 0,084 & 0,53 \\
$\Delta L I A_{t-1}$ & 0,054 & 0,29 \\
$\Delta L I A_{t-2}$ & $-0,0043$ & $-0,022$ \\
$\Delta L I A_{t-3}$ & $-0,072$ & $-0,39$ \\
$\Delta L I A_{t-4}$ & 0,079 & 0,44 \\
$\Delta L I A_{t-5}$ & $-0,38^{* *}$ & $-2,066$ \\
$\Delta L I A_{t-6}$ & 0,0054 & 0,029 \\
$\Delta L I A_{t-7}$ & 0,19 & 1,048 \\
$\Delta L I A_{t-8}$ & 0,17 & 0,95 \\
$\Delta L I A_{t-9}$ & $-0,23$ & $-1,26$ \\
$\Delta L I A_{t-10}$ & $0,39^{* *}$ & 2,45 \\
$\Delta L S P_{t-1}$ & $0,25^{* *}$ & 2,29 \\
$\Delta L S P_{t-2}$ & 0,061 & 0,58 \\
$\Delta L S P_{t-3}$ & $-0,0087$ & $-0,084$ \\
$\Delta L S P_{t-4}$ & $0,20^{* *}$ & 2,10 \\
$\Delta L S P_{t-5}$ & 0,13 & 1,38 \\
$\Delta L S P_{t-6}$ & $-0,078$ & $-0,88$
\end{tabular}

Notas: * significativo a $1 \%$; ${ }^{* *}$ significativo a $5 \%$.

Pode-se observar através da Tabela 16 que o valor do coeficiente da velocidade de ajustamento é estatisticamente diferente de zero, confirmando que as variáveis LSP e LIA são co-integradas. Quanto aos coeficientes das variáveis $\Delta L S P_{t-i}$, eles indicam a taxa de crescimento da variação do preço do algodão em pluma no atacado em São Paulo no momento t, que será transmitida após $i$ periodos. Nota-se que apenas os coeficientes $c_{1}$ e $c_{4}$ apresentaram-se estatisticamente significativos, indicando que a transmissão de preços no mercado interno ocorre no primeiro e quarto meses após uma dada variação. 
Já os coeficientes das variáveis $\Delta L I A_{t-i}$ indicam a taxa de crescimento à qual a variação do Cotlook $A$ Index será transmitida para o preço do algodão em pluma no atacado em São Paulo, após $i$ períodos. Entretanto, apenas os coeficientes $b_{5}$ e $b_{10}$ são estatisticamente diferentes de zero. Tal resultado indica que as variações de preço do mercado internacional para o doméstico ocorrem após um periodo de cinco meses (no sentido inverso) e após dez meses (no mesmo sentido).

Esses intervalos de tempo são bastante longos e estariam indicando que haveria um certo descolamento contemporâneo entre os movimentos dos preços nos mercados interno e externo, refletindo apenas as condições de oferta e demanda domésticas e não as variações no mercado internacional.

Apesar da liberalização comercial ocorrida durante a década de noventa, em parte, essa situação pode ser explicada pelas políticas governamentais de suporte de preço no Brasil e também pelo tipo de algodão produzido, que pode diferir relativamente aos tipos cotados no mercado internacional. Essas condições poderiam estar levando o mercado do algodão em pluma no Brasil a ser regionalizado no curtíssimo prazo.

Entretanto, a melhoria na tecnologia da informação tem facilitado a disseminação das informações sobre as condições de demanda entre os mercados, fato conflitante com os resultados obtidos. Assim, o MCE pode estar captando alguma relação de origem espúria entre as variáveis utilizadas no estudo. A explicação para os resultados obtidos requer uma investigação mais profunda sobre as relações de preços do algodão em pluma nos mercados interno e externo, algo que foge do escopo do presente estudo. 


\section{CONCLUSŌES}

O presente estudo teve por objetivo analisar alguns fatores que podem estar afetando o potencial de desenvolvimento do mercado futuro do algodão em pluma no Brasil, visto que o mesmo tem apresentado baixíssima liquidez desde o seu relançamento pela Bolsa de Mercadorias \& Futuros, em 1996.

Através dos resultados obtidos nas estimativas das razões ótimas e efetividade de hedge, pode-se concluir que, apesar de a redução do risco de preço não ter sido elevada e da baixa liquidez do mercado futuro de algodão no Brasil, o contrato da BM\&F tem sido eficaz na transferência do risco de preço para o produto brasileiro. O mesmo não pode ser dito em relação ao contrato futuro de algodão em pluma da NYCE.

Esses resultados permitem concluir que o potencial de desenvolvimento do mercado futuro de algodão no Brasil não deve ser afetado pela possibilidade de realizar o hedge de preço do algodão brasileiro na NYCE, visto que essa operação não é efetiva em termos de redução do risco de preço para o produto nacional. Além disso, o desenvolvimento de um mercado futuro de algodão no Brasil é importante porque pode tornar-se uma referência para os países do MERCOSUL.

Adicionalmente, procurou-se analisar a vinculação entre as importações financiadas de algodão em pluma e a arbitragem entre as taxas de juros nos mercados interno e externo. Entretanto, não foi 
possivel detectar, através dos métodos econométricos empregados, a relação entre essas variáveis. Possivelmente, tal fato esteja relacionado à prática dessas operações em situações conjunturais específicas, não sendo factível a identificação de um comportamento sistemático ao longo do período analisado.

Existe ainda a possibilidade de as importações financiadas ocorrerem primordialmente em função dos prazos de pagamento oferecidos no mercado internacional e não da diferença entre as taxas de juros interna e externa, pois as compras de algodão em pluma no mercado doméstico são pagas à vista. Nesse caso, pode-se concluir que nenhuma relação entre o diferencial das taxas de juros e as importações financiadas seria encontrada.

Apesar dos resultados obtidos, a possibilidade de adquirir o produto importado a preços competitivos e prazos dilatados de pagamento no mercado internacional e ainda obter ganhos financeiros com a operação (ainda que restritos às oportunidades conjunturais interna e externa) pode estar fazendo com que os compradores de matéria-prima importada deixem de se preocupar com a administração do risco de preço. Tal situação estaria afetando negativamente o potencial de desenvolvimento do mercado futuro de algodão no Brasil.

Contudo, a mudança no regime cambial implementada em janeiro de 1999 tornou as importações financiadas de algodão em pluma menos vantajosas. Esse aspecto pode incentivar o aumento da produção nacional e exercer impactos positivos no desenvolvimento do mercado futuro de algodão no Brasil. Basta lembrar que, historicamente, o desenvolvimento desse mercado no paîs esteve ligado à expansão da cotonicultura nacional.

Ademais, destaca-se que a produção nacional de algodão está crescendo acentuadamente, em função da reestruturação produtiva dos 
últimos anos. O abastecimento auto-suficiente do mercado doméstico afeta favoravelmente o desenvolvimento do mercado futuro de algodão em pluma no Brasil, visto que o contrato da BM\&F tem sido efetivo na redução do risco de preço para o produto brasileiro.

Nesse contexto, a existência de um mercado à termo nas novas regiōes cotonícolas, pode contribuir para o desenvolvimento do mercado futuro de algodão no país, uma vez que os agentes que adquirem a matéria-prima antecipadamente podem administrar o risco de preço do produto nacional através do contrato futuro de algodão em pluma da $\mathrm{BM} \& \mathrm{~F}$.

Não obstante, ressalta-se que muitas empresas sequer realizam o hedge cambial do produto importado, denotando uma certa despreocupação com a gestão do risco de preço, considerando que os prazos de financiamento das importações chegam a ser superiores a 360 dias. Assim, pode-se afirmar que a própria estrutura de comercialização ainda não estaria preparada para atuar nesses mercados, que exigem estratégias relativamente mais sofisticadas e, por conseguinte, pessoal qualificado para desempenhar essas atividades.

Através dos resultados dos testes de co-integração entre os preços do algodão nos mercados interno e externo, pode-se concluir que os mesmos apresentam uma relação de longo prazo. Essa relação parece indicar que a formação dos preços domésticos não é exclusivamente interna. Contudo, a estimativa da relação de curto prazo através do Modelo de Correção de Erro não levou a resultados conclusivos, mas parece indicar que os movimentos dos preços no mercado internacional não são transmitidos contemporaneamente para os preços domésticos.

Esse possivel comportamento, o qual reflete um certo descolamento contemporâneo entre os preços doméstico e internacional no curtíssimo prazo, pode estar relacionado às intervençōes do governo 
na comercialização do algodão no Brasil. Entretanto, tais resultados devem ser tomados como indicativos, uma vez que é necessária uma análise mais profunda para que se possa explicar essa relação de preço no curto prazo. Em todo caso, ressalte-se que o governo, ao reduzir a incerteza através da garantia de preços ou ao aumentá-la através de açōes que modificam constantemente as caracteristicas do mercado, afeta negativamente o potencial de desenvolvimento do mercado futuro de algodão no Brasil.

Finalmente, destaca-se a importância da participação de todos os agentes para o desenvolvimento do mercado, pois um contrato futuro só será bem sucedido se for usado para hedging (Working, 1953). Entretanto, somente a participação dos hedgers não garante o desenvolvimento de um mercado futuro. Os especuladores são fundamentais para dar liquidez ao mercado futuro, absorvendo o excesso de oferta ou demanda de contratos, que podem criar grandes distorçōes de preços.

A ausência de especulação pode resultar em elevados custos de hedging, reduzindo o volume de operações e levando à falência de um contrato. Na fase inicial de criação de um contrato, a possibilidade de não conseguir sair do mercado até o vencimento pode culminar com a entrega ou recebimento da mercadoria, afastando especuladores e investidores institucionais e reduzindo a liquidez do mercado.

Em tal contexto, deve-se salientar uma possível conseqüência da alteração na forma de liquidação do contrato futuro de algodão em pluma efetuada pela BM\&F em março de 1999. Até então, os contratos eram liquidados financeiramente pelo Indipluma ESALQ/BM\&F. Todavia, como parte da estratégia de internacionalização daquela instituição, os contratos passaram a ser liquidados por entrega fisica. 
Essa modificação parece ter levado a volumes muito baixos a liquidez no mercado futuro de algodão em pluma, uma vez que o número de contratos em aberto vinha crescendo de forma consistente, embora à taxas baixas, até a modificação introduzida em março de1999.

Além da ausência de especuladores, a falta de grandes empresas traders de algodão em pluma na estrutura de comercialização pode estar afetando a liquidez do mercado futuro desse produto. Esses agentes são importantes para dar liquidez ao mercado futuro porque atuam nas pontas compradora e vendedora do produto.

As conclusões gerais do presente estudo são de que o potencial do mercado futuro de algodão em pluma no Brasil ainda não foi efetivado, considerando as dificuldades conjunturais que o mesmo tem enfrentado para se desenvolver. Os resultados obtidos demonstram que o contrato futuro da $B M \& F$ tem sido um instrumento efetivo de administração do risco de preço do produto brasileiro, apesar da baixissima liquidez desse mercado e de a redução do risco de preço não ser elevada.

No entanto, a questão da não utilização do contrato futuro de algodão em pluma no Brasil é bastante complexa e não poderia ser esgotada no escopo deste estudo. A necessidade de pesquisas sobre o tema é de suma importância para a efetivação do potencial desse mercado. Embora venha passando por dificuldades conjunturais, esse mercado tem potencial para se desenvolver, considerando-se que é uma alternativa efetiva para a administração do risco de preço do produto brasileiro. 


\section{ANEXOS}


Para as importações financiadas até 180 dias, o melhor ajustamento ocorreu com modelo incluindo variáveis binárias anuais, conforme descrito pela equação a seguir:

$$
\begin{aligned}
& I M P 180_{t}=a+b_{3} \text { dummy3 }+b_{4} \text { dummy } 4+b_{5} \text { dummy } 5+ \\
& +d_{j_{t-i}}(F C G o u C D B)+I M P 180_{t-1}+I M P 180_{t-2}+e_{t}
\end{aligned}
$$

IMP180 1 importações financiadas até 180 dias no momento t;

dummy3, dummy4 e dummy5 = variáveis binárias, que assumem o valor um para os anos de 1997, 1998 e 1999, respectivamente, e zero para os demais;

$d_{j}$ t-i $(F C G$ ou CDB $)=$ diferença entre o custo do financiamento do capital de giro (FCG) ou CDB e o custo de captação de recursos externos, no momento t-i; $\mathrm{i}=6$ a 12 em cada modelo. Quando $\mathrm{j}=1$, refere-se ao FCG ou $\mathrm{CDB}$, descontando-se a variação cambial $\left(\mathrm{d}_{1}\right)$ e quando $\mathrm{j}=2$, corresponde ao custo efetivo real do FCG ou CDB $\left(\mathrm{d}_{2}\right)$.

IMP180 $\mathrm{t}_{-1}=$ importações financiadas até 180 dias no momento $\mathrm{t}-1$;

IMP180 $\mathrm{t}-2_{2}=$ importações financiadas até 180 dias no momento $\mathrm{t}-2$;

$\mathrm{e}_{\mathrm{t}}=$ ruído branco.

Assim sendo, foram estimadas 28 regressões, uma correspondente a cada diferencial entre as taxas de juros nos mercados interno e externo ( $d_{1}$ para o $C D B, d_{1}$ para o $F C G, d_{2}$ para o CDB e $d_{2}$ para o $F C G$ ), nas defasagens sucessivas de 6 até 12 períodos. Os resultados das regressões estimadas conforme a equação acima encontram-se nas Tabelas A1 e A2. 
Tabela A1. Resultados das regressões entre as importações financiadas até 180 dias e os diferenciais entre as taxas de juros nos mercados interno e externo $\left(\mathrm{d}_{1}\right)$, considerando-se o FCG e o CDB.

\begin{tabular}{|c|c|c|c|c|c|c|c|c|}
\hline \multicolumn{2}{|c|}{$\begin{array}{c}\text { Análises de } \\
\text { regressão }\end{array}$} & \multicolumn{7}{|c|}{ Coeficientes das variáveis das regressōes } \\
\hline $\mathrm{F}$ & $\overline{\mathrm{R}^{2}}$ & $\mathrm{~d}_{1 \mathrm{t} \cdot 6}(\mathrm{FCG})$ & Constante & dummy3 & dummy 4 & dummy5 & IMP180t-1 & IMP180t-2 \\
\hline $8,44^{\star}$ & 0,52 & 0,070 & $16,35^{\star}$ & $-5,67^{\star \star \star}$ & $-12,03^{\star}$ & $-6,01^{\star}$ & $0,55^{\star}$ & $-0,19$ \\
\hline $\mathrm{F}$ & $\overline{\mathrm{R}^{2}}$ & $\mathrm{~d}_{1 \mathrm{t} .7}(\mathrm{FCG})$ & Constante & dummy3 & dummy 4 & dummy5 & IMP180t. 1 & IMP180t-2 \\
\hline $9,34^{*}$ & 0,56 & 0,031 & $21,57^{\star}$ & $-7,87^{\star \star}$ & $-14,79^{\star}$ & $-9,11^{*}$ & $0,51^{*}$ & $-0,24$ \\
\hline $\mathrm{F}$ & $\overline{\mathrm{R}^{2}}$ & $\mathrm{~d}_{1 \mathrm{t}-8}(\mathrm{FCG})$ & Constante & dummy3 & dummy 4 & dummy5 & IMP180t-1 & IMP180t-2 \\
\hline $10,76^{\star}$ & 0,60 & 0,063 & $25,90^{*}$ & $-10,64^{\star}$ & $-18,94^{\star}$ & $-12,39^{\star}$ & $0,44^{\star}$ & $-0,28^{\star \star \star \star}$ \\
\hline $\mathrm{F}$ & $\mathrm{R}^{2}$ & $\mathrm{~d}_{1 \mathrm{t} .9}(\mathrm{FCG})$ & Constante & dummy3 & dummy 4 & dummy5 & $\mathrm{IMP180} t-1$ & IMP180t-2 \\
\hline $10,53^{\star}$ & 0,60 & 0,046 & $30,89^{\star}$ & $-13,49^{\star}$ & $-22,37^{\star}$ & $-15,73^{\star}$ & $0,39^{\star \star}$ & $-0,30^{\star \star}$ \\
\hline $\mathrm{F}$ & $\overline{\mathrm{R}^{2}}$ & $\mathrm{~d}_{1 \mathrm{t} \cdot 10}(\mathrm{FCG})$ & Constante & dummy3 & dummy4 & dummy5 & IMP180t 1 & IMP180t-2 \\
\hline $7,88^{\star}$ & $0, \overline{53}$ & $0, \overline{057}$ & $20,38^{\star}$ & $-6,71$ & $-13,92^{\star \star}$ & $-8,27$ & $0,44^{\star}$ & $-0,20$ \\
\hline$F$ & $\overline{R^{2}}$ & $\mathrm{~d}_{1 \mathrm{t}-11}(\mathrm{FCG})$ & Constante & dummy3 & dummy4 & dummy5 & IMP180t-1 & IMP180t-2 \\
\hline $7,16^{\star}$ & $0, \overline{51}$ & 0,0074 & $28,72^{\star}$ & $-13,41^{\star \star}$ & $-20,64^{*}$ & $-15,25^{\star \star}$ & $0, \overline{57^{\star}}$ & $-0,34^{\star \star}$ \\
\hline$F$ & $\mathrm{R}^{2}$ & $\mathrm{~d}_{1 \mathrm{t}-12}(\mathrm{FCG})$ & Constante & dummy3 & dummy4 & . & IMP180t 1 & IMP180 18 \\
\hline $6,96^{\star}$ & $0, \overline{46}$ & $-0,079$ & $16,49^{\star}$ & 0,84 & $-6,01^{\star \star}$ & & $0, \overline{58^{\star}}$ & $-0,35^{\star \star}$ \\
\hline F & $\mathrm{R}^{2}$ & $\mathrm{~d}_{1 \mathrm{t} \cdot \sigma}(\mathrm{CDB})$ & Constante & dummy 3 & dummy 4 & dummy5 & IMP180t 1 & $\mathrm{IMP} 180_{\mathrm{t}-2}$ \\
\hline $8,15^{\star}$ & 0,51 & $0, \overline{020}$ & $17,99^{\star}$ & $-5,61^{\star \star \star}$ & $-11,29^{\star}$ & $-6,25^{\star \star \star}$ & $0,57^{\star}$ & $-0,21$ \\
\hline $\mathrm{F}$ & $\overline{R^{2}}$ & $\mathrm{~d}_{1 \mathrm{t}-7}(\mathrm{CDB})$ & Constante & dummy3 & dummy 4 & dummy5 & IMP180t-1 & IMP180t. 2 \\
\hline $9,36^{*}$ & 0,56 & $0,04 \overline{41}$ & $22,2^{\star}$ & $-7,88^{\star \star}$ & $-14,53^{\star}$ & $-8,7^{\star \star}$ & $0,51^{\star}$ & $-0,24$ \\
\hline $\mathrm{F}$ & $\bar{R}^{2}$ & $\mathrm{~d}_{1 \mathrm{t}-8}(\mathrm{CDB})$ & Constante & dummy3 & dummy4 & dummy5 & IMP180 18 & IMP180t-2 \\
\hline $10,74^{\star}$ & 0,60 & 0,076 & $27,16^{\star}$ & $-10,69^{\star}$ & $-18,44^{\star}$ & $-11,69^{\star}$ & $0, \overline{44^{\star}}$ & $-0,26^{\star \star \star}$ \\
\hline F & $\overline{\mathrm{R}}^{2}$ & $d_{1 t} \cdot(C D B)$ & Constante & dummy3 & dummy 4 & dummy5 & IMP180t-1 & IMP180 18 \\
\hline $10,48^{\star}$ & $0, \overline{60}$ & 0,053 & $31,74^{\star}$ & $-13,33^{\star}$ & $-21,96^{\star}$ & $-15,12^{\star}$ & $0,39^{\star \star}$ & $-0,30 * \star$ \\
\hline$F$ & $\overline{\mathrm{R}}^{2}$ & $\mathrm{~d}_{1 \mathrm{t}} \cdot \mathrm{id}(\mathrm{CDB})$ & Constante & dummy3 & dummy4 & dummy5 & $\mathrm{IMP180} t-1$ & IMP180t-2 \\
\hline $7,89^{\star}$ & 0,53 & 0,078 & $21,72^{\star}$ & $-6,67$ & $-13,70^{\star \star}$ & $-7,57$ & $0,44^{*}$ & $-0,20$ \\
\hline $\mathrm{F}$ & $\overline{\mathrm{R}}^{2}$ & $d_{1 t-11}(C D B)$ & Constante & dummy3 & dummy4 & dummy5 & IMP180t 1 & $\mathrm{IMP} 180_{\mathrm{t} \cdot 2}$ \\
\hline $7,19^{\star}$ & 0,51 & 0,032 & $28,97^{*}$ & $-13,45^{\star \star}$ & $-20,72^{\star}$ & $-15,14^{\star \star}$ & $0,57^{\star}$ & $-0,34^{\star \star}$ \\
\hline $\mathrm{F}$ & $\overline{\mathrm{R}}^{2}$ & $\mathrm{~d}_{1 \mathrm{t}-12}(\mathrm{CDB})$ & Constante & dummy3 & dummy 4 & & IMP180t-1 & IMP180t-2 \\
\hline $6,84^{\star}$ & 0,46 & $-0,086$ & $13,79^{\star}$ & 1,71 & $-5,33^{\star \star}$ & & $0,58^{\star}$ & $-0,35^{\star \star}$ \\
\hline
\end{tabular}

Notas: ${ }^{*}$ significativo a $1 \%$; $^{* *}$ significativo a $5 \%$; ${ }^{\star \star \star}$ significativo a $10 \%$. 
Tabela A2. Resultados das regressões entre as importações financiadas até 180 dias e os diferenciais entre as taxas de juros nos mercados interno e externo $\left(\mathrm{d}_{2}\right)$, considerando-se o FCG e o CDB.

\begin{tabular}{|c|c|c|c|c|c|c|c|c|}
\hline \multicolumn{2}{|c|}{$\begin{array}{l}\text { Análises de } \\
\text { regressão }\end{array}$} & \multicolumn{7}{|c|}{ Coeficientes das variáveis das regressōes } \\
\hline $\mathrm{F}$ & $\mathrm{R}^{2}$ & $\mathrm{~d}_{2 \mathrm{t} .6}$ (FCG) & Constante & dummy3 & dummy 4 & dummy5 & IMP180 18 & IMP $180_{t-2}$ \\
\hline $8,17^{\star}$ & 0,51 & 0,031 & $17,07^{\star}$ & $-5,58^{\star \star \star \star}$ & $-11,60^{\star}$ & $-7,02^{\star \star}$ & $0,58^{*}$ & $-0,21$ \\
\hline $\mathrm{F}$ & $\overline{\mathrm{R}}^{2}$ & $\mathrm{~d}_{2 \mathrm{t}-7}(\mathrm{FCG})$ & Constante & dummy3 & dummy 4 & dummy5 & IMP180t-1 & IMP180t-2 \\
\hline $9,27^{\star}$ & 0,55 & $-0,0090$ & $22,42^{*}$ & $-7,88^{\star \star}$ & $-14,30^{\star}$ & $-9,11^{\star \star}$ & $0,51^{\star}$ & $-0,24$ \\
\hline $\mathrm{F}$ & $\overline{\mathrm{R}^{2}}$ & $\mathrm{~d}_{2 \mathrm{t} \cdot 8}$ (FCG) & Constante & dummy3 & dummy4 & dummy5 & IMP180 18 & IMP180 18 \\
\hline $10,43^{\star}$ & 0,59 & 0,020 & $26,66^{\star}$ & $-10,54^{\star}$ & $-18,42^{\star}$ & $-12,74^{\star}$ & $0,44^{*}$ & $-0,27^{\star \star \star *}$ \\
\hline $\mathrm{F}$ & $\overline{\mathrm{R}^{2}}$ & $\mathrm{~d}_{2 \mathrm{t}-9}(\mathrm{FCG})$ & Constante & dummy3 & dummy4 & dummy5 & IMP180 18 & IMP180 18 \\
\hline $10,48^{\star}$ & 0,60 & 0,050 & $30,42^{\star}$ & $-13,08^{\star}$ & $-22,20^{\star}$ & $-16,14^{\star}$ & $0,39^{\star \star}$ & $-\overline{0}, 31 \star \star \star-7$ \\
\hline $\mathrm{F}$ & $\overline{\mathrm{R}}^{2}$ & $\mathrm{~d}_{2 t-10}(\mathrm{FCG})$ & Constante & dummy3 & dummy4 & dummy5 & IMP180t-1 & IMP180t-2 \\
\hline $8,49^{\star}$ & $0, \overline{55}$ & 0,12 & $18,95^{\star \star}$ & $-6,53$ & $-14,55^{\star \star}$ & $-9,87^{\star \star \star}$ & $0,43^{\star}$ & $-0,20$ \\
\hline$F$ & $\overline{R^{2}}$ & $\mathrm{~d}_{2 t \cdot 11}(\mathrm{FCG})$ & Constante & dummy3 & dummy4 & dummy5 & IMP180t-1 & IMP180t-2 \\
\hline $7,51^{\star}$ & 0,52 & 0,088 & $27,25^{\star}$ & $-13,42^{\star \star}$ & $-21,35^{\star}$ & $-16,85^{\star \star}$ & $0,54^{\star}$ & $-0,33^{\star \star}$ \\
\hline$F$ & $\overline{\mathrm{R}^{2}}$ & $\mathrm{~d}_{2 \mathrm{t} .12}(\mathrm{FCG})$ & Constante & dummy3 & dummy4 & & IMP180t-1 & IMP180t.2 \\
\hline $6,78^{\star}$ & 0,45 & $-0,019$ & $14,43^{\star \star}$ & 1,38 & $-5,68^{\star \star \star}$ & & $0,58^{\star}$ & $-0,34^{\star \star}$ \\
\hline$F$ & $\overline{\mathrm{R}^{2}}$ & $\mathrm{~d}_{2 \mathrm{t} \cdot 6}(\mathrm{CDB})$ & Constante & dummy3 & dummy4 & dummy5 & IMP $180_{t-1}$ & IMP180t-2 \\
\hline $8,20^{\star}$ & 0,51 & $-0,052$ & $18,18^{\star}$ & $-5,57^{\star \star \star \star}$ & $-11,01^{\star}$ & $-6,52^{\star t}$ & $0,57^{\star}$ & $-0,22$ \\
\hline $\bar{F}$ & $\overline{\mathrm{R}^{2}}$ & $\mathrm{~d}_{2 \mathrm{t}-7}(\mathrm{CDB})$ & Constante & dummy3 & dummy4 & dummy5 & IMP180t-1 & IMP $180_{t 2}$ \\
\hline $9,27^{\star}$ & 0,55 & 0,0061 & $22,12^{\star}$ & $-7,84^{\star \star}$ & $-14,41^{\star}$ & $-9,24^{\star}$ & $0,51^{\star}$ & $-0,24$ \\
\hline$F$ & $\overline{\overline{\mathrm{R}}^{2}}$ & $\mathrm{~d}_{2 \mathrm{t} .8}(\mathrm{CDB})$ & Constante & dummy3 & dummy4 & dummy5 & IMP180 & IMP180t.2 \\
\hline $10,44^{\star}$ & 0,59 & 0,033 & $26,97^{\star}$ & $-10,51^{\star}$ & $-18,26^{\star}$ & $-12,46^{\star}$ & $0,44^{\star}$ & $-0,26^{\star \star \star}$ \\
\hline $\bar{F}$ & $\overline{\mathrm{R}^{2}}$ & $d_{2 t .9}(C D B)$ & Constante & dummy3 & dummy 4 & dummy5 & IMP180 & IMP180t.2 \\
\hline $10,45^{\star}$ & 0,60 & 0,057 & $31,36^{\star}$ & $-12,93^{*}$ & $-21,76^{\star}$ & $-15,39^{\star}$ & $0,39^{\star \star}$ & $-0,30^{\star \star}$ \\
\hline $\mathrm{F}$ & $\overline{\mathrm{R}^{2}}$ & $\mathrm{~d}_{2 \mathrm{t}-10}(\mathrm{CDB})$ & Constante & dummy3 & dummy4 & dummy5 & IMP180t-1 & IMP180t.2 \\
\hline $8,56^{\star}$ & 0,55 & 0,16 & $21,75^{\star}$ & $-6,37$ & $-14,03^{\star \star}$ & $-8,39^{\star \star \star}$ & $0,42^{\star}$ & $-0,20$ \\
\hline $\mathrm{F}$ & $\overline{\mathrm{R}^{2}}$ & $\mathrm{~d}_{2 t-11}(\mathrm{CDB})$ & Constante & dummy3 & dummy4 & dummy5 & IMP180 18 & IMP180t.2 \\
\hline $7,80^{\star}$ & 0,53 & 0,16 & $30,65^{\star}$ & $-14,18^{\star \star}$ & $-22,26^{\star}$ & $-17,02^{\star \star}$ & $0,52^{\star}$ & $-0,34^{\star \star}$ \\
\hline F & $\mathrm{R}^{2}$ & $\mathrm{~d}_{2 \mathrm{t} \cdot 12}(\mathrm{CDB})$ & Constante & dummy3 & dummy 4 & & IMP $180_{t-1}$ & IMP180 \\
\hline $6,80^{\star}$ & 0,45 & 0,048 & $13,55^{\star}$ & 2,21 & $-5,17^{\star \star}$ & & $0,56^{\star}$ & $-0,35^{\star \star}$ \\
\hline
\end{tabular}

Notas: ${ }^{*}$ significativo a $1 \% ;{ }^{* *}$ significativo a $5 \%$; ${ }^{* * *}$ significativo a $10 \%$. 
Com relação às importações financiadas com prazo de 181 até 360 dias, o melhor ajustamento foi obtido através do modelo no qual foi incluída uma variável binária para quebra estrutural em janeiro de 1997, conforme descrito pela equação abaixo:

$$
\begin{aligned}
& I M P 181_{t}=a+b_{2} d u m m y 2+d_{j_{t-i}}(F C G o u C D B)+I M P 181_{t-1}+ \\
& +I M P 181_{t-2}+e_{t}
\end{aligned}
$$

IMP181 $\mathrm{t}=$ importações financiadas de 181 até 160 dias no momento t; dummy 2 = variável binária, a qual assume o valor zero até dezembro de 1996 (inclusive) e valor um a partir de janeiro de 1997 (inclusive);

$d_{j}$ t-i $(F C G$ ou CDB $)=$ diferença entre o custo do financiamento do capital de giro (FCG) ou CDB e o custo de captação de recursos externos, no momento t-i; $i=6$ a 12 em cada modelo. Quando $j=1$, refere-se ao FCG ou CDB, descontando-se a variação cambial $\left(d_{1}\right)$ e quando $j=2$, corresponde ao custo efetivo real do FCG ou CDB $\left(\mathrm{d}_{2}\right)$.

IMP181 $1_{\mathrm{t}-1}=$ importações financiadas de 181 até 360 dias no momento t1 ;

IMP180 1 -2 $=$ importações financiadas de 181 até 360 dias no momento t2 ;

$\mathrm{e}_{\mathrm{t}}=$ ruído branco.

Da mesma forma que anteriormente, foram estimadas 28 regressões, uma correspondente a cada diferencial entre as taxas de juros nos mercados interno e externo $\left(d_{1}\right.$ para o CDB, $d_{1}$ para o $F C G, d_{2}$ para o CDB e $d_{2}$ para o FCG), nas defasagens sucessivas de 6 até 12 periodos. Os resultados das regressões estimadas conforme a equaçāo acima encontram-se nas Tabelas A3 e A4. 
Tabela A3. Resultados das regressões entre as importações financiadas de 181 até 360 dias e os diferenciais entre as taxas de juros nos mercados interno e externo $\left(\mathrm{d}_{1}\right)$, considerando-se o FCG e o CDB.

\begin{tabular}{|c|c|c|c|c|c|c|}
\hline \multicolumn{2}{|c|}{$\begin{array}{l}\text { Análises de } \\
\text { regressāo }\end{array}$} & \multicolumn{5}{|c|}{ Coeficientes das variáveis das regressōes } \\
\hline $\mathrm{F}$ & $\bar{R}^{2}$ & $\mathrm{~d}_{1 \mathrm{t} \cdot 6}(\mathrm{FCG})$ & Constante & dummy2 & IMP18 $11_{t-1}$ & IMP $181_{t-2}$ \\
\hline $124,56^{\star}$ & 0,92 & $-0,027$ & $52,34^{\star}$ & $-49,37^{\star}$ & $-0,080$ & $0,34^{*}$ \\
\hline$F$ & $\overline{\mathrm{R}^{2}}$ & $\mathrm{~d}_{1 \mathrm{t} .7}(\mathrm{FCG})$ & Constante & dummy2 & IMP181t-1 & IMP181t-2 \\
\hline $120,13^{\star}$ & 0,92 & $-0,083$ & $48,97^{\star}$ & $-44,79^{\star}$ & $-0,065$ & $0,36^{\star}$ \\
\hline $\bar{F}$ & $\overline{\mathrm{R}^{2}}$ & $\mathrm{~d}_{\mathrm{t} \cdot \mathrm{s}}(\mathrm{FCG})$ & Constante & dummy2 & IMP18 $11_{t-1}$ & IMP18 1 t.2 \\
\hline $122,42^{\star}$ & 0,93 & $-0,068$ & $51,85^{\star}$ & $-47,95^{\star}$ & $-0,034$ & $0,33^{*}$ \\
\hline$F$ & $\overline{R^{2}}$ & $\mathrm{~d}_{1 \mathrm{t} .9}(\mathrm{FCG})$ & Constante & dummy2 & IMP181 1 & IMP18 $11_{t-2}$ \\
\hline $89,40^{\star}$ & 0,90 & $-0,036$ & $49,98^{\star}$ & $-46,97^{\star}$ & $-0,019$ & $0,32^{\star}$ \\
\hline $\mathrm{F}$ & $\overline{\mathrm{R}^{2}}$ & $\mathrm{~d}_{1 \mathrm{t}-10}(\mathrm{FCG})$ & Constante & dummy2 & IMP18 18 & IMP18 $11_{t-2}$ \\
\hline $108,90^{\star}$ & 0,92 & $-0,064$ & $38,99^{\star}$ & $-35,42^{\star}$ & $-0,12^{\star \star \star}$ & $0,44^{\star}$ \\
\hline$F$ & $\overline{\mathrm{R}^{2}}$ & $\overline{d_{1 t-11}(F C G)}$ & Constante & dummy2 & IMP181t-1 & \\
\hline $46,13^{\star}$ & 0,79 & $-0,056$ & $64,18^{\star}$ & $-59,69^{\star}$ & $0,24^{\star}$ & \\
\hline$F$ & $\overline{\mathrm{R}^{2}}$ & $\mathrm{~d}_{1 \mathrm{t} \cdot 12}(\mathrm{FCG})$ & Constante & & IMP18 $11_{t-1}$ & \\
\hline $5,94^{\star}$ & 0,22 & $-0,14$ & $7,02^{\star \star \star}$ & & $0,23^{\star}$ & \\
\hline$F$ & $\overline{\bar{R}^{2}}$ & $\mathrm{~d}_{1 \mathrm{t} \cdot 6}(\mathrm{CDB})$ & Constante & dummy2 & IMP181 $1_{t-1}$ & IMP181t-2 \\
\hline $124,62^{\star}$ & 0,92 & $-0,031$ & $51,36^{\star}$ & $-49,24^{\star}$ & $-0,078$ & $0,35^{\star}$ \\
\hline$F$ & $\overline{\mathrm{R}^{2}}$ & $\mathrm{~d}_{\mathrm{t} t-7}(\mathrm{CDB})$ & Constante & dummy 2 & IMP181t:1 & IMP181t.2 \\
\hline $116,06^{\star}$ & 0,92 & $-0,022$ & $46,08^{\star}$ & $-44,22^{\star}$ & $-0,064$ & $0,37^{\star}$ \\
\hline $\mathrm{F}$ & $\overline{\mathrm{R}^{2}}$ & $\mathrm{~d}_{1 \mathrm{t}-8}(\mathrm{CDB})$ & Constante & dummy2 & IMP181 & IMP18 $1_{t-2}$ \\
\hline $120,39^{\star}$ & 0,93 & $-0,044$ & $49,40^{\star}$ & $-47,48^{\star}$ & $-0,025$ & $0,33^{\star}$ \\
\hline $\mathrm{F}$ & $\overline{R^{2}}$ & $d_{1 t-9}(C D B)$ & Constante & dummy2 & IMP181t-1 & IMP18 $1_{t-2}$ \\
\hline $89,40^{\star}$ & 0,90 & $-0,042$ & $49,03^{\star}$ & $-47,08^{\star}$ & $-0,021$ & $0,33^{\star}$ \\
\hline $\bar{F}$ & $\overline{\mathrm{R}^{2}}$ & $\mathrm{~d}_{1 \mathrm{t} \cdot 10}(\mathrm{CDB})$ & Constante & dummy2 & IMP181t-1 & IMP18 $1_{t \cdot 2}$ \\
\hline $107,35^{\star}$ & 0,92 & $-0,064$ & $37,01^{\star}$ & $-35,33^{\star}$ & $-0,11^{\star \star \star}$ & $0,44^{\star}$ \\
\hline F & $\overline{\mathrm{R}^{2}}$ & $\mathrm{~d}_{1 \mathrm{t}-11}(\mathrm{CDB})$ & Constante & dummy2 & IMP181t-1 & \\
\hline $45,74^{\star}$ & 0,79 & $-0,046$ & $62,26^{\star}$ & $-59,39^{\star}$ & $0,24^{\star}$ & \\
\hline $\mathrm{F}$ & $\overline{\mathrm{R}}^{2}$ & $d_{1 t-12}(C D B)$ & Constante & & IMP18 $11_{t-1}$ & \\
\hline $5,71^{\star}$ & 0,21 & $-0,27$ & $3,29 *$ & & $0,24^{\star}$ & \\
\hline
\end{tabular}

Notas: ${ }^{*}$ significativo a $1 \% ;{ }^{* *}$ significativo a $5 \% ;^{* * *}$ significativo a $10 \%$. 
Tabela A4. Resultados das regressões entre as importações finnanciadas de 181 até 360 dias e os diferenciais entre as taxas de juros nos mercados interno e externo $\left(\mathrm{d}_{2}\right)$, considerando-se o FCG e o CDB.

\begin{tabular}{|c|c|c|c|c|c|c|}
\hline \multicolumn{2}{|c|}{$\begin{array}{l}\text { Análises de } \\
\text { regressão }\end{array}$} & \multicolumn{5}{|c|}{ Coeficientes das variáveis das regressōes } \\
\hline $\mathrm{F}$ & $\overline{R^{2}}$ & $\mathrm{~d}_{2 \mathrm{t} \cdot 6}(\mathrm{FCG})$ & Constante & dummy2 & IMP181 1 -1 & IMP181t-2 \\
\hline $124,11^{\star}$ & 0,92 & 0,0095 & $50,99^{\star}$ & $-49,08^{\star}$ & $-0,075$ & $0,34^{\star}$ \\
\hline$F$ & $\overline{\mathrm{R}^{2}}$ & $\mathrm{~d}_{2 \mathrm{t} \cdot \mathrm{7}}(\mathrm{FCG})$ & Constante & dummy2 & IMP18 $11_{t-1}$ & IMP181t-2 \\
\hline $116,09^{*}$ & 0,92 & 0,025 & $44,90^{\star}$ & $-43,87^{\star}$ & $-0,062$ & $0,38^{\star}$ \\
\hline $\mathrm{F}$ & $\bar{R}^{2}$ & $\mathrm{~d}_{2 \mathrm{t} \cdot 8}(\mathrm{FCG})$ & Constante & dummy2 & IMP181t.1 & IMP181:2 \\
\hline $120,06^{\star}$ & 0,92 & $-0,036$ & $51,32^{\star}$ & $-48,01^{\star}$ & $-0,029$ & $0,32^{\star}$ \\
\hline $\mathrm{F}$ & $\overline{\mathrm{R}^{2}}$ & $\mathrm{~d}_{2 \mathrm{t} \cdot 9}(\mathrm{FCG})$ & Constante & dummy2 & IMP181 & IMP181t-2 \\
\hline $93,20^{\star}$ & 0,91 & $-0,11$ & $53,57^{\star}$ & $-47,94^{\star}$ & $-0,025$ & $0,31^{\star}$ \\
\hline $\bar{F}$ & $\bar{R}^{2}$ & $\mathrm{~d}_{2 \mathrm{t} \cdot 10}(\mathrm{FCG})$ & Constante & dummy2 & IMP181t-1 & IMP181t-2 \\
\hline $111,68^{\star}$ & 0,93 & $-0,088$ & $40,54^{\star}$ & $-35,88^{\star}$ & $-0,12^{\star \star \star}$ & $0,43^{\star}$ \\
\hline $\mathrm{F}$ & $\overline{\mathrm{R}^{2}}$ & $\mathrm{~d}_{2 t-11}(\mathrm{FCG})$ & Constante & dummy 2 & IMP181t.1 & \\
\hline $46,46^{\star}$ & 0,79 & $-0,067$ & $64,50^{\star}$ & $-59,42^{\star}$ & $0,23^{\star}$ & \\
\hline$F$ & $\overline{R^{2}}$ & $\mathrm{~d}_{2 \mathrm{t}-12}(\mathrm{FCG})$ & Constante & dummy 2 & IMP181t-1 & \\
\hline $5,20^{\star}$ & 0,19 & $-0,038$ & 4,12 & & $0,24^{\star}$ & \\
\hline $\bar{F}$ & $\overline{\mathrm{R}^{2}}$ & $\mathrm{~d}_{2 \mathrm{t} \cdot 6}(\mathrm{CDB})$ & Constante & dummy2 & IMP181t-1 & IMP18 $11_{t-2}$ \\
\hline $124,07^{\star}$ & 0,92 & $-0,0035$ & $51,43^{\star}$ & $-49,16^{\star}$ & $-0,077$ & $0,34^{\star}$ \\
\hline F & $\overline{\mathrm{R}^{2}}$ & $\mathrm{~d}_{2 . \mathrm{t} \cdot \mathrm{7}}(\mathrm{CDB})$ & Constante & dummy 2 & IMP181t-1 & IMP18 $11_{t-2}$ \\
\hline $123,22^{\star}$ & 0,92 & 0,19 & $44,22^{\star}$ & $-43,00^{\star}$ & $-0,059$ & $0,40^{\star}$ \\
\hline$F$ & $\overline{\mathrm{R}^{2}}$ & $\mathrm{~d}_{2 \mathrm{t}-8}(\mathrm{CDB})$ & Constante & dummy 2 & IMP181t-1 & IMP18 1 t-2 \\
\hline $119,43^{\star}$ & 0,92 & $-0,014$ & $49,61^{\star}$ & $-47,54^{\star}$ & $-0,024$ & $0,33^{*}$ \\
\hline$F$ & $\overline{\bar{R}^{2}}$ & $\mathrm{~d}_{2 \mathrm{t}-\mathrm{g}}(\mathrm{CDB})$ & Constante & dummy 2 & IMP181 & IMP18 1t-2 \\
\hline $95,68^{\star}$ & 0,91 & $-0,19$ & $51,40^{\star}$ & $-48,82^{\star}$ & $-0,032$ & $0,32^{\star}$ \\
\hline $\mathrm{F}$ & $\overline{\mathrm{R}^{2}}$ & $d_{2 t-10}(C D B)$ & Constante & dummy 2 & IMP181t-1 & IMP18 18 \\
\hline $111,85^{\star}$ & 0,92 & $-0,13$ & $37,93^{\star}$ & $-35,83^{\star}$ & $-0,11^{\star \star \star}$ & $0,44^{\star}$ \\
\hline $\bar{F}$ & $\overline{\bar{R}^{2}}$ & $\mathrm{~d}_{2 \mathrm{t}-11}(\mathrm{CDB})$ & Constante & dummy 2 & IMP181t-1 & \\
\hline $46,18^{\star}$ & 0,79 & $-0,092$ & $62,26^{\star}$ & $-59,09^{\star}$ & $0,24^{\star}$ & \\
\hline F & $\overline{\bar{R}^{2}}$ & $\mathrm{~d}_{2 t-12}(\mathrm{CDB})$ & Constante & dummy 2 & IMP181t-1 & \\
\hline $5,10^{\star \star}$ & 0,19 & 0,023 & 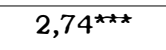 & & $0,25^{\star}$ & \\
\hline
\end{tabular}

Notas: ${ }^{*}$ significativo a $1 \% ;^{* \star}$ significativo a $5 \% ;{ }^{* \star \star}$ significativo a $10 \%$. 
Para as importaçōes financiadas totais, todos os modelos testados (quanto à inclusão de uma variável binária para mudança estrutural, tendência e variáveis binárias anuais) proporcionaram a mesma qualidade de ajustamento. Em nenhum deles a variável diferencial de taxas de juros defasada apresentou-se significativa. Optou-se por apresentar os resultados do modelo no qual incluiu-se uma variável binária para quebra estrutural em novembro de 1997, conforme descrito pela equação abaixo:

$$
\begin{aligned}
& \text { IMPtotais }_{t}=a+b_{1} \text { dummyl }_{+} d_{j_{t-i}}(\text { FCGouCDB })+\text { IMPtotais }_{t-1}+ \\
& + \text { IMPtotais }_{t-2}+\text { IMPtotais }_{t-3}+e_{t}
\end{aligned}
$$

IMPtotais $\mathrm{t}_{\mathrm{t}}$ importaçōes financiadas totais no momento t;

dummy 1 = variável binária, a qual assume o valor zero até outubro de 1997 (inclusive) e valor um a partir de novembro de 1997 (inclusive);

$d_{j}$ t-i $(F C G$ ou CDB $)=$ diferença entre o custo do financiamento do capital de giro (FCG) ou CDB e o custo de captação de recursos externos, no momento t-i; i = 6 a 12 em cada modelo. Quando $j=1$, refere-se ao FCG ou $\mathrm{CDB}$, descontando-se a variação cambial $\left(\mathrm{d}_{1}\right)$ e quando $\mathrm{j}=2$, corresponde ao custo efetivo real do FCG ou CDB $\left(\mathrm{d}_{2}\right)$.

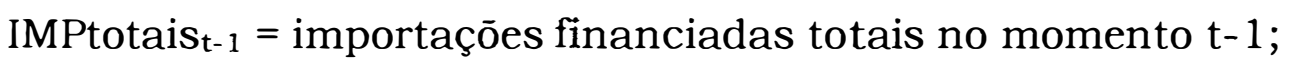

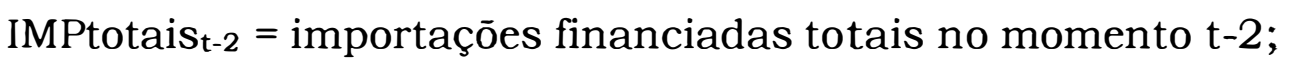

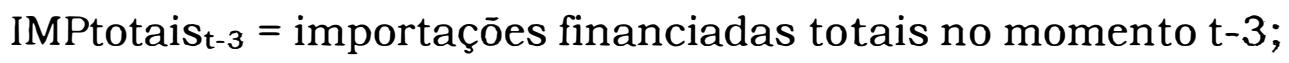

$\mathrm{e}_{\mathrm{t}}=$ ruído branco.

Os resultados das 28 regressōes estimadas conforme a equação acima são apresentados nas Tabelas A5 e A6. 
Tabela A5. Resultados das regressões entre as importações financiadas totais e os diferenciais entre as taxas de juros nos mercados interno e externo $\left(\mathrm{d}_{1}\right)$, considerando-se o FCG e o CDB.

\begin{tabular}{|c|c|c|c|c|c|c|c|}
\hline \multicolumn{2}{|c|}{$\begin{array}{l}\text { Análises de } \\
\text { regressāo }\end{array}$} & \multicolumn{6}{|c|}{ Coeficientes das variáveis das regressões } \\
\hline$F$ & $\overline{\mathrm{R}}^{2}$ & $\mathrm{~d}_{\mathrm{t} t-6}(\mathrm{FCG})$ & Constante & dummy 1 & IMPtotaist-1 & IMPtotaist-2 & IMPtotais $\mathbf{t}_{\mathrm{t}-3}$ \\
\hline $19,28^{\star}$ & 0,69 & $0,30^{\star \star \star}$ & $51,58^{\star}$ & $-31,24^{\star}$ & 0,18 & $0,34^{\star \star}$ & $-0,25^{\star \star \star \star}$ \\
\hline $\mathrm{F}$ & $\overline{\mathrm{R}}^{2}$ & $\mathrm{~d}_{1 \mathrm{t} \cdot 7}(\mathrm{FCG})$ & Constante & dummy 1 & IMPtotaist-1 & IMPtotais $\mathrm{t} \cdot 2$ & IMPtotaist -3 \\
\hline $16,49^{\star}$ & 0,66 & 0,12 & $51,11^{*}$ & $-28,64^{\star}$ & 0,22 & $0,36^{\star \star}$ & $-0,24^{\star \star \star \star}$ \\
\hline$F$ & $\overline{\mathrm{R}^{2}}$ & $\mathrm{~d}_{1 \mathrm{t}-8}(\mathrm{FCG})$ & Constante & dummy 1 & IMPtotais $\mathbf{t}_{\mathrm{I}}$ & IMPtotais $\mathrm{t}_{-2}$ & IMPtotaist-3 \\
\hline $16,98^{\star}$ & 0,67 & 0,15 & $52,81^{\star}$ & $-30,30^{\star}$ & 0,26 & $0,33^{\star \star}$ & $-0,28^{\star \star \star x}$ \\
\hline$F$ & $\overline{\mathrm{R}^{2}}$ & $\mathrm{~d}_{1 \mathrm{t} \cdot \mathrm{g}}(\mathrm{FCG})$ & Constante & dummy 1 & IMPtotaist-1 & IMPtotais $_{t-2}$ & IMPtotais $\mathrm{t}_{-3}$ \\
\hline $15,08^{\star}$ & 0,65 & 0,044 & $51,47^{\star}$ & $-27,57^{\star}$ & $0,29^{\star \star \star}$ & $0,32^{\star \star}$ & $-0,26^{\star \star \star}$ \\
\hline$F$ & $\overline{\mathrm{R}}^{2}$ & $\mathrm{~d}_{1 \mathrm{t}-10}(\mathrm{FCG})$ & Constante & dummy 1 & IMPtotais $_{\mathrm{t}-1}$ & IMPtotais $\mathrm{I}_{\mathrm{t} 2}$ & IMPtotais $t_{-3}$ \\
\hline $17,91^{\star}$ & 0,70 & $-0,020$ & $51,29^{\star}$ & $-24,69^{\star}$ & 0,18 & $0,43^{*}$ & $-0,29^{\star \star}$ \\
\hline $\mathrm{F}$ & $\overline{R^{2}}$ & $\mathrm{~d}_{1 \mathrm{t} \cdot 11}(\mathrm{FCG})$ & Constante & dummy 1 & IMPtotaist-1 & IMPtotaist.2 & IMPtotaist.3 \\
\hline $17,51^{\star}$ & 0,70 & $-0,040$ & $48,43^{\star}$ & $-23,36^{\star}$ & $0,29^{\star \star \star}$ & $0,45^{\star}$ & $-0,35^{\star}$ \\
\hline$F$ & $\overline{\mathrm{R}^{2}}$ & $\mathrm{~d}_{1,12}(\mathrm{FCG})$ & Constante & dummy 1 & IMPtotaist 1 & IMPtotaist-2 & IMPtotais $_{\mathrm{t}-3}$ \\
\hline $19,79^{\star}$ & 0,73 & $-0,78^{\star}$ & $79,75^{\star}$ & $-22,86^{\star}$ & $0,26^{\star \star \star}$ & $0,32^{\star \star}$ & $-0,39^{\star}$ \\
\hline $\mathrm{F}$ & $\overline{\mathrm{R}^{2}}$ & $\mathrm{~d}_{1 \mathrm{t} .6}(\mathrm{CDB})$ & Constante & dummy 1 & IMPtotaist-1 & IMPtotaist-2 & IMPtotaist -3 \\
\hline $18,62^{\star}$ & 0,68 & 0,28 & $59,36^{\star}$ & $-29,19^{\star}$ & 0,20 & $0,33^{\star \star}$ & $-0,26^{\star \star}$ \\
\hline $\mathrm{F}$ & $\overline{\mathrm{R}}^{2}$ & $\mathrm{~d}_{1 \mathrm{t} .7}(\mathrm{CDB})$ & Constante & dummy 1 & IMPtotais $_{\mathrm{t}-\mathrm{I}}$ & IMPtotaist.2 & IMPtotaist-3 \\
\hline $17,33^{\star}$ & 0,67 & 0,28 & $57,07^{\star}$ & $-28,36^{\star}$ & 0,20 & $0,35^{\star \star}$ & $-0,26^{\star \star \star x}$ \\
\hline$F$ & $\overline{\mathrm{R}}^{2}$ & $\mathrm{~d}_{1 \mathrm{t} \cdot 8}(\mathrm{CDB})$ & Constante & dummy 1 & IMPtotaist - 1 & IMPtotaist-2 & IMPtotaist-3 \\
\hline $17,78^{\star}$ & 0,68 & 0,31 & $59,46^{\star}$ & $-30,05^{\star}$ & 0,24 & $0,32^{\star \star}$ & $-0,29^{\star \star}$ \\
\hline$F$ & $\overline{\mathrm{R}^{2}}$ & $\mathrm{~d}_{1 \mathrm{t} \cdot 9}(\mathrm{CDB})$ & Constante & dummy 1 & IMPtotaist-1 & IMPtotaist-2 & IMPtotais ${ }_{t-3}$ \\
\hline $15,73^{\star}$ & 0,66 & 0,26 & $56,21^{\star}$ & $-28,45^{\star}$ & 0,26 & $0,31^{\star \star}$ & $-0,27^{\star \star \star}$ \\
\hline $\mathrm{F}$ & $\overline{\bar{R}^{2}}$ & $\mathrm{~d}_{1 \mathrm{t} \cdot 10}(\mathrm{CDB})$ & Constante & dummy 1 & IMPtotais $\mathrm{t}_{-1}$ & IMPtotaist-2 & IMPtotaist \\
\hline $18,22^{\star}$ & 0,70 & 0,15 & $52,82^{\star}$ & $-25,48^{\star}$ & 0,17 & $0,42^{\star}$ & $-0,29^{\star \star}$ \\
\hline F & $\overline{\mathrm{R}}^{2}$ & $d_{1 t 11}(C D B)$ & Constante & dummy 1 & IMPtotaist-1 & IMPtotaist-2 & IMPtotaist-3 \\
\hline $17,56^{\star}$ & 0,70 & 0,087 & $47,80^{\star}$ & $-23, \overline{70^{\star}}$ & $0,29^{\star \star \star}$ & $0,45^{\star}$ & $-0,36^{\star}$ \\
\hline $\mathrm{F}$ & $\overline{\mathrm{R}^{2}}$ & $d_{1 t-12}(C D B)$ & Constante & dummy 1 & IMPtotais $\mathrm{t}-\mathrm{I}$ & IMPtotaist-2 & IMPtotaist -3 \\
\hline $15,53^{*}$ & 0,68 & $-0,85$ & $50,47^{\star}$ & $-22,84^{\star}$ & $0,30^{x+x}$ & $0,37^{*}$ & $-0,34^{*}$ \\
\hline
\end{tabular}

Notas: * significativo a $1 \%{ }^{* *}$ significativo a $5 \% ;{ }^{* * *}$ significativo a $10 \%$. 
Tabela A6. Resultados das regressões entre as importações financiadas totais e os diferenciais entre as taxas de juros nos mercados interno e externo $\left(\mathrm{d}_{2}\right)$, considerando-se o FCG e o CDB.

\begin{tabular}{|c|c|c|c|c|c|c|c|}
\hline \multicolumn{2}{|c|}{$\begin{array}{l}\text { Análises de } \\
\text { regressão }\end{array}$} & \multicolumn{6}{|c|}{ Coeficientes das variáveis das regressōes } \\
\hline $\mathrm{F}$ & $\mathrm{R}^{2}$ & $\mathrm{~d}_{2 \mathrm{t} .6}(\mathrm{FCG})$ & Constante & dummy 1 & IMPtotais $\cdot 1$ & IMPtotaist -2 & IMPtotaist -3 \\
\hline $17,29^{\star}$ & 0,67 & 0,020 & $53,77^{\star}$ & $-29,01^{\star}$ & 0,24 & $0,36^{\star \star}$ & $-0.26^{\star \star \star}$ \\
\hline $\mathrm{F}$ & $\overline{R^{2}}$ & $\mathrm{~d}_{2 \mathrm{t}-7}(\mathrm{FCG})$ & Constante & dummy 1 & IMPtotaist-1 & IMPtotais $\mathrm{t}_{-2}$ & IMPtotais $t-3$ \\
\hline $16,35^{\star}$ & 0,66 & $-0,089$ & $55,60^{\star}$ & $-26,75^{\star}$ & 0,24 & $0,35^{\star \star}$ & $-0.26^{x t}$ \\
\hline $\mathrm{F}$ & $\bar{R}^{2}$ & $\mathrm{~d}_{2 \mathrm{t}-8}(\mathrm{FCG})$ & Constante & dummy 1 & IMPtotaist $\cdot 1$ & IMPtotaist.2 & IMPtotaist.3 \\
\hline $16,63^{\star}$ & 0,67 & $-0,052$ & $56,72^{\star}$ & $-28,71^{\star}$ & $0, \overline{27}$ & $0,35^{\star \star}$ & $-0.29^{\approx \pi *}$ \\
\hline $\mathrm{F}$ & $\bar{R}^{2}$ & $\mathrm{~d}_{2 \mathrm{t} \cdot \mathrm{9}}(\mathrm{FCG})$ & Constante & dummy 1 & IMPtotais $\mathrm{I}_{\mathrm{t}}$ & IMPtotais t-2 & IMPtotaist-3 \\
\hline $15,41^{\star}$ & $\overline{0}, \overline{66}$ & $-0,19$ & $58,17^{\star}$ & $-25,66^{\star}$ & $0,30^{\star \star \star}$ & $0,31^{\star \star}$ & $-0.28^{\star \star \star}$ \\
\hline $\mathrm{F}$ & $\mathrm{R}^{2}$ & $\mathrm{~d}_{2 \mathrm{t} \cdot 10}(\mathrm{FCG})$ & Constante & dummy 1 & IMPtotaist $\cdot \mathbf{I}$ & IMPtotais $\mathrm{t} \cdot 2$ & IMPtotais $\cdot 3$ \\
\hline $18,29^{\star}$ & 0,70 & $-0,15$ & $56,48^{\star}$ & $-24,13^{\star}$ & $0, \overline{17}$ & $0,43^{\star}$ & $-0.30^{\star}$ \\
\hline F & $\overrightarrow{R^{2}}$ & $\mathrm{~d}_{2 t \cdot 11(\mathrm{FCG})}$ & Constante & dummy 1 & IMPtotais $t_{-1}$ & IMPtotaist-2 & IMPtotaist.3 \\
\hline $17,67^{\star}$ & 0,70 & $-0,11$ & $52,14^{\star}$ & $-23,46^{\star}$ & $0,28^{\star \star \star}$ & $0,44^{\star}$ & $-0.36^{\star}$ \\
\hline $\mathrm{F}$ & $R^{2}$ & $\mathrm{~d}_{2 \mathrm{t}-12(\mathrm{FCG})}$ & Constante & dummy 1 & IMPtotaist -1 & IMPtotaist $\cdot 2$ & IMPtotaist.3 \\
\hline $18,17^{\star}$ & 0,71 & $-0,54^{\star \star}$ & $74,65^{\star}$ & $-23,08^{\star}$ & $0,30^{\star \star}$ & $0,33^{\star \star}$ & $-0.43^{\star}$ \\
\hline $\mathrm{F}$ & $\mathrm{R}^{2}$ & $\mathrm{~d}_{2 \mathrm{t}-6}(\mathrm{CDB})$ & Constante & dummy 1 & IMPtotaist - & IMPtotaist-2 & IMPtotaist.3 \\
\hline $17,29^{\star}$ & 0,67 & 0,033 & $54,44^{\star}$ & $-28,88^{\star}$ & 0,24 & $0,36^{\star \star}$ & $-0.26^{\star \star \star}$ \\
\hline F & $\mathrm{R}^{2}$ & $\mathrm{~d}_{2 \mathrm{t}-\mathrm{7}}(\mathrm{CDB})$ & Constante & dummy 1 & IMPtotais $_{t-1}$ & IMPtotaist -2 & IMPtotaist-3 \\
\hline $16,83^{\star}$ & 0,66 & 0,31 & $50,57^{\star}$ & $-28,07^{\star}$ & 0,24 & $0,38^{\star \star}$ & $-0.24^{\star \star \star}$ \\
\hline F & $R^{2}$ & $\mathrm{~d}_{2 \mathrm{t}-8}(\mathrm{CDB})$ & Constante & dummy 1 & IMPtotais $\mathrm{t}-\mathrm{I}$ & IMPtotaist -2 & IMPtotaist 3 \\
\hline $17,01^{\star}$ & 0,67 & 0,26 & $53,85^{\star}$ & $-29,67^{\star}$ & 0,25 & $0,35^{\star \star}$ & $-0.26^{\star \star \star}$ \\
\hline $\mathrm{F}$ & $\mathrm{R}^{2}$ & $d_{2 t-9}(C D B)$ & Constante & dummy 1 & IMPtotais ${ }_{t-1}$ & IMPtotaist-2 & IMPtotaist. 3 \\
\hline $15,13^{\star}$ & 0,65 & 0,12 & $52,19^{\star}$ & $-27,68$ & $0,28^{\star \star \star}$ & $0,32^{\star \star}$ & $-0.25^{\star \star \star}$ \\
\hline $\mathrm{F}$ & $\overline{R^{2}}$ & $\mathrm{~d}_{2 t \cdot 10}(\mathrm{CDB})$ & Constante & dummy 1 & IMPtotaist-1 & IMPtotaist-2 & IMPtotaist $\cdot 3$ \\
\hline $17,95^{\star}$ & 0,70 & 0,069 & $50,87^{\star}$ & $-25,01^{\star}$ & 0,18 & $0,43^{\star}$ & $-0.28^{\star \star}$ \\
\hline$F$ & $\overline{\mathrm{R}^{2}}$ & $\mathrm{~d}_{2 \mathrm{t}-11}(\mathrm{CDB})$ & Constante & dummy 1 & IMPtotaist-1 & IMPtotais $\mathrm{t} \cdot 2$ & IMPtotaist -3 \\
\hline $17,49^{\star}$ & 0,70 & 0,0070 & $47,23^{\star}$ & $-23,49^{\star}$ & $0,29^{\star \star \star}$ & $0,45^{\star}$ & $-0.35^{\star}$ \\
\hline$F$ & $\overline{\mathrm{R}^{2}}$ & $\mathrm{~d}_{2 \mathrm{t}-12}(\mathrm{CDB})$ & Constante & dummy 1 & IMPtotaist-1 & IMPtotaist.2 & IMPtotaist-3 \\
\hline $15,04^{\star}$ & 0,67 & $-0,46$ & $52,63^{\star}$ & $-23,15^{\star}$ & $0,32^{\star \star}$ & $0,37^{\star}$ & $-0.38^{\star}$ \\
\hline
\end{tabular}

Notas: * significativo a $1 \%$; ${ }^{* \star}$ significativo a $5 \%$; ${ }^{\star \star \star}$ significativo a $10 \%$. 


\section{REFERÊNCIAS BIBLIOGRÁFICAS}

ARBEX, M.; CARVALHO, V.D. Eficiência do mercado futuro de café brasileiro, no período de 1992 a 1998. Revista de Economia e Sociologia Rural, v.37, n.1, p. 97-113, jan./mar. 1999.

BAFFES, J.; AJWAD, M.I. Detecting price linkages: methodological issues and an application to the world market of cotton. Washington: The World Bank, July 1998. (Policy Research Working Paper). 36p.

BALANÇO ANUAL NACIONAL GAZETA MERCANTIL 1999. São Paulo, v.23, n. 23, jun. 1999. p. 274.

BANCO CENTRAL DO BRASIL. Quadro 13 - Captação de recursos externos (de 1992 a 1999). sudex.dibap.depec@bcb.gov.br (27 Mar. 2000)

BARBOSA, M.Z. Transformações do mercado brasileiro de algodão e a influência de políticas comerciais. Informações Econômicas, v.26, n.2, p. 11-21, fev. 1996.

BLACK, D.G. Success and failure of futures contracts: theory and empirical evidence. New York, 1986. 70p. (Monograph). Graduate School of Business Administration, New York University. 
BOLLMAN, K.; THOMPSON, S.; GARCIA, P. An analysis of the performance and failure of the Diammonium Phosphate futures contract. 1998. (mimeografado). 33p.

BOlSA De MERCADORIAS De SÃO PAUlO. Bolsa de Mercadorias de São Paulo: 1917-1987. São Paulo: Laserprint, 1987. 149p.

BOLSA DE MERCADORIAS \& FUTUROS. Estatísticas do mercado físico de algodão: janeiro de 1990 a dezembro de 1996. São Paulo: BM\&F, 1997. 72p.

BOLSA DE MERCADORIAS \& FUTUROS. Estatísticas do mercado físico de algodão: janeiro de 1990 a dezembro de 1999. São Paulo: $B M \& F, 2000 a .65 p$.

BOLSA DE MERCADORIAS \& FUTUROS. Sistema de recuperação de informação. datarestore@bmf.com.br (11 Jan. 2000b)

BROWN, S.L. A reformulation of the portfolio model of hedging. American Journal of Agricultural Economics. v.67, n.3, p.508-12, 1985.

CONAB. Dados de algodão. conabgepav@tba.com.br (23 Jul. 1999a)

CONAB. Preços do algodão em pluma em São Paulo (correção). conabgepav@tba.com.br (20 Jan.2000) 
DICKEY, D.A.; FULLER, W.A. Distribution of estimators for autorregressive time series with a unit root. Journal of the American Statistical Association. n. 74, p.427-31, 1979.

DICKEY, W.; FULLER,W.A. Likelihood ratio statistics for autoregressive time series with a unit root. Econometrica, v.49, n.4, p.1057-72. 1981.

DOYLE, M. Re: Cotton futures prices series. mgd@barchart.com (18 Mar. 1999a)

DOYLE, M. Re: Cotton futures prices series. mgd@barchart.com (12 Ago. 1999b)

EDERINGTON, L.H. The hedging performance of the new futures markets. Journal of Finance, v.34, n.1, p.157-70, 1979.

ENDERS, W. Applied econometric time series. New York: Willey, 1995. 433p.

ENGLE, R.F.; GRANGER, C.W.J. Cointegration and error correction: representation, estimation and testing. Econometrica, v.55, n.2, p.251-76, 1987.

ENGLE, R.F.; YOO, B.S. Forecasting and testing in co-integrated systems. Journal of Econometrics, v.35, n.1, p.143-159, 1987. 
FERREIRA, A.; HORITA, N. BM\&F: a história do mercado futuro no Brasil. São Paulo: Bolsa de Mercadorias \& Futuros e Cultura Editores Associados, 1996. 474p.

FERREIRA FILHO; J.B.S.; BARROS; G.S.A.C.; DE ZEN; S. Proposta de Plano de ação conjunta BM\&F/CEPEA para dinamização da utilização do mercado futuro do algodão em pluma como instrumento de comercialização. Piracicaba: CEPEA/BM\&F, 1998. 14p. (Relatório de Pesquisa).

FORBES, L.F. Mercados futuros: uma introdução. São Paulo: Bolsa de Mercadorias \& Futuros, 1994. 67p.

FULLER, W. Introduction to statistical time series. 2. ed. New York: John Wiley, 1996. 698p.

GEPPERT, J.M. A statistical model for the relationship between futures contract hedging effectiveness and investment horizon length. The Journal of Futures Markets, v.15, n.5, p. 507-536, 1995.

GONÇALVES, J.S. Crise do algodão brasileiro pós-abertura dos anos 90 e as condicionantes da retomada da expansão em bases competitivas. Informações Econômicas, v.27, n.3, p. 7-25, mar. 1997.

GORINI, A.F.; SIQUEIRA, S.G. O segmento de fiação no Brasil. BNDES Setorial, n.6, p.133-154, 1997.

HARRIS, R.I.D. Using co-integration analysis in econometric modeling. London: Prentice Hall/Harvester Wheatsheaf, 1995. 176p. 
HEIFNER, R.G. Optimal hedging levels and hedging effectiveness in cattle feeding. Agricultural Economics Research, v.24, n.2, p.2536, Apr. 1972.

INDICADORES DA AGROPECUÁRIA. Brasília, v.8 , n.2, fev. 1999. 50p.

INDICADORES DA AGROPECUÁRIA. Brasília, v.9, n.1, jan. 2000a. 50p.

INDICADORES DA AGROPECUÁRIA. Brasília, v.9, n.6 e 7, jun./jul. 2000b. 50p.

JAYO, M.; NUNES, R. Competitividade do sistema agroindustrial do algodão (compact disc). In: COMPETITIVIDADE NO AGRIBUSINESS BRASILEIRO. São Paulo: PENSA/FIA/FEA/USP, p.252-337, 1998.

JUROS \& MOEDAS: Banco de dados financeiros. São Paulo, v.2-8, $1994-2000$.

LEUTHOLD, R.M.; JUNKUS, J.C.; CORDIER; J.E. The theory and practice of futures markets. Massachusetts: Lexington Books, 1989. 410p.

LUNDBERG, E.L. (Coord.); KOYAMA, S.M.; CHU, V.Y.T.; SILVA, J.P.R.F.M. Juros e spread bancário no Brasil. São Paulo: Banco Central do Brasil, 1999. 88p.

MARQUES, P.V.; MELLO, P.C. Mercados futuros de commodities agropecuárias: exemplos e aplicaçōes para os mercados brasileiros. São Paulo: Bolsa de Mercadorias \& Futuros, 1999. 208p. 
MARSHALL, J.F. Futures and options contracting: theory and practice. Cincinnati: South-Western Publishing Co., 1989. 636p.

MYERS, R.J.; THOMPSON, S.R. Generalized optimal hedge ratio estimation. American Journal of Agricultural Economics, v.71, n.4, p. 858-867, Nov. 1989.

NOTÍCIAS BM\&F BRASIL. São Paulo, v.2, n.20, jan. 1999. 5p.

PERRON, P. The great crash, the oil price shock, and the unit root hypothesis. Econometrica, v. 57, n.6, p.1361-1401, Nov. 1989.

PHILLIPS, P.C.B. Time series regression with a unit root. Econometrica, v.55, n.2, p.277-301, 1987.

PHILlIPS, P.C.B.; PERRON, P. Testing for a unit root in time series regression. Biometrica, v.75, p. 335-46, 1988.

RESENHA BM\&.F. São Paulo: Bolsa de Mercadorias \& Futuros, n. 114, $121,128,136,1996$ - 1999.

REZENDE, G.C.; NONNENBERG, M.J.B.; MARQUES, M.C. Abertura comercial, financiamento das importações e o impacto sobre o setor agricola. Rio de Janeiro: IPEA, jul. 1997. (Texto para Discussão, 498). 
SABOYA, L.V.; BACCHI, M.R.P. Uma proposta metodológica para a análise da eficiência na formação de preços de contratos futuros (compact disc). In CONGRESSO BRASILEIRO DE ECONOMIA E SOCIOlOGIA RURAL, 37., Foz do Iguaçu, 1999. Anais. Brasília: Sociedade Brasileira de Economia e Sociologia Rural, 1999.

SATYANARAYAN,S.; THIGPEN,E.; VARANGIS,P. Hedging cotton price risk in Francophone African countries. Washington: The World Bank, Dec. 1993. 48p. (Policy Research Working Paper, 1233).

SPINOLA, N. O futuro do futuro: pequeno relatório de viagem ao mercado brasileiro de capitais e de trabalho no século XXI. São Paulo: Futura, 1997. 313p.

TEIXEIRA, M.A. Mercados futuros: fundamentos e características operacionais. São Paulo: Bolsa de Mercadorias \& Futuros, 1992. 53p.

URBAN, M.L.P.; BESEN, G.M.V.; GONÇALVES, J.S.; SOUZA, S.A.M. Estado e produção têxtil: uma discussão de políticas públicas. Informaçōes Econômicas, v.25, n.11, p.37-67, nov. 1995.

VARANGIS, P; THIGPEN, E.; AKIYAMA, T. Risk management prospects for Egyptian cotton. Washington: The World Bank, Jan. 1993. 26p. (Policy Research Working Paper 1077).

VARANGIS, P.; THIGPEN, E; SATYANARAYAN, S. The use of New York cotton futures contracts to hedge cotton price risk in developing countries. Washington: The World Bank, July 1994. 28p. (Policy Research Working Paper 1328). 
WILLIAMS, J.; PECK, A.; PARK, A.; ROZELLE, S. The emergence of a futures market: mungbeans on the China Zhengzhou Commodity Exchange. The Journal of Futures Markets, v.18, n.4, p.427-448, 1998.

WORKING, H. Futures trading and hedging The American Economic Review, v.43, n.3, p.314-343, 1953. 


\section{APÊNDICES}


Apêndice 1. Procedimento seqũencial para testar a presença de raiz unitária.

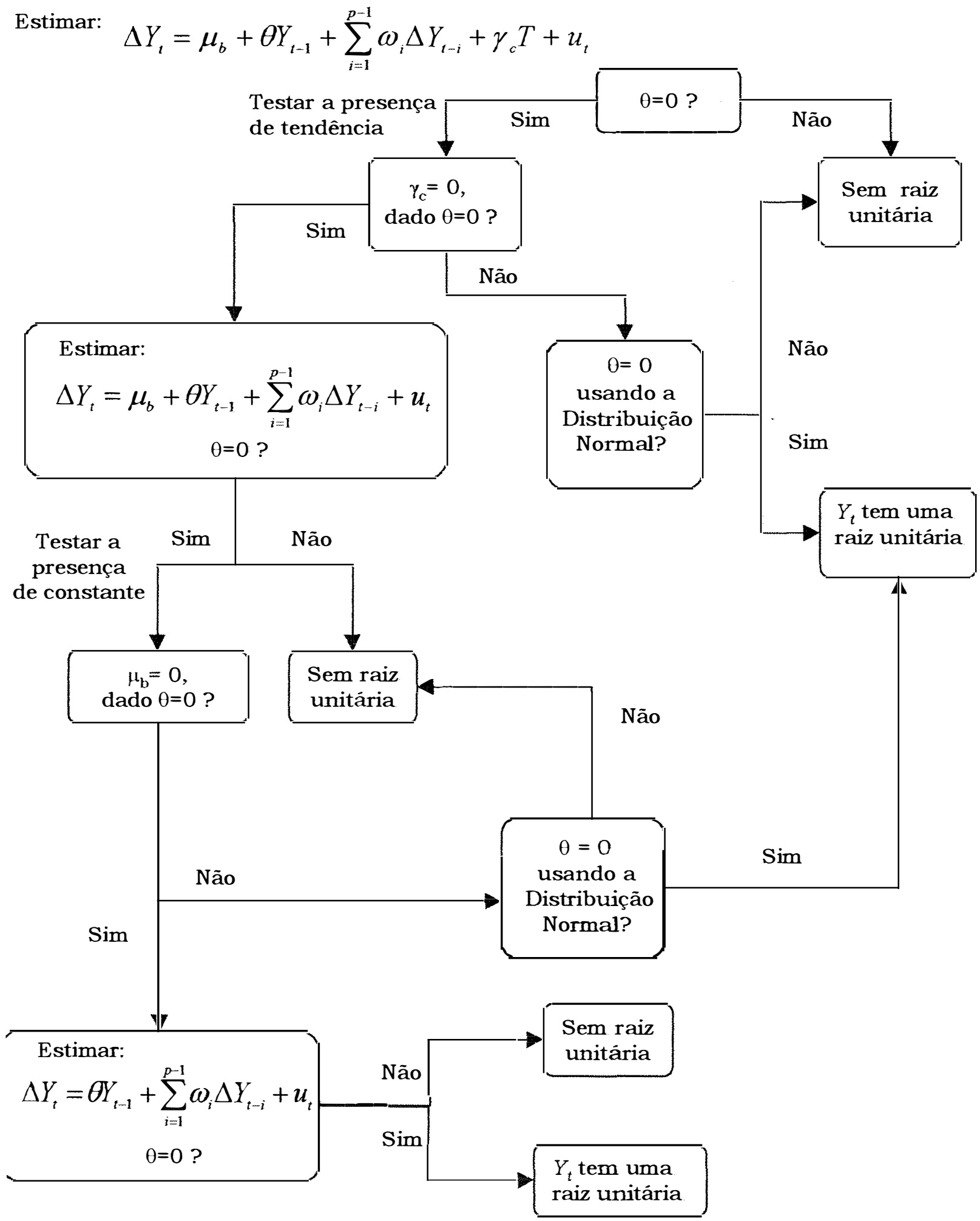

Fonte: Enders, 1995 (p. 257). 


\section{Apêndice 2}

Resultados do AIC e SC, para as séries de preços utilizadas na estimação das razões ótimas de hedge para os contratos futuros da BM\&F e NYCE, excluindo-se o ano de 1999.

Série de preços futuros BM\&F

Preços futuros NYCE

\begin{tabular}{|c|c|c|c|c|c|c|c|c|}
\hline \multirow{3}{*}{$\begin{array}{c}\text { Número } \\
\text { defasagens }\end{array}$} & \multicolumn{2}{|c|}{ Preço futuro BM\&F } & \multirow{2}{*}{\multicolumn{2}{|c|}{$\begin{array}{c}\text { Indipluma } \\
\text { Critério }\end{array}$}} & \multirow{2}{*}{\multicolumn{2}{|c|}{$\begin{array}{c}\text { Preço futuro NYCE } \\
\text { Critério }\end{array}$}} & \multirow{2}{*}{\multicolumn{2}{|c|}{$\begin{array}{c}\text { Indipluma } \\
\text { Critério }\end{array}$}} \\
\hline & \multicolumn{2}{|c|}{ Critério } & & & & & & \\
\hline & AIC & SC & AIC & SC & AIC & $\mathbf{s c}$ & AIC & SC \\
\hline 1 & $-338,86$ & $-333,57$ & $-465,13$ & $-459,84$ & $-309,56$ & $-304,16$ & $-491,51$ & $-486,11$ \\
\hline 2 & $-338,20$ & $-330,27$ & $-536,48$ & $-528,54$ & $-313,90$ & $-305,80$ & $-563,53$ & $-555,43$ \\
\hline 3 & $-336,80$ & $-326,22$ & $-535,05$ & $-524,47$ & $-311,91$ & $-301,11$ & $-561,86$ & $-551,06$ \\
\hline 4 & $-335,04$ & $-321,82$ & $-533,12$ & $-519,90$ & $-309,91$ & $-296,41$ & $-562,45$ & $-548,95$ \\
\hline 5 & $-333,72$ & $-317,85$ & $-533,53$ & $-517,66$ & $-307,91$ & $-291,71$ & $-560,90$ & $-544,70$ \\
\hline
\end{tabular}

Resultados da identificação dos elementos determinísticos e testes de raiz unitária nas séries do Indipluma ESALQ/BM\&F e preços futuros da BM\&F e NYCE em nivel, excluindo-se o ano de 1999.

\section{Séries em nivel}

\begin{tabular}{ccccc}
\hline Estatistica & $\begin{array}{c}\text { Preços } \\
\text { futuros BM\&F }\end{array}$ & $\begin{array}{c}\text { Indipluma (razão } \\
\text { otima BM\&F) }\end{array}$ & $\begin{array}{c}\text { Preços futuros } \\
\text { NYCE }\end{array}$ & $\begin{array}{c}\text { Indipluma (razão } \\
\text { ótima NYCE) }\end{array}$ \\
\hline$\tau_{\tau}$ & $\mathrm{t}=-2,13$ & $\mathrm{t}=-2,57$ & $\mathrm{t}=-1,67$ & $\mathrm{t}=-2,43$ \\
$\tau_{\beta \tau}$ & $\mathrm{t}=-1,79$ & $\mathrm{t}=-2,14$ & $\mathrm{t}=-1,30$ & $\mathrm{t}=-1,98$ \\
$\phi_{3}$ & $\mathrm{~F}=2,28$ & $\mathrm{~F}=3,54$ & $\mathrm{~F}=1,63$ & $\mathrm{~F}=3,22$ \\
$\tau_{\mu}$ & $\mathrm{t}=-1,15$ & $\mathrm{t}=-1,56$ & $\mathrm{t}=-1,25$ & $\mathrm{t}=-1,56$ \\
$\tau_{\alpha \mu}$ & $\mathrm{t}=1,14$ & $\mathrm{t}=1,54$ & $\mathrm{t}=1,24$ & $\mathrm{t}=1,54$ \\
$\phi_{1}$ & $\mathrm{~F}=0,84$ & $\mathrm{~F}=1,51$ & $\mathrm{~F}=1,16$ & $\mathrm{~F}=1,53$ \\
$\tau$ & $\mathrm{t}=-\mathbf{0 , 6 2}$ & $\mathrm{t}=-\mathbf{0 , 8 0}$ & $\mathrm{t}=-\mathbf{0 , 8 9}$ & $\mathrm{t}=-\mathbf{0 , 8 2}$
\end{tabular}

Notas: os valores criticos para as estatísticas DF são apresentados em Fuller (1996) e Dickey \& Fuller (1981). O tamanho da amostra utilizado para realização dos testes foi 250. 
Resultados dos testes de raiz unitária para as séries de preços à vista (Indipluma ESALQ/BM\&F) e futuros da BM\&F e NYCE na primeira diferença, excluindo-se o ano de 1999.

\section{Séries na primeira diferença}

\begin{tabular}{cccccc}
\hline Estatística & $\begin{array}{c}\text { Valor critico } \\
(1 \%)\end{array}$ & $\begin{array}{c}\text { Preços futuros } \\
\text { BM\&F }\end{array}$ & $\begin{array}{c}\text { Indipluma (razáo } \\
\text { ótima BM\&F) }\end{array}$ & $\begin{array}{c}\text { Preços futuros } \\
\text { NYCE }\end{array}$ & $\begin{array}{c}\text { Indipluma (razáo } \\
\text { ótima NYCE) }\end{array}$ \\
\hline$\tau$ & $-2,58$ & $\mathrm{t}=-9,08^{*}$ & $\mathrm{t}=-4,14^{*}$ & $\mathrm{t}=-8,63^{\star}$ & $\mathrm{t}=-4,36^{\star}$
\end{tabular}

Notas: os valores criticos para a estatistica $\tau$ são apresentados em Fuller (1996); o tamanho da amostra utilizado para realização dos testes foi 250 ; * valor significativo a $1 \%$.

Resultados da verificação da hipótese de mercado futuro eficiente para os preços futuros da $\mathrm{BM} \& \mathrm{FF}^{41}$, excluindo-se o ano de 1999.

\begin{tabular}{ccc}
\hline Estatistica & Hipótese nula & $\begin{array}{c}\text { Preços futuros BM\&F na 1a } \\
\text { diferença }\end{array}$ \\
\hline$\tau_{\tau}$ & $\mathrm{b}=0$ & $\mathrm{t}=-1,85$ \\
$\tau_{\beta \tau}$ & $\mathrm{a}_{1}=0$, dado $\mathrm{b}=0$ & $\mathrm{t}=-1,54$ \\
$\phi_{3}$ & $\mathrm{~b}=\mathrm{a}_{1}=0$ & $\mathrm{~F}=1,71$ \\
$\tau_{\mu}$ & $\mathrm{b}=0$ & $\mathrm{t}=-1,015$ \\
$\tau_{\alpha \mu}$ & $\mathrm{a}_{0}=0$, dado $\mathrm{b}=0$ & $\mathrm{t}=1,00$ \\
$\phi_{1}$ & $\mathrm{a} 0=\mathrm{b}=0$ & $\mathrm{~F}=0,72$ \\
$\tau$ & $\mathbf{b}=\mathbf{0}$ & $\mathbf{t}=\mathbf{- 0 , 6 7}$
\end{tabular}

Notas: os valores criticos para as estatísticas DF são apresentados em Fuller (1996) e Dickey \& Fuller (1981); o tamanho da amostra utilizado para realização dos testes foi 250 .

\footnotetext{
${ }^{41}$ Não foi realizada a verificação da hipótese de mercado futuro eficiente para a NYCE, pois a série de preços futuros dessa Bolsa comporta-se como um AR(2), já indicando um mercado não eficiente no periodo de janeiro de 1997 a dezembro de 1998. Apesar disso, foi realizada a estimação da razão ótima de hedge, supondo infinita aversão ao risco do agente $(\lambda \rightarrow \infty)$.
} 
Apêndice 3. Resultados do AIC e SC para as séries dos diferenciais entre as taxas de juros nos mercados interno e externo.

\begin{tabular}{ccccccccc} 
& \multicolumn{2}{c}{$\boldsymbol{d} \boldsymbol{d}_{\boldsymbol{I}}$ (CDB) } & \multicolumn{2}{c}{$\boldsymbol{d}_{\boldsymbol{1}}$ (FCG) } & \multicolumn{2}{c}{$\boldsymbol{d}_{\boldsymbol{2}}$ (CDB) } & \multicolumn{2}{c}{$\boldsymbol{d}$ (FCG) } \\
\hline \multirow{2}{*}{ Número de } & \multicolumn{2}{c}{ Critério } & \multicolumn{2}{c}{ Critério } & \multicolumn{2}{c}{ Critério } & \multicolumn{2}{c}{ Critério } \\
\cline { 2 - 9 } defasagens & AIC & $\mathbf{S C}$ & AIC & SC & AIC & SC & AIC & SC \\
\hline 1 & $\mathbf{2 8 0 , 6 2}$ & $\mathbf{2 8 3 , 7 9}$ & $\mathbf{2 9 4 , 2 0}$ & $\mathbf{2 9 7 , 3 7}$ & 270,86 & 274,03 & 291,36 & 294,53 \\
2 & 282,37 & 287,12 & 295,67 & 300,42 & 265,70 & 270,45 & $\mathbf{2 8 3 , 0 6}$ & $\mathbf{2 8 7 , 8 1}$ \\
3 & 282,69 & 289,02 & 297,13 & 303,47 & $\mathbf{2 6 4 , 4 4}$ & $\mathbf{2 7 0 , 7 9}$ & 284,03 & 290,37 \\
4 & 284,44 & 292,35 & 298,64 & 306,56 & 266,00 & 273,92 & 285,76 & 293,68 \\
5 & 286,22 & 295,72 & 300,39 & 309,90 & 267,11 & 276,61 & 287,66 & 297,16 \\
6 & 288,21 & 299,29 & 302,37 & 313,46 & 269,11 & 280,20 & 289,52 & 300,60 \\
7 & 290,18 & 302,84 & 304,25 & 316,92 & 269,77 & 282,44 & 291,35 & 304,02 \\
8 & 292,17 & 306,42 & 306,08 & 320,33 & 269,77 & 284,02 & 292,44 & 306,69 \\
9 & 294,10 & 309,93 & 308,05 & 323,88 & 271,20 & 287,03 & 293,74 & 309,58 \\
10 & 294,94 & 312,36 & 308,72 & 326,14 & 269,76 & 287,18 & 291,36 & 308,78 \\
11 & 296,71 & 315,72 & 308,32 & 327,32 & 269,16 & 288,16 & 288,46 & 307,46 \\
12 & 296,31 & 316,89 & 307,00 & 327,59 & 269,23 & 289,82 & 290,44 & 311,03
\end{tabular}

Notas: $d_{1}$ é a diferença entre a taxa de juros no mercado interno (CDB ou taxa de financiamento do capital de giro) descontada a variaçāo cambial e o custo de captação de recursos externos; $d_{2}$ é a diferença entre a taxa real de juros no mercado interno (CDB ou taxa de financiamento do capital de giro) e o custo de captação de recursos externos; FCG refere-se à taxa de Financiamento do Capital de Giro. 
Apêndice 4. Resultados do AIC e SC para as séries das importações financiadas de algodão em pluma.

\begin{tabular}{|c|c|c|c|c|c|c|c|c|}
\hline & \multirow{2}{*}{\multicolumn{2}{|c|}{$\begin{array}{c}\text { Até } 180 \text { dias } \\
\text { Critério }\end{array}$}} & \multirow{2}{*}{\multicolumn{2}{|c|}{$\begin{array}{c}\text { De } 181 \text { a } 360 \text { dias } \\
\text { Critério }\end{array}$}} & \multirow{2}{*}{\multicolumn{2}{|c|}{$\begin{array}{c}\text { Acima de } 360 \text { dias } \\
\text { Critério }\end{array}$}} & \multirow{2}{*}{\multicolumn{2}{|c|}{$\begin{array}{c}\text { Imp. Financ. Totais } \\
\text { Critério }\end{array}$}} \\
\hline & & & & & & & & \\
\hline & \multirow{2}{*}{1031,84} & \multirow{2}{*}{$\begin{array}{c}\text { SC } \\
1034,64\end{array}$} & \multirow{2}{*}{$\begin{array}{c}\text { AIC } \\
970,90\end{array}$} & \multirow{2}{*}{$\begin{array}{c}\text { SC } \\
973,71\end{array}$} & \multirow{2}{*}{$\begin{array}{c}\text { AIC } \\
1061,61\end{array}$} & \multirow{2}{*}{$\begin{array}{c}\text { SC } \\
1064,41\end{array}$} & \multirow{2}{*}{$\begin{array}{c}\text { AIC } \\
1076,38\end{array}$} & \multirow{2}{*}{$\begin{array}{c}\text { SC } \\
1079,19\end{array}$} \\
\hline $\begin{array}{c}\text { Número de } \\
\text { defasagens } \\
1\end{array}$ & & & & & & & & \\
\hline 2 & 1032,40 & 1036,60 & 972,83 & 977,04 & 1062,62 & 1066,83 & 1075,34 & 1079,54 \\
\hline 3 & 1034,27 & 1039,88 & 974,49 & 980,09 & 1064,13 & 1069,73 & 1077,33 & 1082,94 \\
\hline 4 & 1035,67 & 1042,67 & 975,86 & 982,87 & 1065,93 & 1072,93 & 1079,32 & 1086,33 \\
\hline 5 & 1036,19 & 1044,60 & 977,06 & 985,46 & 1065,13 & 1073,54 & 1077,50 & 1085,90 \\
\hline 6 & 1036,92 & 1046,73 & 978,42 & 988,23 & 1067,08 & 1076,88 & 1079,12 & 1088,92 \\
\hline 7 & 1037,44 & 1048,65 & 972,84 & 984,05 & 1066,74 & 1077,95 & 1080,30 & 1091,51 \\
\hline 8 & 1035,46 & 1048,07 & 966,99 & 979,60 & 1068,74 & 1081,35 & 1082,17 & 1094,78 \\
\hline 9 & 1028,17 & 1042,18 & 955,03 & 969,04 & 1068,74 & 1082,76 & 1064,90 & 1078,92 \\
\hline 10 & 1029,90 & 1045,31 & 957,02 & 972,43 & 1069,64 & 1085,05 & 1066,70 & 1082,11 \\
\hline 11 & 1029,59 & 1046,40 & 957,52 & 974,33 & 1071,60 & 1088,41 & 1068,21 & 1085,03 \\
\hline 12 & 1031,46 & 1049,68 & 958,82 & 977,04 & 1073,20 & 1091,41 & 1070,16 & 1088,38 \\
\hline 13 & 1033,07 & 1052,68 & 960,62 & 980,23 & 1073,80 & 1093,41 & 1072,05 & 1091,66 \\
\hline 14 & 1032,92 & 1053,94 & 962,55 & 983,57 & 1074,68 & 1095,70 & 1067,24 & 1088,25 \\
\hline 15 & 1028,86 & 1051,28 & 964,55 & 986,97 & 1076,63 & 1099,04 & 1069,23 & 1091,65 \\
\hline 16 & 1024,31 & 1048,13 & 963,35 & 987,17 & 1078,28 & 1102,10 & 1070,36 & 1094,18 \\
\hline 17 & 1025,47 & 1050,69 & 964,45 & 989,67 & 1080,27 & 1105,49 & 1066,71 & 1091,93 \\
\hline 18 & 1024,20 & 1050,82 & 965,82 & 992,44 & 1080,97 & 1107,59 & 1066,28 & 1092,91 \\
\hline
\end{tabular}

Notas: todas as séries referem-se ao valor CIF das importações financiadas de algodão em pluma; as Importações Financiadas Totais (Imp. Financ. Totais) correspondem à soma das importações financiadas sob todas as formas de pagamento. 
Apêndice 5. Testes de raiz unitária com mudança estrutural ${ }^{42}$

$\mathrm{Na}$ realização dos testes de raiz unitária, deve-se tomar especial cuidado se há suspeitas de que tenha ocorrido uma mudança estrutural. Quando há quebras estruturais, as estatísticas de Dickey e Fuller e os testes estatísticos de Phillips-Perron são viesadas no sentido de não rejeitar a hipótese de raiz unitária.

Para testar a presença de raiz unitária quando há mudança estrutural, pode-se dividir a amostra em duas partes e usar os testes de Dickey-Fuller em cada uma delas. Entretanto, o problema com esse procedimento é que diminui-se os graus de liberdade em cada uma das regressões resultantes. Por essa razão, é preferivel ter um único teste, baseado na amostra toda.

Perron (1989) desenvolveu um procedimento formal para testar a presença de raiz unitária quando há uma mudança estrutural no momento $\mathrm{t}=\tau+1$. Sob a hipótese nula tem-se uma mudança no nível de um processo com raiz unitária e sob a hipótese alternativa tem-se uma mudança no intercepto de um processo com tendência determinística. Formalmente, essas hipóteses são representadas por (32):

$$
\begin{aligned}
& H_{0}: y_{t}=a_{0}+y_{t-1}+\mu_{1} D_{P}+e_{t} \\
& H_{A}: y_{t}=a_{0}+a_{2} t+\mu_{2} D_{l}+e_{t}
\end{aligned}
$$

$D_{P}=$ variável dummy de pulso que assume valor um se $\mathrm{t}=\tau+1$ e zero caso contrário;

$D_{L}=$ variável dummy de nível que assume valor um se $\mathrm{t}>\tau$ e zero caso contrário.

${ }^{42}$ Esta seção baseia-se em Enders (1995). 
Sob a hipótese nula, $y_{t}$ é um processo com raiz unitária com um salto no nivel da seqüência no momento $t=\tau+1$. Sob a hipótese alternativa, $y_{t}$ é um processo com tendência determinística, que apresenta um salto no intercepto.

A técnica de Perron (1989) consiste em eliminar a tendência da série, estimando-se a hipótese alternativa $\left(H_{A}\right)$ em (32). Utilizando-se os resíduos daquela regressão $\left(\operatorname{Res}_{t}\right)$, estima-se então a equação (33)

$$
\operatorname{Re} s_{t}=a_{1} \operatorname{Re} s_{t-1}+e_{t}
$$

É necessário verificar se os resíduos da equação (33) são não correlacionados. Se existir autocorrelação serial, deve-se utilizar a forma aumentada da regressão, representada pela equação (34):

$$
\operatorname{Re} s_{t}=a_{1} \operatorname{Re} s_{t-1}+\sum_{i=1}^{n-1} \beta_{i} \Delta \operatorname{Re} s_{t-i}+e_{t}
$$

Sob a hipótese nula de raiz unitária, o valor teórico de $a_{1}$ é um. Perron (1989) mostra em seu estudo, que quando os resíduos são independentes e identicamente distribuídos (iid), a distribuição de $a_{1}$ depende da proporção de observações que ocorrem antes da quebra.

Assim, o valor da estatística $t$ referente à hipótese nula $a_{1}=1$ deve ser comparado aos valores críticos calculados por Perron (1989), considerando-se a proporção de observações que ocorrem antes da quebra, denotada por $\lambda=\frac{\tau}{T}$, onde $T$ é o número total de observaçōes e $\tau$ é o número de observaçōes antes da quebra. 
Apêndice 6. Lista de algumas Resoluções e Circulares editadas pelo Banco Central do Brasil entre 1996 e 1999, que afetaram o regulamento das importações e aspectos referentes à Resolução no 63/67.

Circular no 002660 de 08/02/1996 - Estabelece as modalidades de aplicação de recursos captados ao amparo da Resolução n. 63/67.

Circular nº 002661 de 08/02/1996 - Estabelece prazos minimos para a contratação, renovação e prorrogação de operações de empréstimos externos.

Circular $\mathrm{n}^{\circ} 002670$ de 01/03/1996 - Estabelece as modalidades de aplicação de recursos captados ao amparo da Resolução no 63/67.

Circular no 002726 de 31/10/1996 - Estabelece as modalidades de aplicação de recursos captados ao amparo da Resolução n 63/67.

Circular $\mathrm{n}^{\mathrm{o}} 002730$ de 13/12/1996 - Divulga o regulamento de Importação e promove outras alterações.

Circular $\mathrm{n}^{\text {o }} 002747$ de 15/07/1997 - Altera o regulamento que rege o pagamento das importações brasileiras a prazo de até 360 dias.

Circular no 002749 de 03/04/1997 - Altera o regulamento que rege o pagamento das importações brasileiras a prazo de até 360 dias.

Circular $\mathrm{n}^{\mathrm{o}} 002753$ de 30/04/1997 - Altera o regulamento de importação, instituído pela Circular n² 2730, de 13/12/1996.

Circular $n^{\circ} 002762$ de 24/06/1997 - Altera o regulamento que rege o pagamento das importações brasileiras a prazo de até 360 dias.

Circular $\mathrm{n}^{\circ} 002778$ de 13/10/1997 - Altera o regulamento que rege o pagamento das importações brasileiras a prazo de até 360 dias.

Circular $\mathrm{n}^{\circ} 002805$ de 11/02/1998 - Altera o regulamento que rege o pagamento das importações brasileiras a prazo de até 360 dias.

Circular nº 002807 de 26/02/1998 - Estabelece prazos minimos para a contratação, renovação e prorrogação de operações de empréstimos externos.

Circular no 002834 de 24/06/1998 - Estabelece prazos minimos para a con ratação, renovação e prorrogação de operações de empréstimos externos.

Circular $\mathrm{n}^{\circ} 002845$ de 21/10/1998 - Altera o regulamento que rege o pagamento das importações brasileiras a prazo de até 360 dias. 
Circular $\mathrm{n}^{\circ} 002848$ de 11/11/1998 - Altera e consolida as normas aplicáveis a repasses interbancários de recursos captados nos termos da Resolução $n^{0}$ 63/67.

Circular $\mathrm{n}^{\circ} 002850$ de 30/11/1998 - Estabelece prazos mínimos para a contratação, renovação e prorrogação de operações de empréstimos externos.

Circular $\mathrm{n}^{\circ} 002859$ de 27/01/1999 - Estabelece prazos mínimos para a contratação, renovação e prorrogação de operações de empréstimos externos.

Circular $n^{\circ} 002864$ de 24/02/1999 - Altera o regulamento que rege o pagamento das importações brasileiras a prazo de até 360 dias.

Circular $n^{\circ} 002876$ de 17/03/1999 - Altera o regulamento que rege o pagamento das importações brasileiras a prazo de até 360 dias.

Circular $n^{0} 002882$ de 22/04/1999 - Altera e consolida as normas aplicáveis a repasses interbancários de recursos captados nos termos da resolução $\mathrm{n}^{\circ} 63 / 67$.

Circular $n^{\circ} 002898$ de 23/06/1999 - Altera o regulamento que rege o pagamento das importações brasileiras a prazo de até 360 dias.

Circular $\mathrm{n}^{\circ} 002948$ de 28/10/1999 - Altera o Regulamento de Importação, dispensando a exigência de contratação prévia de câmbio, relativa a DIs registradas a partir de 30/10/1999, inclusive.

Resolução $\mathrm{n}^{\circ} 002483$ de 26/03/1998 - Altera e consolida regulamentação acerca da captação de recursos no mercado externo para concessão de empréstimos ou financiamentos a atividades rurais $e$ agroindustriais.

Resolução no 0025000 de 28/05/1998 - Altera a regulamentação acerca da captação de recursos no mercado externo para concessão de empréstimos ou financiamentos a atividades rurais e agroindustriais, de que trata a Resolução nº 2483 de 26/03/1998. 
Apêndice 7. Resultados do AIC e SC para as séries de preço do algodão em pluma no atacado em São Paulo e Cotlook $A$.

\begin{tabular}{ccccc} 
& \multicolumn{2}{c}{$\begin{array}{c}\text { Série de preços do } \\
\text { Pluma no atacado em Sáo Paulo }\end{array}$} & \multicolumn{2}{c}{ Cotlook A Index } \\
\hline Número de & \multicolumn{2}{c}{ Critério } & \multicolumn{2}{c}{ Critério } \\
\cline { 2 - 5 } defasagens & AIC & SC & AIC & SC \\
\hline 1 & 21,75 & $\mathbf{2 7 , 3 2}$ & $-126,61$ & $-121,03$ \\
2 & 21,09 & 29,45 & $-\mathbf{1 6 1 , 5 6}$ & $\mathbf{- 1 5 3 , 2 0}$ \\
3 & 21,12 & 32,27 & $-160,40$ & $-149,25$ \\
4 & 22,20 & 36,14 & $-158,40$ & $-144,46$ \\
5 & $\mathbf{2 1 , 0 5}$ & 37,77 & $-156,48$ & $-139,76$ \\
6 & 23,05 & 42,56 & $-157,28$ & $-137,77$ \\
7 & 22,69 & 44,99 & $-155,99$ & $-133,69$ \\
8 & 22,52 & 47,60 & $-157,32$ & $-132,23$ \\
9 & 24,00 & 51,87 & $-156,16$ & $-128,29$ \\
10 & 25,99 & 56,65 & $-154,62$ & $-123,96$ \\
11 & 27,77 & 61,22 & $-156,60$ & $-123,15$ \\
12 & 29,74 & 65,98 & $-154,63$ & $-118,39$ \\
13 & 30,79 & 69,82 & $-153,68$ & $-114,65$ \\
14 & 32,65 & 74,46 & $-151,77$ & $-109,96$ \\
15 & 34,13 & 78,73 & $-149,95$ & $-105,35$ \\
16 & 35,60 & 82,98 & $-148,04$ & $-100,65$ \\
17 & 37,47 & 87,65 & $-146,91$ & $-96,73$ \\
18 & 38,97 & 91,93 & $-145,08$ & $-92,12$ \\
19 & 38,67 & 94,42 & $-143,14$ & $-87,39$ \\
20 & 38,60 & 97,14 & $-142,04$ & $-83,51$ \\
21 & 40,51 & 101,84 & $-142,39$ & $-81,07$ \\
22 & 41,67 & 105,78 & $-142,81$ & $-78,69$ \\
23 & 43,22 & 110,12 & $-140,83$ & $-73,93$ \\
24 & 44,30 & 113,98 & $-141,54$ & $-71,85$ \\
\hline & & & &
\end{tabular}




\section{Apêndice 8}

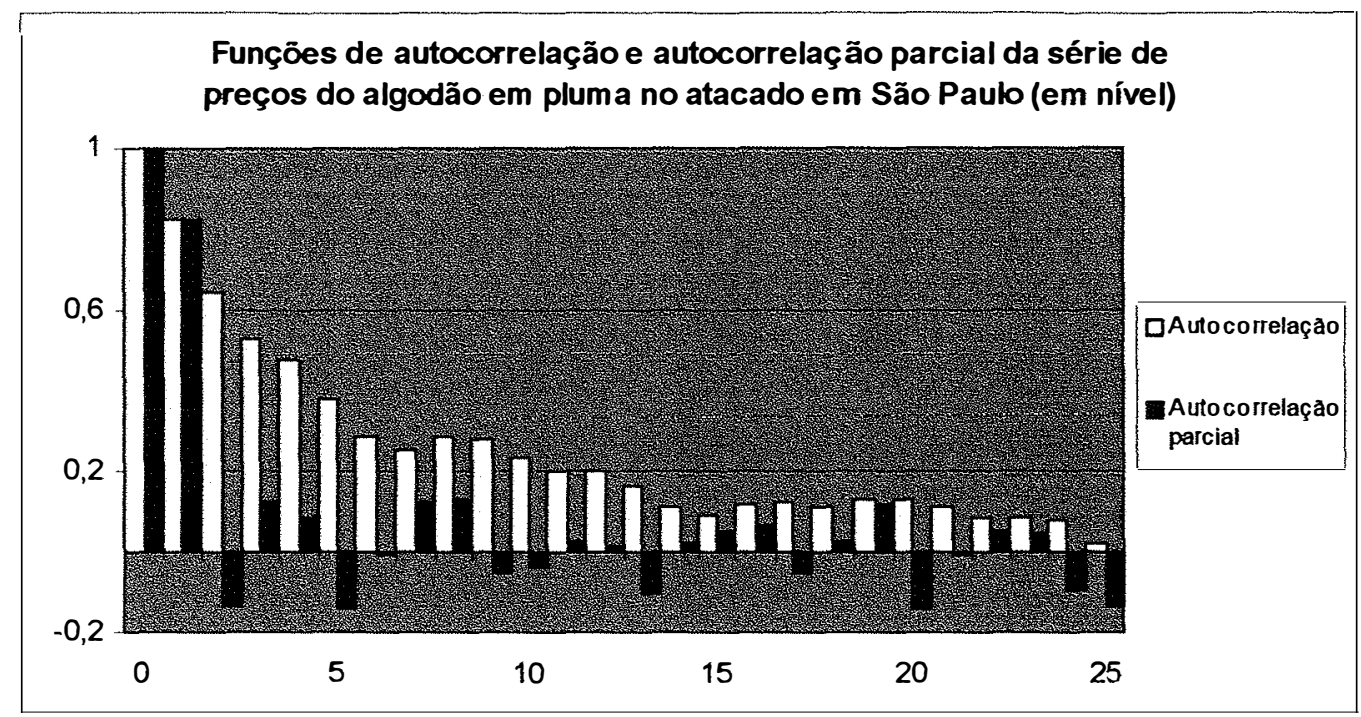

Intervalo de confiança $=0,1667$

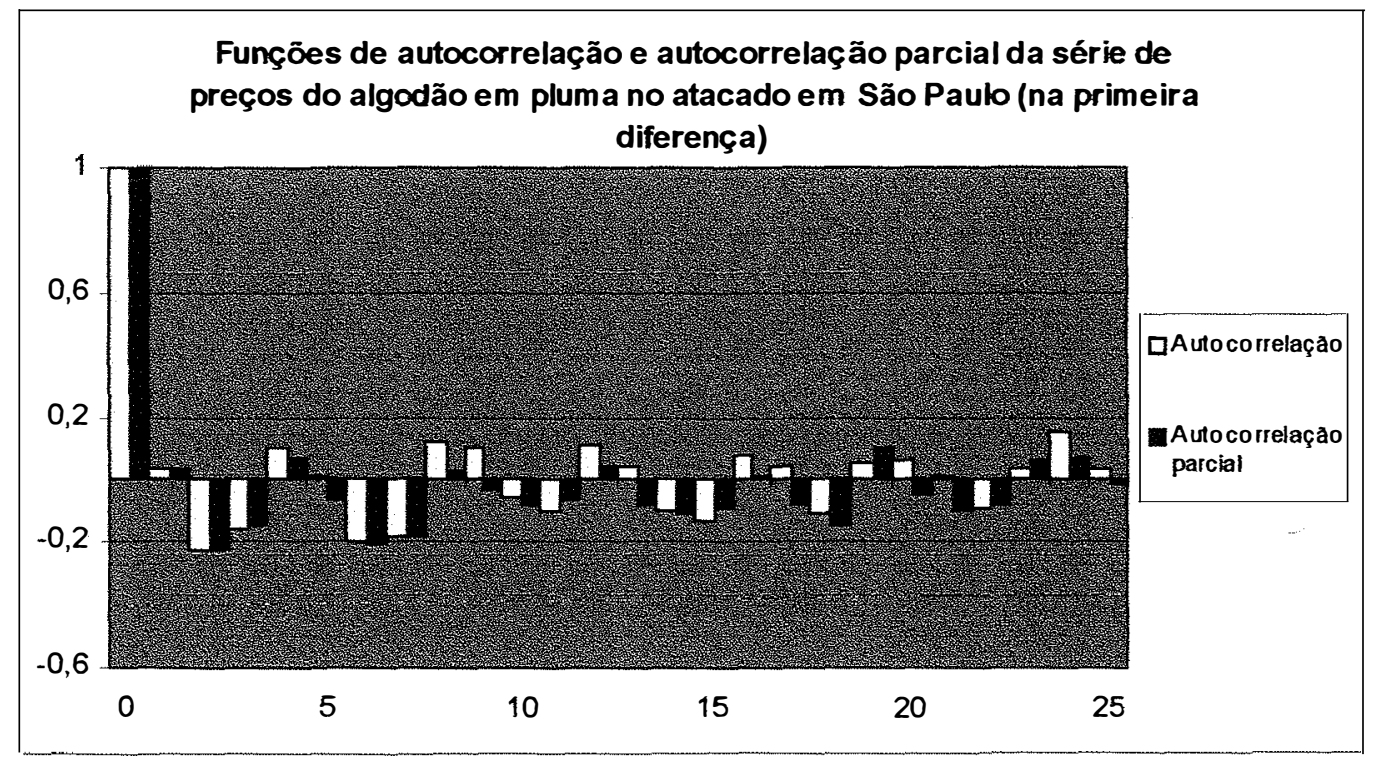

Intervalo de confiança $=0,1673$ 


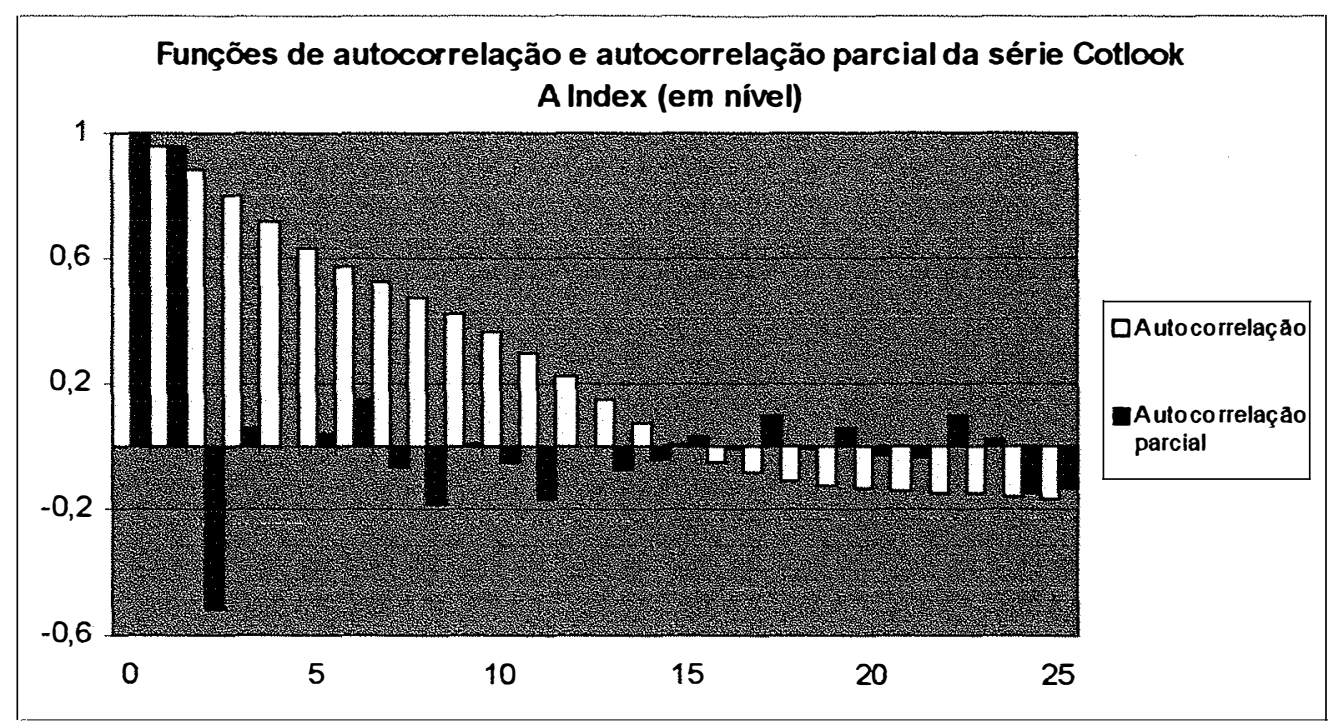

Intervalo de confiança $=0,1667$

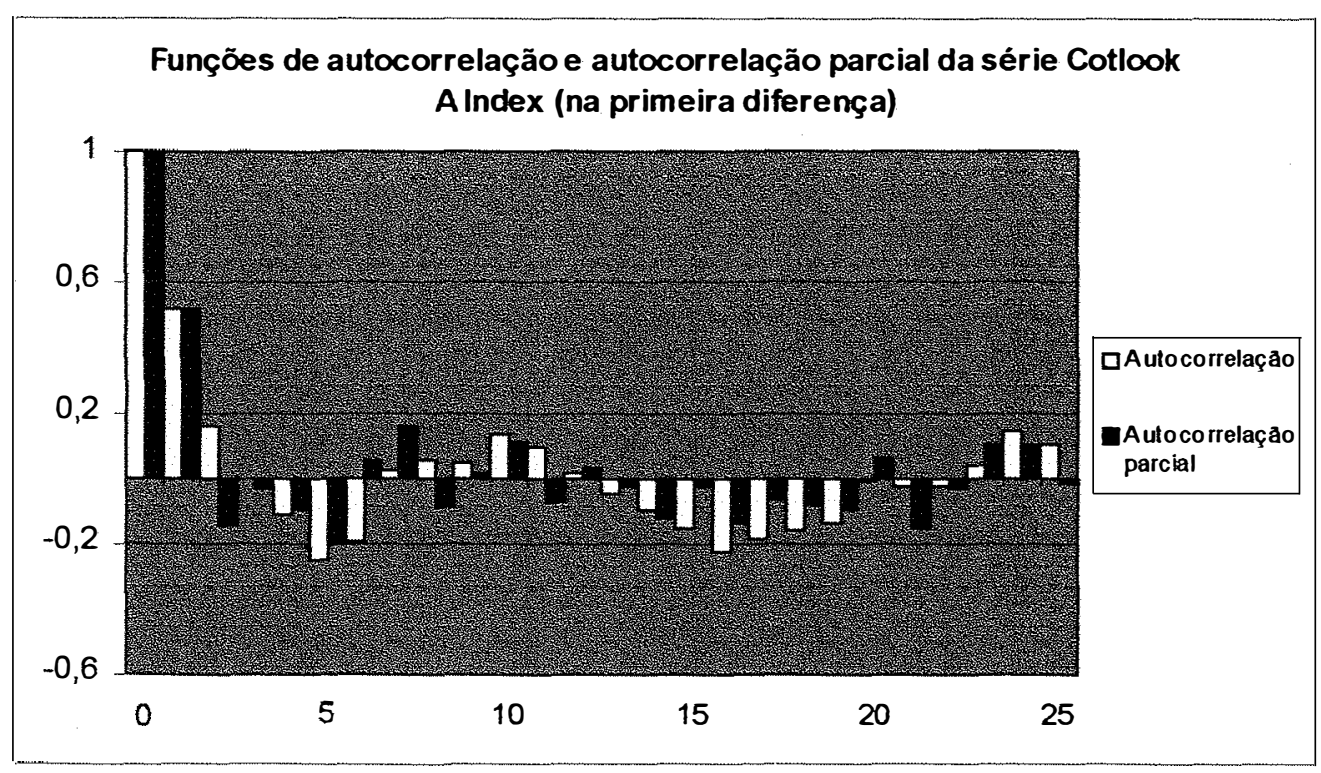

Intervalo de confiança $=0,1673$ 